\title{
Re-examination of the quartz artefacts from Scord of Brouster: a lithic assemblage from Shetland and its Neolithic context
}

\author{
by Torben Bjarke Ballin
}

Lithic Research, Banknock Cottage, Denny, Stirlingshire FK6 5NA

Scottish Archaeological Internet Report 17, 2005 www.sair.org.uk 
Published by the Society of Antiquaries of Scotland, www.socantscot.org with Historic Scotland, www.historic-scotland.gov.uk and the Council for British Archaeology, www.britarch.ac.uk

Editor Debra Barrie

Produced by Archetype Information Technology Ltd, www.archetype-it.com

ISBN: 0903903865

ISSN: $1473-3803$

Requests for permission to reproduce material from a $S A I R$ report should be sent to the Director of the Society of Antiquaries of Scotland, as well as to the author, illustrator, photographer or other copyright holder.

Copyright in any of the Scottish Archaeological Internet Reports series rests with the SAIR Consortium and the individual authors.

The maps are reproduced from Ordnance Survey material with the permission of Ordnance Survey on behalf of The Controller of Her Majesty's Stationery Office. CCrown copyright 2001. Any unauthorized reproduction infringes Crown copyright and may lead to prosecution or civil proceedings. Historic Scotland Licence No GD 03032G, 2002.

The consent does not extend to copying for general distribution, advertising or promotional purposes, the creation of new collective works or resale. 


\section{Contents}

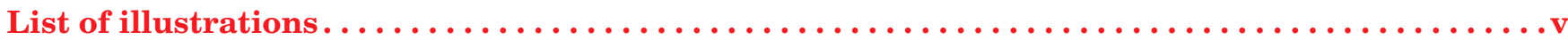

List of tables $\ldots \ldots \ldots \ldots \ldots \ldots \ldots \ldots \ldots \ldots \ldots \ldots \ldots \ldots \ldots \ldots \ldots \ldots \ldots \ldots \ldots \ldots \ldots \ldots$

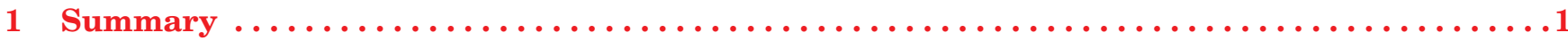

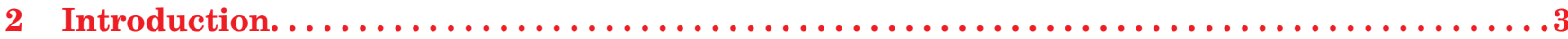

3 The Assemblage. $\ldots \ldots \ldots \ldots \ldots \ldots \ldots \ldots \ldots \ldots \ldots \ldots \ldots \ldots \ldots \ldots \ldots \ldots \ldots \ldots \ldots \ldots \ldots \ldots$

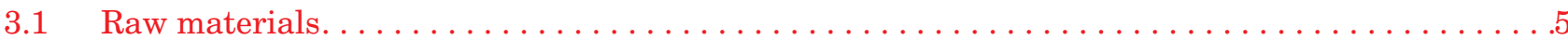

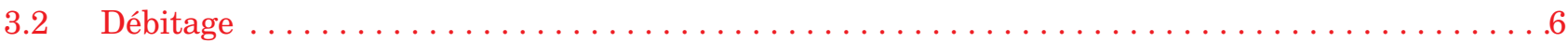

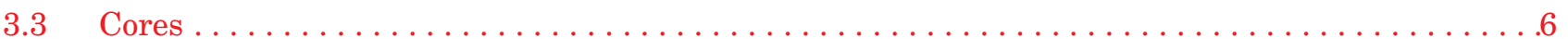

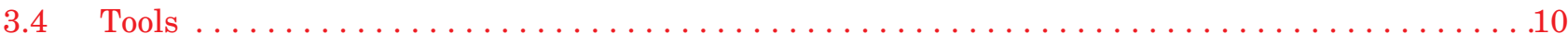

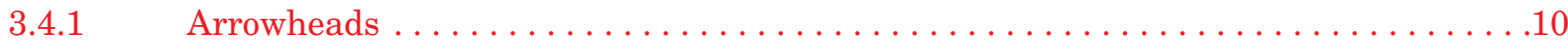

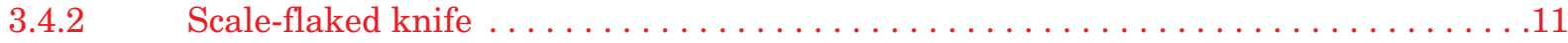

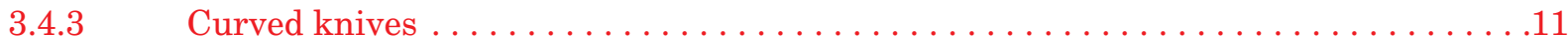

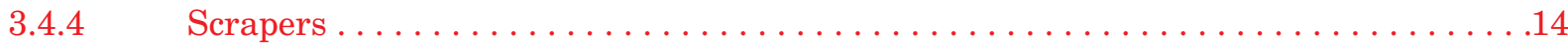

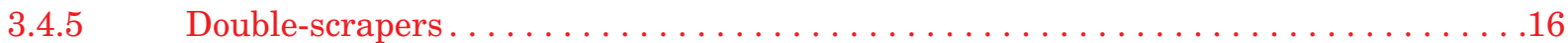

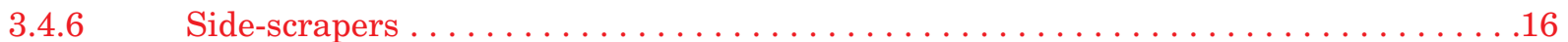

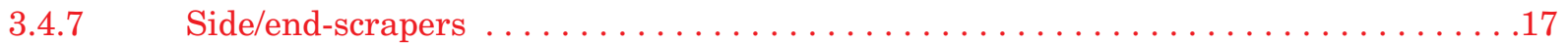

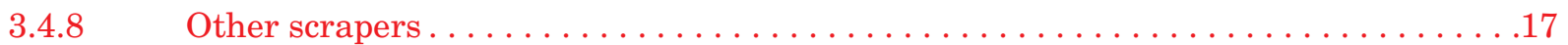

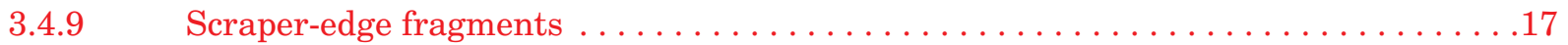

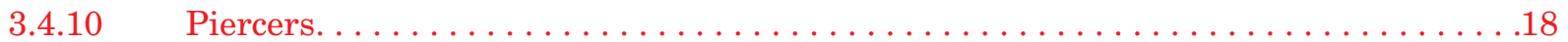

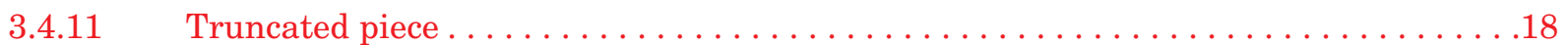

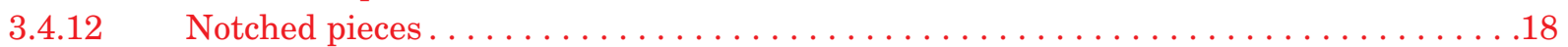

3.4.13 Denticulated pieces . . . . . . . . . . . . . . . . . . . . . . . . . . . .

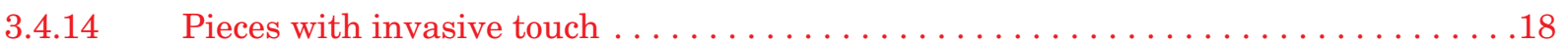

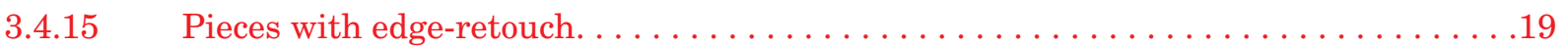

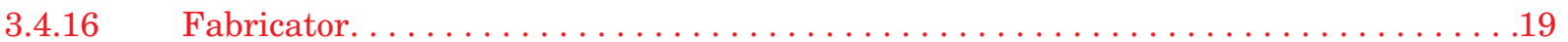

3.4.17 Hammerstones. . . . . . . . . . . . . . . . . . . . . . . . . . . . . . . . . . . . . . .19

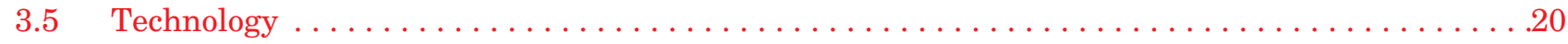

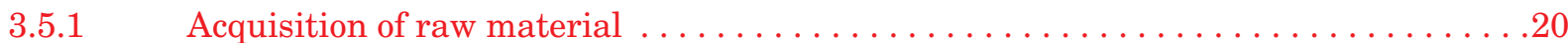

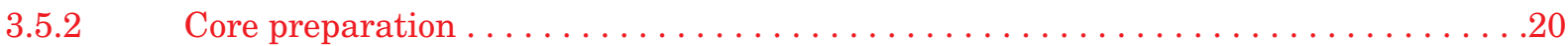

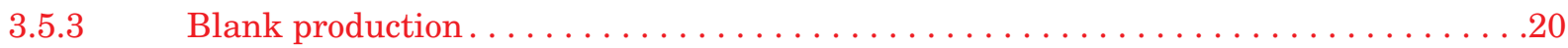

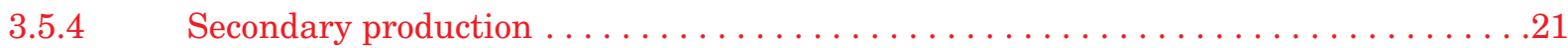

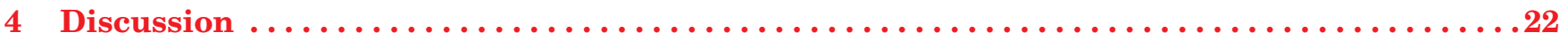

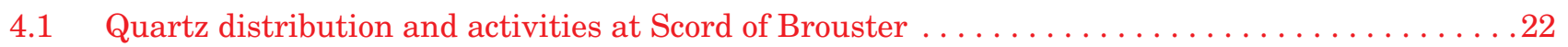

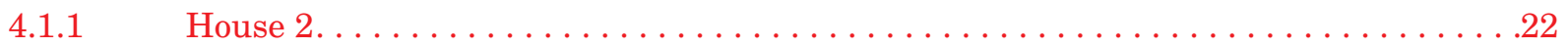

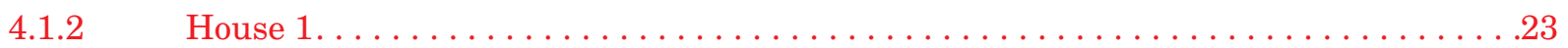

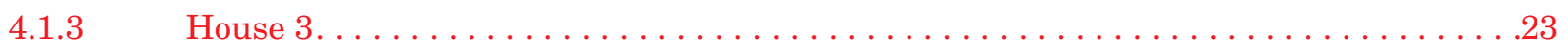

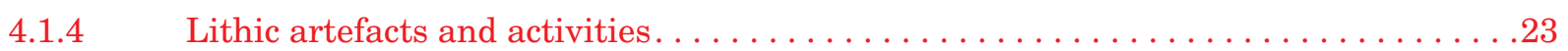

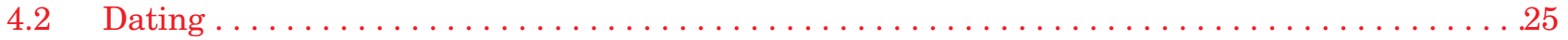

4.3 The quartz assemblage from Scord of Brouster compared with other Neolithic

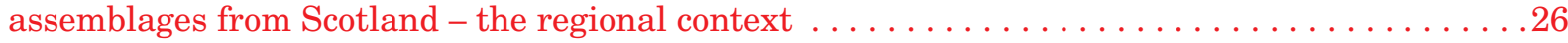

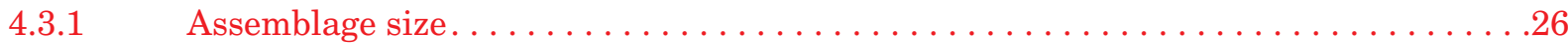




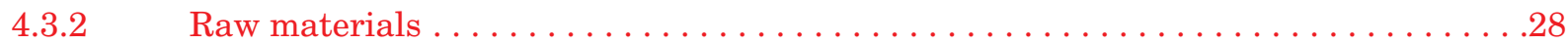

4.3.3 General artefact size . . . . . . . . . . . . . . . . . . . . . . . . . . . . . . .30

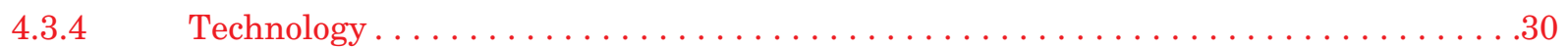

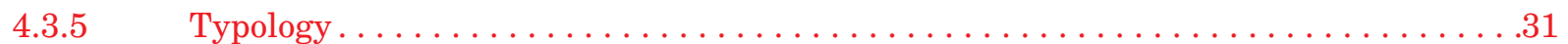

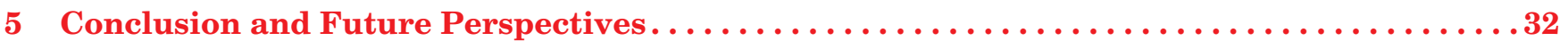

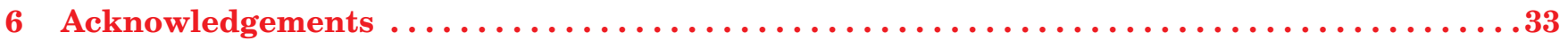

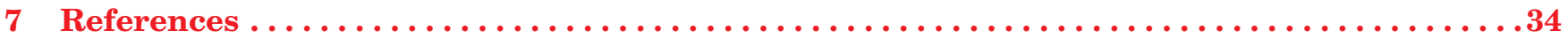




\section{List of illustrations}

Location maps (Whittle 1986, fig 1 ) . . . . . . . . . . . . . . . . . . . . . . . .

The distribution of débitage on chips, flakes and indeterminate pieces in sieved and unsieved Norwegian assemblages (Ballin 1999b, 103). In unsieved assemblages the chip ratio varies between $c 0$ and $10 \%$, and in sieved assemblages between $c 30$ and $55 \% \ldots \ldots 7$ The dimensions of all single-platform cores (incl fragmented specimens) $\ldots \ldots \ldots \ldots \ldots \ldots 7$

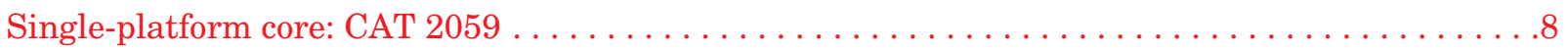

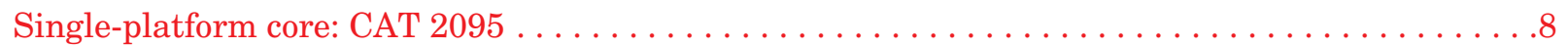

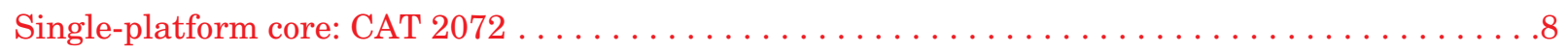

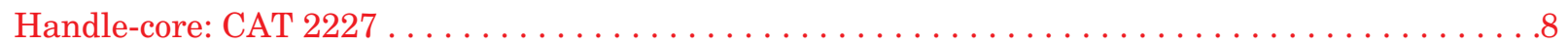

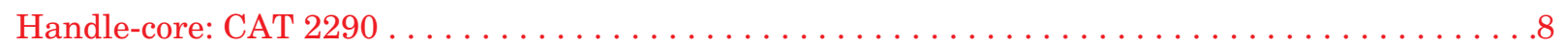

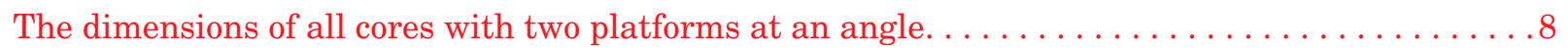

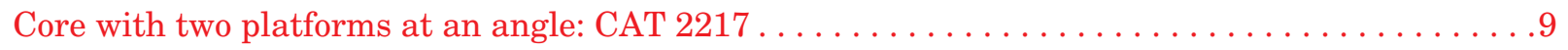

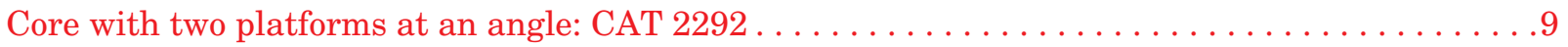

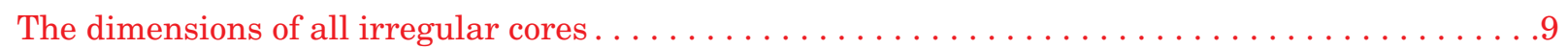

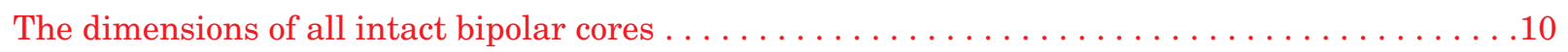

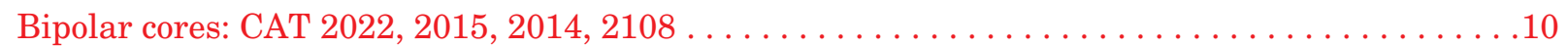

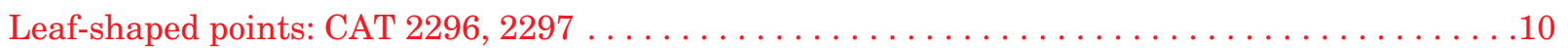

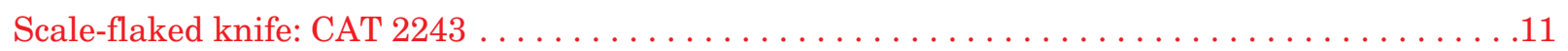

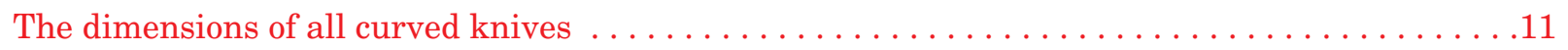

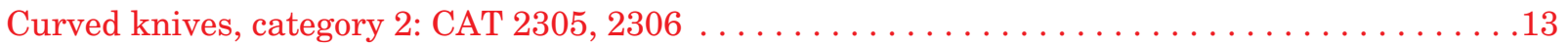

Curved knives, category 3: CAT 2298, 2299, 2302, $2303 \ldots \ldots \ldots \ldots \ldots \ldots \ldots \ldots \ldots \ldots \ldots$

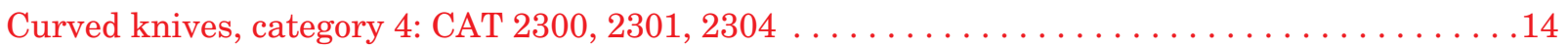

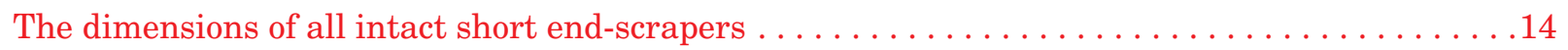

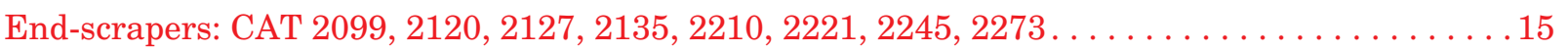

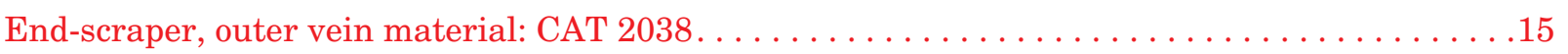

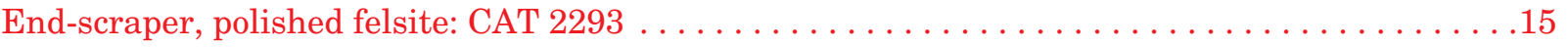

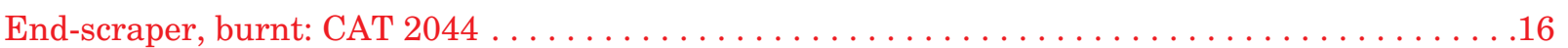

Scraper-edge angles of all short end-scrapers. For comparison, the edge angles of

the scrapers from Bayanne, Yell (Ballin, forthcoming d), are shown (curve) $\ldots \ldots \ldots \ldots \ldots \ldots$

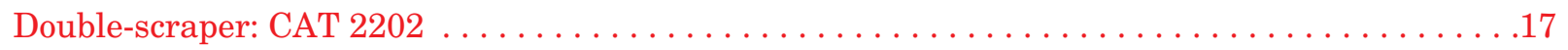

Side-scrapers: CAT 2128, 2295; and side/end-scrapers: CAT 2204, $2288 \ldots \ldots \ldots \ldots \ldots \ldots \ldots 17$

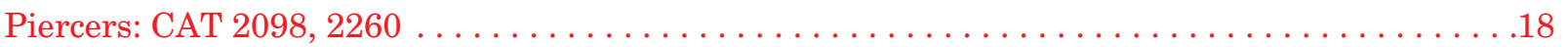

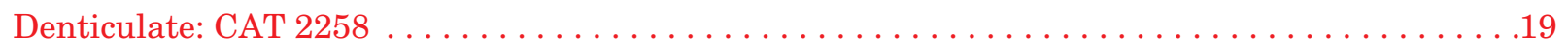

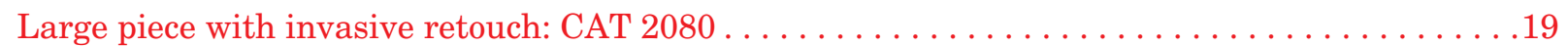

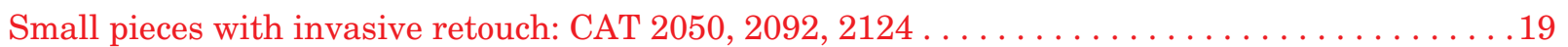

House 2 . The distribution of quartz flakes from west to east. . . . . . . . . . . . . . . 22

Radiocarbon dates; the dates were calibrated by the author using OxCal v3.8 (95.4\% probability).

For comparison, the dates from Camster Long have been inserted in the lower right corner. . . 27 The lengths of single-platform cores, short end-scrapers and bipolar cores from representative Mesolithic, Neolithic and Bronze Age assemblages (see Table 5) . . . . . . . . 29 


\section{List of tables}

Lithics - general artefact list (if the raw material of a type is not specified, all pieces are in quartz); two short end-scrapers in sandstone are described as part of the Scord of Brouster monograph's chapter on stone tools (Rees 1986, 84-5) . . . . . . . . . . . .4 The percussion techniques applied to detach the tool blanks $\ldots \ldots \ldots \ldots$

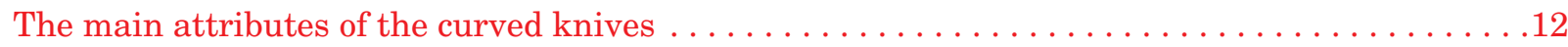
Houses 1 and 2 : the proportions of the main tool categories $\ldots \ldots \ldots \ldots \ldots \ldots \ldots \ldots$ Comparison between the average dimensions of the most common quartz types from Mesolithic, Neolithic, Early Bronze Age and Later Bronze Age assemblages . . . . . . . . . . . . 26 The general characteristics of Neolithic assemblages from the two main raw material provinces of Scotland. The province of the west coast of the Scottish mainland/ Southern Hebrides constitutes a hybrid form of these two 


\section{Summary}

In the late $1970 \mathrm{~s}$, a substantial quartz assemblage was recovered from the Neolithic settlement at Scord of Brouster, Shetland. At the time, bipolar technique (which is responsible for a substantial proportion of the assemblage), as well as quartz technology in general, were poorly understood, and it was not possible to fully make use of the assemblage in the interpretation of the site, the region, or the period.
With our expanded understanding of bipolar approaches and quartz technology, this is now possible, and, in the present paper, the assemblage is re-examined, re-classified and re-interpreted. The quartz assemblage is used to gain a deeper insight into the site itself, and its lithic component and a first sketch of the territorial structure of Neolithic Scotland is presented. 


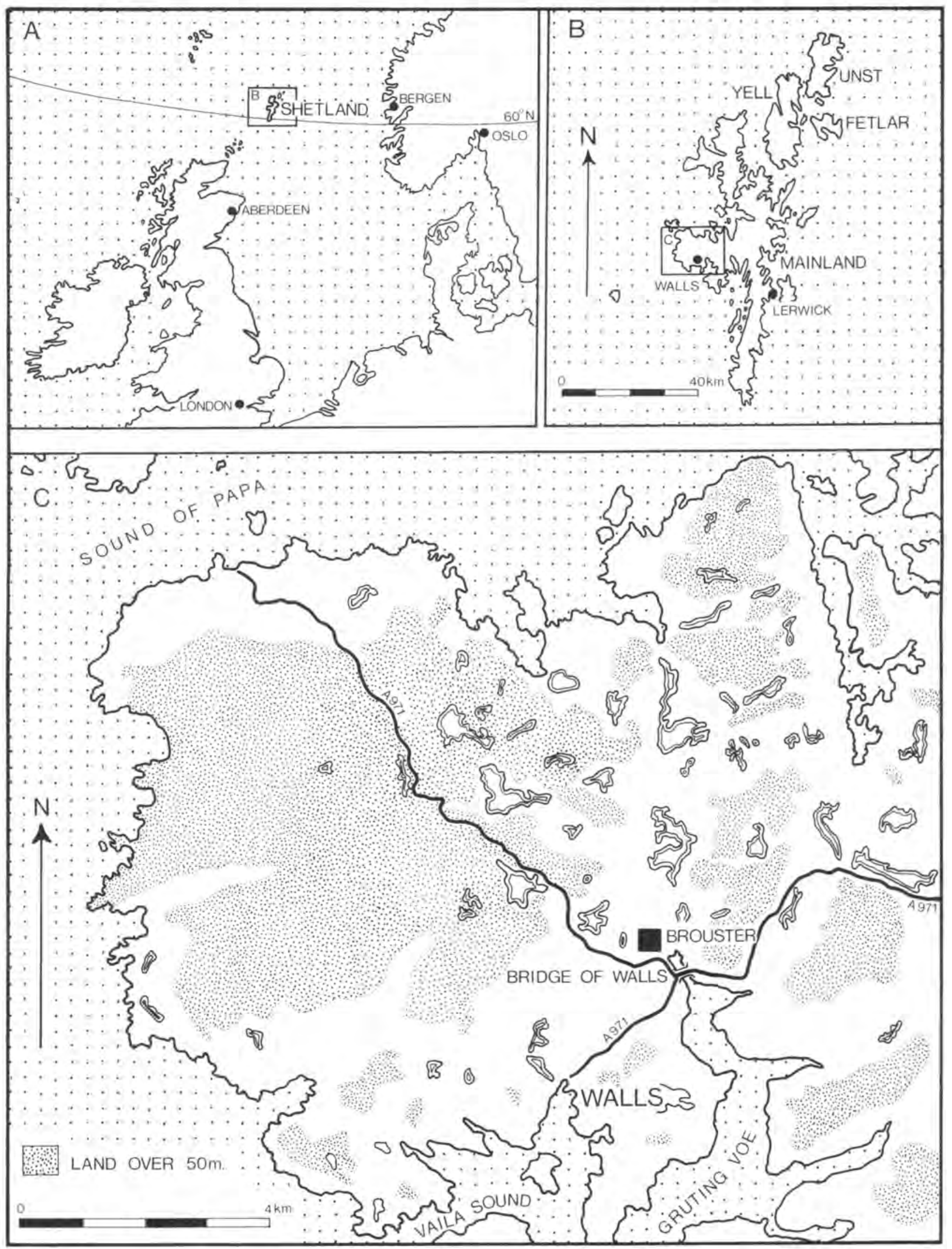

Illus 1 Location maps (Whittle 1986, fig 1) 


\section{Introduction}

The Scord of Brouster settlement and field system (HU 2560 5165) is situated in the west mainland, or Walls peninsula, of the Shetland Islands, at the northern shores of Gruting Voe (Illus 1). At the time of the Scord of Brouster excavation, the area of the Gruting Voe inlet had already been extensively investigated, and the site formed part of a group of mainly Neolithic and Bronze Age house sites and settlements (Calder 1956; Calder 1964). Scord of Brouster was excavated by Alasdair Whittle in the late $1970 \mathrm{~s}$, and the main purpose of the investigation was to shed light on early agricultural settlement in Britain by examining a settlement site in a remote part of the country, unspoilt by modern development. The fieldwork produced sizeable assemblages of pottery, stone tools and lithic artefacts (almost exclusively quartz), with struck, and probably struck, quartz numbering nearly 10,000 pieces. Unfortunately, the worked quartz was characterized at a time when quartz technology and, in particular, the associated bipolar technique was poorly understood, and, as the excavator puts it, ' . . . further advance in our understanding of this important raw material must be wished for as soon as possible' (Whittle 1986, 64).

To increase our understanding of quartz as a lithic resource, the project 'Quartz Technology in Scottish Prehistory' was initiated (Saville \& Ballin 2001). As part of this project, Scottish Mesolithic, Neolithic and Bronze Age quartz assemblages have been characterized, compared and discussed, with the lithic finds from Scord of Brouster forming part of the Neolithic reference material. The present analysis of the assemblage aims to:
- Characterize the lithic finds from Scord of Brouster according to modern standards, mainly by incorporating bipolar types of débitage and cores into the general type schema

- Discuss the spatial distribution of the lithic artefacts, within the individual buildings and across Houses $1-3$, as well as the activities associated with these artefacts

- Date the quartz assemblage, and its various sub-assemblages, by the recognition of diagnostic types and technological attributes; special attention is given to the presentation of the curved knives (Whittle 1986, 64-74), a tool type which may be chronologically and regionally diagnostic

- Compare the quartz assemblage from Scord of Brouster with contemporary lithic assemblages from other parts of Scotland, with the purpose of placing the site and assemblage in a regional context.

The lithic assemblage is characterized with special reference to raw materials, typological composition and applied technology.

The re-evaluation is founded upon a detailed catalogue of all the lithic artefacts from Scord of Brouster, and the artefacts in this paper are referenced by their number in this catalogue (CAT number); AW numbers refer to illustrations in Whittle's monograph on the Scord of Brouster (Whittle 1986). The catalogue is an archive document, copies of which are available on request from the National Monuments Record, Edinburgh. 


\section{The Assemblage}

In connection with the archaeological investigation of the site, 9687 lithic pieces were recovered. The composition of the assemblage is shown in Table 1.
The definitions of the main lithic categories are as follows:

Chips: All flakes and indeterminate pieces the

Table 1 Lithics - general artefact list (if the raw material of a type is not specified, all pieces are in quartz); two short end-scrapers in sandstone are described as part of the Scord of Brouster monograph's chapter on stone tools (Rees 1986, 84-5)

\begin{tabular}{|c|c|c|c|c|c|c|c|c|}
\hline & \multicolumn{4}{|c|}{ Numbers } & \multicolumn{4}{|c|}{ Percentages } \\
\hline & House 1 & House 2 & House 3 & Total & House 1 & House 2 & House 3 & Total \\
\hline \multicolumn{9}{|l|}{ Débitage and natural pieces } \\
\hline Chips, quartz & 854 & 755 & 8 & 1617 & 15.5 & 20.8 & 3.5 & 17.2 \\
\hline Flakes and indet. pieces, quartz & 4306 & 2748 & 170 & 7224 & 78.1 & 75.4 & 75.6 & 77.0 \\
\hline Flakes and indet. pieces, other & 8 & 8 & 1 & 17 & 0.2 & 0.2 & 0.4 & 0.2 \\
\hline Flakes and indet. pieces, flint & & 4 & & 4 & & 0.1 & & 0.1 \\
\hline $\begin{array}{l}\text { Flake with dorsal polish, } \\
\text { metamorphic rock }\end{array}$ & 1 & & & 1 & $<0.1$ & & & $<0.1$ \\
\hline Natural pieces, quartz & 308 & 120 & 44 & 472 & 5.6 & 3.3 & 19.6 & 5.0 \\
\hline Natural pieces, steatite or chlorite & 34 & 8 & 2 & 44 & 0.6 & 0.2 & 0.9 & 0.5 \\
\hline Total débitage & 5511 & 3643 & 225 & 9378 & 100.0 & 100.0 & 100.0 & 100.0 \\
\hline \multicolumn{9}{|l|}{ Cores } \\
\hline Single-platform cores & 13 & 6 & 1 & 20 & 23.2 & 15.4 & 100.0 & 20.8 \\
\hline $\begin{array}{l}\text { Cores with two platforms at an } \\
\text { angle }\end{array}$ & 6 & 1 & & 7 & 10.7 & 2.5 & & 7.3 \\
\hline Discoidal core & 1 & & & 1 & 1.8 & & & 1.0 \\
\hline Irregular cores & 5 & 6 & & 11 & 8.9 & 15.4 & & 11.5 \\
\hline Bipolar cores (incl one flint) & 28 & 23 & & 51 & 50.0 & 59.0 & & 53.1 \\
\hline Core fragments & 3 & 3 & & 6 & 5.4 & 7.7 & & 6.3 \\
\hline Total cores & 56 & 39 & 1 & 96 & 100.0 & 100.0 & 100.0 & 100.0 \\
\hline \multicolumn{9}{|l|}{ Tools } \\
\hline Leaf-shaped arrowheads & 2 & & & 2 & 1.7 & & & 0.9 \\
\hline Knife (scale-flaked) & 1 & & & 1 & 0.8 & & & 0.5 \\
\hline Curved (bifacial) knives & 5 & 7 & & 12 & 4.1 & 7.8 & & 5.7 \\
\hline Short end-scrapers (incl one felsite) & 62 & 54 & & 116 & 51.2 & 60.0 & & 54.7 \\
\hline Double-scrapers & 4 & 4 & & 8 & 3.3 & 4.4 & & 3.8 \\
\hline Side-scrapers (incl two flint) & 10 & 6 & & 16 & 8.3 & 6.8 & & 7.6 \\
\hline Side/end-scrapers & 5 & 1 & & 6 & 4.1 & 1.1 & & 2.8 \\
\hline Other scrapers & 4 & & & 4 & 3.3 & & & 1.9 \\
\hline Scraper-edge fragments & 6 & 4 & & 10 & 5.0 & 4.4 & & 4.7 \\
\hline Piercers & 4 & 2 & & 6 & 3.3 & 2.2 & & 2.8 \\
\hline Piece with oblique truncation & 1 & & & 1 & 0.8 & & & 0.5 \\
\hline Pieces with retouched notch(es) & 2 & & & 2 & 1.7 & & & 0.9 \\
\hline Denticulated pieces & & 2 & & 2 & & 2.2 & & 0.9 \\
\hline Pieces with invasive retouch & 3 & 4 & & 7 & 2.5 & 4.4 & & 3.3 \\
\hline $\begin{array}{l}\text { Pieces with edge-retouch (incl one } \\
\text { flint) }\end{array}$ & 9 & 5 & 1 & 15 & 7.4 & 5.6 & 100.0 & 7.1 \\
\hline Fabricator & 1 & & & 1 & 0.8 & & & 0.5 \\
\hline Hammerstones & 2 & 1 & & 3 & 1.7 & 1.1 & & 1.4 \\
\hline Total tools & 121 & 90 & 1 & 212 & 100.0 & 100.0 & 100.0 & 100.0 \\
\hline TOTAL & 5688 & 3772 & 227 & 9687 & & & & \\
\hline
\end{tabular}


greatest dimension (GD) of which is $\leq 10 \mathrm{~mm}$.

Flakes: All lithic artefacts with one identifiable ventral (positive/convex) surface, GD $>10 \mathrm{~mm}$ and $\mathrm{L}<2 \mathrm{~W}$ ( $\mathrm{L}=$ length; $\mathrm{W}=$ width).

Indeterminate pieces: Lithic artefacts which cannot be unequivocally identified as either flakes or cores. Generally, the problem of identification is due to irregular breaks, frost-shattering or fire-crazing. Chunks are larger indeterminate pieces, and in the case of quartz, for example, the problem of identification usually originates from a piece flaking along natural planes of weakness rather than flaking in the usual conchoidal way.

Blades and microblades: Flakes where $\mathrm{L} \geq 2 \mathrm{~W}$. In the case of blades $\mathrm{W}>8 \mathrm{~mm}$, in the case of microblades $\mathrm{W} \leq 8 \mathrm{~mm}$.

Cores: Artefacts with only dorsal (negative/concave) surfaces - if three or more flakes have been detached, the piece is a core; if fewer than three flakes have been detached, the piece is a split or flaked pebble.

Tools: Artefacts with secondary retouch (modification).

\subsection{Raw materials}

The lithic assemblage from Scord of Brouster consists almost entirely of quartz (9153 pieces of worked quartz), supplemented by eight pieces of flint, one piece of felsite, one piece of metamorphic rock and eight pieces of 'other' raw materials. Bagged with the worked lithics were 44 small pieces of raw steatite or chlorite and 472 gravel- and pebble-sized pieces of unworked quartz (some rounded, others - such as the pieces from House 3 - as more irregular, crumbly quartz/sandstone mixtures).

The struck quartz represents a number of varieties, such as white homogeneous milky quartz, a slightly bluish variety of milky quartz with a 'waxy' lustre, and fine-grained (saccharoidal) white quartz. Other varieties of quartz probably owe their different appearances (for example, colour and lustre) to anthropogenic factors, for example, exposure to fire. The author is presently carrying out experiments aimed at shedding light on the appearance of burnt quartz (Ballin, in prep d), with the burning of typically vitreous quartz resulting mainly in:

- a change of lustre from relatively clear and vitreous to dull and opaque

- 'pot-lidding' or pitting of the surface

- 'granulation' and, eventually, disintegration.

However, more research is required to expand our understanding of burnt quartz.

At Scord of Brouster, the above characteristics of burnt quartz are frequently associated with a yellow-brown colour, a phenomenon common to burnt quartz from later prehistoric (late Neolithic to Bronze Age) assemblages from the Western Isles, but not experienced in connection with the author's analyses of mainly Mesolithic assemblages from western mainland Scotland and Jura. Presently, the author's working hypothesis is that this discolouration may be associated with the burning of peat, and experiments to test this theory are in progress. The number of burnt quartz pieces cannot be quantified accurately at present, but for the Scord of Brouster assemblage burnt quartz is estimated at $c$ $41 \%$ of the total.

This is a fairly high proportion, but in Scotland large quantities of burnt quartz characterize many late prehistoric assemblages, such as those from Rosinish, on Benbecula, and Calanais and Dalmore, on Lewis (Ballin, forthcoming b; Ballin, in prep a; Ballin, in prep c). In these three cases, burnt quartz makes up between one-third and half of the assemblage. The cause of these high burnt quartz ratios is presently unknown.

The physical attributes of the quartz from Scord of Brouster suggest the exploitation of a number of different raw material sources. The presence of smooth abraded surfaces is evidence of the collection of pebble quartz from a beach source, whereas rough surfaces and the frequent adhesion of material from the original rock matrix indicate the quarrying of vein quartz (cf Ballin 2004). Vein quartz commonly forms layers separated by cracks, and along these cracks the adjoining surfaces tend to acquire colours such as red, yellow or brown. A small number of pieces exhibit these surfaces, supporting the suggested use of vein quartz.

The rock adhering to the quartz includes several different types, such as sandstone, feldspar and steatite or chlorite, demonstrating the exploitation of more than one vein. Samples of the latter were discussed with geologist Dr Alan Hall (Department of Archaeology, University of Glasgow), with the author believing the adhering material to be steatite (due to the on-site presence of fragmented steatite vessels, demonstrating the procurement of this material), but according to Dr Hall it is almost impossible, when dealing with geological handsamples, to distinguish between steatite and chlorite. The sandstone indicates the use of local veins, as the area around Gruting Voe is completely dominated by Old Red Sandstone (Mykura 1976, 52). The large feldspar crystals points to the use of veins from areas of igneous (granite) or metamorphic rock (gneiss), whereas steatite and chlorite indicate the exploitation of veins from areas of metamorphic rock. The nearest known outcrops of granite or gneiss are at $6-10 \mathrm{~km}$ distance towards the south (the Sandsting Complex) and east (east of the Walls Boundary Fault) (Mykura 1976, figs 9-10), whereas the steatite/chlorite may derive from the metamorphic zone east of the Walls Boundary Fault (Mykura 1976, plate IV).

Eight flint pieces (four flakes, one core and three tools) are in light-brown, fine-grained flint with few impurities and good flaking properties. Only one piece is corticated (CAT 595), with the cortex being smooth and abraded. The cortex of CAT 595 suggests 
the exploitation of a pebble source, with the only known Shetland source being beach deposits on Yell (Whittle 1986, 72).

One small end-scraper (CAT 2293) is in a grey, mottled rock type with one face being polished. The piece was examined by Dr Hall, who defined it as a feldspathic porphyry, or felsite. The main outcrops of felsite are in the northern parts of mainland Shetland, on the peninsula of North Roe (Mykura 1976, 94-5). During the late Neolithic and Early Bronze Age (Fojut 1986, 17-18; Saville 1994, 60-1) this material was used in the manufacture of large unperforated axeheads and polished 'Shetland knives'. With a thickness of more than $1 \mathrm{~cm}$, it is most likely that the scraper in question was formed on a piece of an abandoned axehead, and not a fragment of a thin polished knife. Usually, felsite displays a range of very bright blue to bluish-green colours, and the dull appearance of CAT 2293 is probably due to its having been burnt.

A distal fragment of a flake with a polished dorsal facet (CAT 2294) is most probably a part of an abandoned axehead. The piece was also examined by Dr Hall, who classified it as a green meta-sedimentary (metamorphic) rock. The provenance of this rock type is presently unknown, but metamorphic rocks are not present in the immediate vicinity of the site.

Seventeen flakes and indeterminate pieces have been defined as 'other' rock types. Most of these are probably varieties of sandstone from the local Walls Formation (Mykura 1976, 61), the same type of sandstone as the one adhering to many of the worked and unworked pieces of quartz. Though this material is coarse-grained and breaks up easily it was used in the manufacture of tools; two scrapers from Scord of Brouster are in sandstone (presented as part of the assemblage of stone implements; Rees 1986, 84-5), and a number of large scrapers in the present collection are in a layered mixture of quartz and sandstone (CAT 2038, 2065, 2234). When used to process hard materials (wood, bone, antler), quartz scrapers are rendered useless after a few hundred strokes (Broadbent \& Knutsson 1975), and one must assume that the 'lifetime' of a scraper with a sandstone edge would be considerably shorter than that of a pure quartz scraper.

\subsection{Débitage}

Due to the fact that a large proportion of the débitage has been burnt to a degree preventing precise characterization, as well as constraints on time, it was decided to combine the two categories of flakes and indeterminate pieces. A total of 8863 pieces of débitage were recovered: 1617 chips and 7246 flakes and indeterminate pieces; true blades are practically absent. All the chips are in quartz, whereas 7224 flakes and indeterminate pieces are in quartz, with four being in flint and 17 in 'other' raw materials (mainly sandstone). One flake with dorsal polish is in a green metamorphic rock (CAT 2294).
Table 2 The percussion techniques applied to detach the tool blanks

\begin{tabular}{lcc}
\hline & Numbers & Percentages \\
\hline Bipolar technique & 33 & 24 \\
Hard percussion & 25 & 18 \\
$\begin{array}{l}\text { Indeterminate } \\
\text { platform }\end{array}$ & 7 & 5 \\
technique & & \\
Uncertain & 73 & 53 \\
TOTAL & 138 & 100 \\
\hline
\end{tabular}

The chip ratio (17.2\%) was not very high, indicating either limited primary production on the site (Ballin \& Lass Jensen 1995, 227) or lack of consistent sieving (selective sieving?) during retrieval (Illus 2). The high proportion of débitage $(c 97 \%)$ in relation to tools (c 2\%), combined with the retrieval of many cores (96 pieces) and three hammerstones, suggest the latter.

Due to the severely burnt state of a large proportion of the assemblage it was decided not to undertake an attribute analysis of the sizeable collection of débitage. However, the initial general classification process did give the author an impression of the applied percussion techniques, and the débitage was undoubtedly dominated by bipolar material, though flakes detached by the application of hard percussion were also common. A significant proportion of the platform flakes had trimmed platform-edges.

The general characterization of the tools (see below) includes definition of the applied percussion techniques (Table 2) and, though the technological attributes of the tool blanks may not necessarily mirror those of the débitage exactly, the tool blanks support the general impression presented above.

\subsection{Cores}

In total, 96 cores were retrieved during the excavations: 20 single-platform cores, seven cores with two platforms at an angle, one discoidal core, 11 irregular cores, 51 bipolar cores and six indeterminate core fragments. The percentage distribution of platform cores:bipolar cores is 47:53. Apart from one bipolar core in flint, all cores are in quartz.

The dimensions $(\mathrm{L} \times \mathrm{W} \times \mathrm{Th})$ of cores are measured in the following ways: in the case of platform cores, the length is measured from platform to apex, the width is measured perpendicular to the length with the flaking-front orientated towards the analyst and the thickness is measured from flaking-front to the often unworked/cortex-covered 'back-side' of the core. In the case of bipolar cores, the length is measured from terminal to terminal, the width is measured perpendicular to the length with one of the two flaking-fronts orientated towards the analyst 


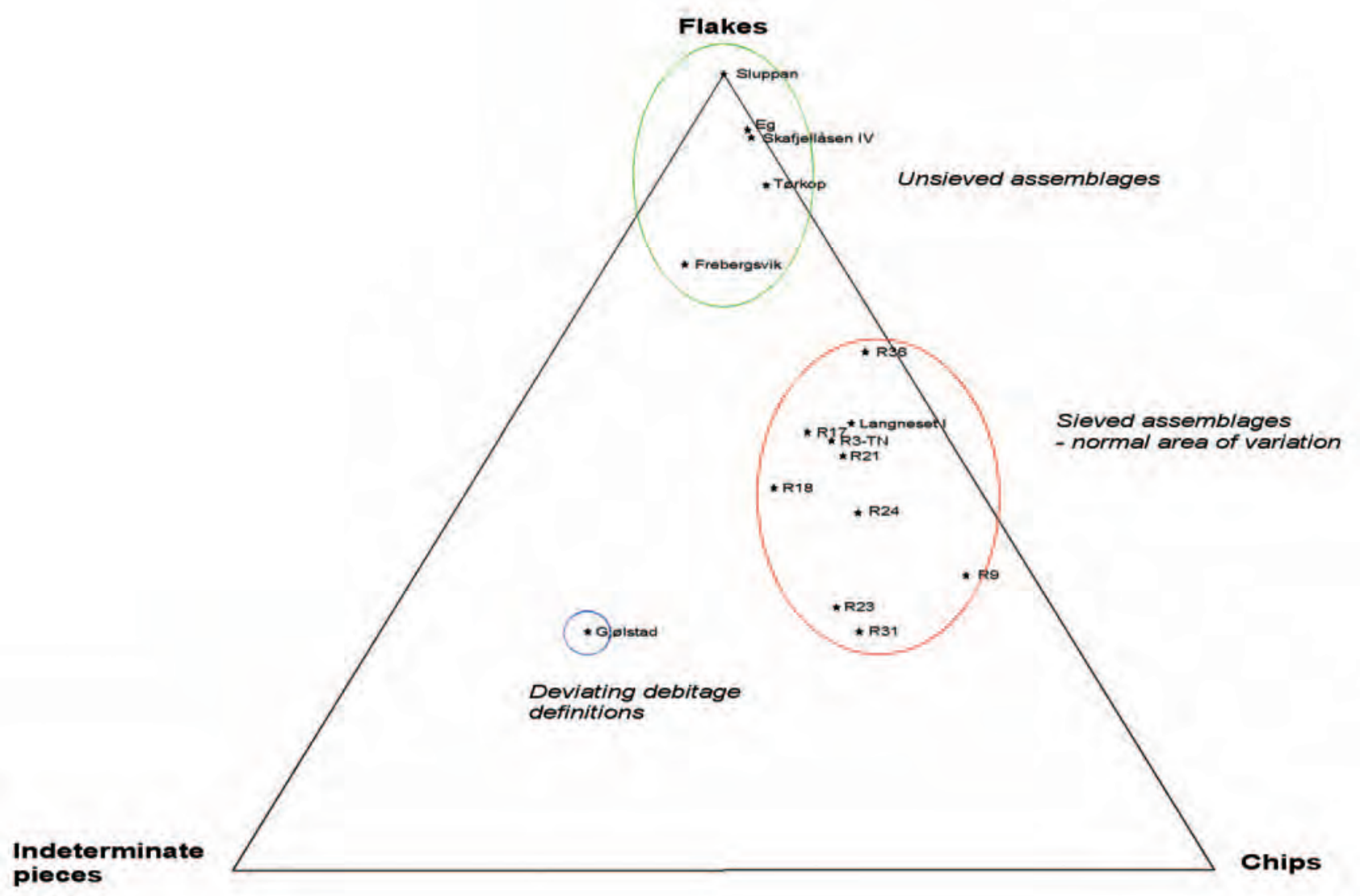

Illus 2 The distribution of débitage on chips, flakes and indeterminate pieces in sieved and unsieved Norwegian assemblages (Ballin 1999b, 103). In unsieved assemblages the chip ratio varies between $c 0$ and $10 \%$, and in sieved assemblages between c 30 and $55 \%$

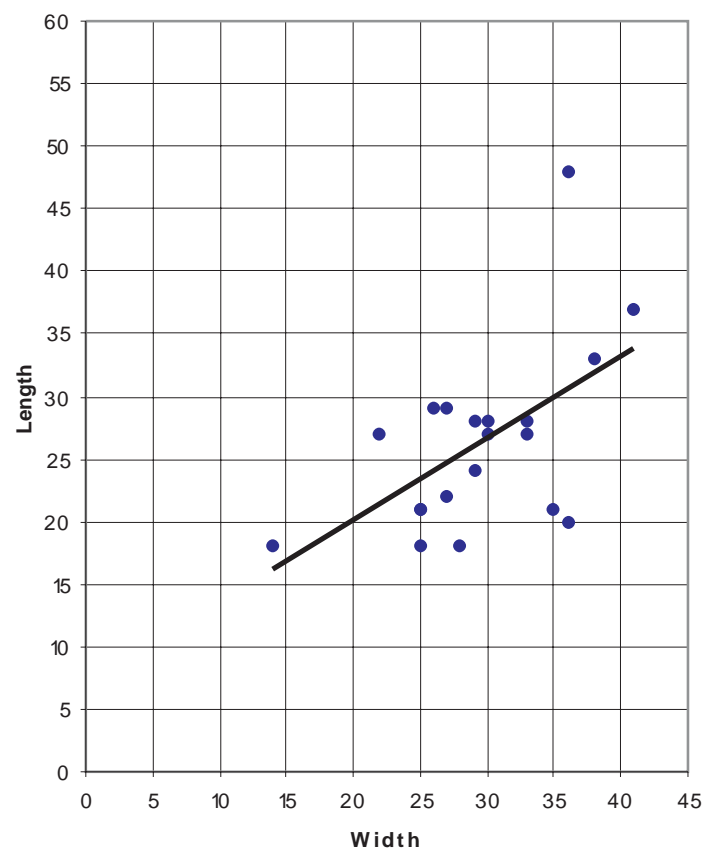

Illus 3 The dimensions of all single-platform cores (incl fragmented specimens) and the thickness is measured from flaking-front to flaking-front.

Twenty single-platform cores are recovered from the site, 13 of which are fragmented. The seven intact cores are all relatively small (average dimensions: $27 \times 29 \times 34 \mathrm{~mm}$; Illus 3 ), with some of the fragmented cores being considerably smaller (for example, CAT 2085). The shapes of the cores differ considerably, with some being regular and approximately conical or sub-conical (for example, CAT 2059, 2085, 2095) (Illus 4; Illus 5; AW 59.34, 59.38, $60.1,60.8,61.35,61.44$ ), whereas two (CAT 2227, 2290) (Illus 7; Illus 8; AW 60.3,60.6) were formed as handle-cores or keeled cores, with the main flaking-front being at one narrow end of an elongated platform. However, due to the irregular flaking patterns of quartz, most of the singleplatform cores are less than regular, and their platforms tend to be slightly angular (for example, CAT 2072) (Illus 6).

Two cores are knapped around the entire circumference (CAT 2059, 2275), while 10 are knapped around three-quarters to half of the circumference, and two only around one-quarter of the circumference. Six fragmented cores are knapped around the entire surviving part of the circumference. Approxi- 


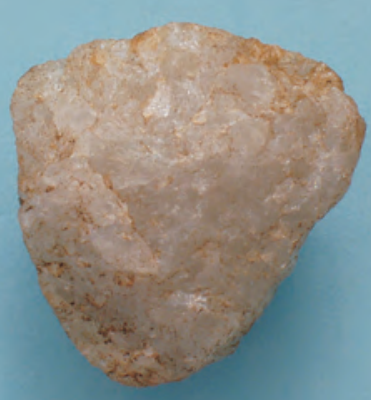

$\begin{array}{llllll}\mathrm{CM} & 1 & 2 & 3 & 4 & 5 \\ & & & & & \end{array}$

Illus 4 Single-platform core: CAT 2059

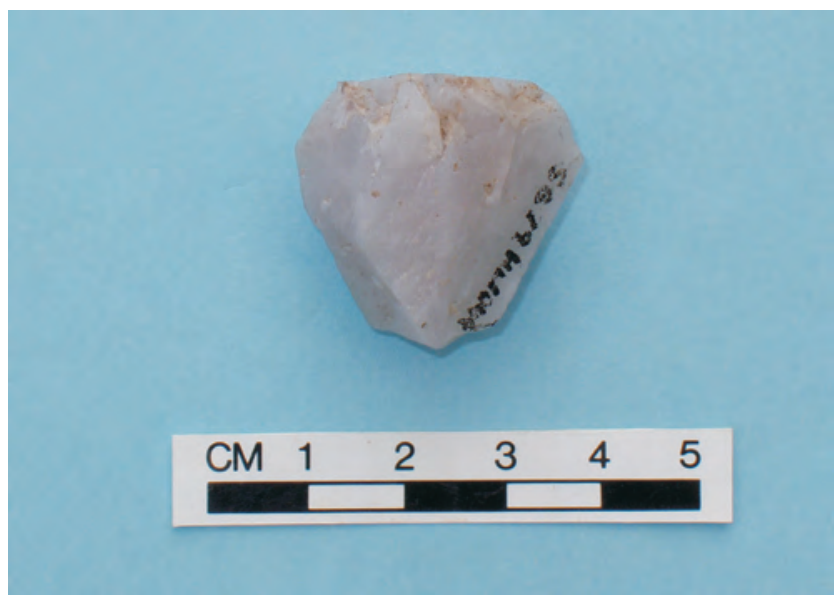

Illus 6 Single-platform core: CAT 2072

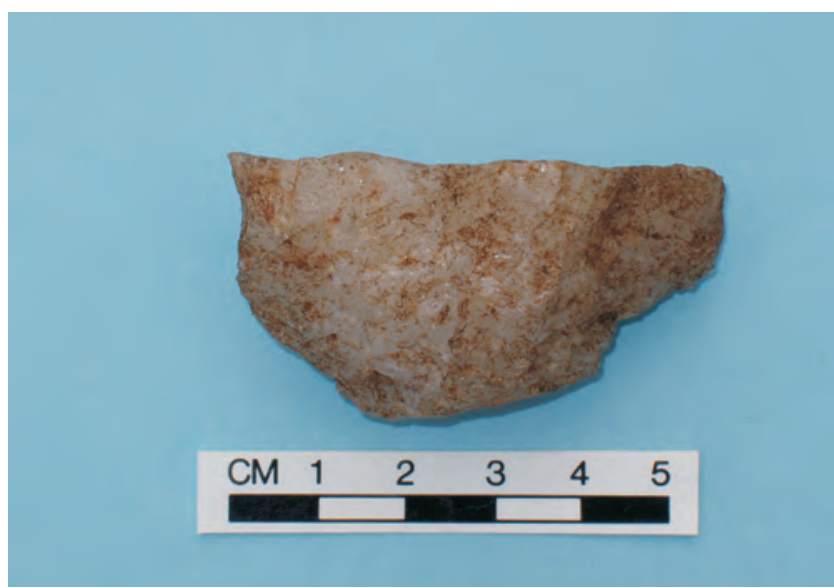

Illus 8 Handle-core: CAT 2290

mately half (11 pieces) of the platform-edges are regularly trimmed. Most of the platforms are plain, and only in a few cases (for example, CAT 2085) was faceting of the platform carried out as part of the core preparation. In two cases (CAT 2039, 2059), part of a bilateral crest survives at the apex.

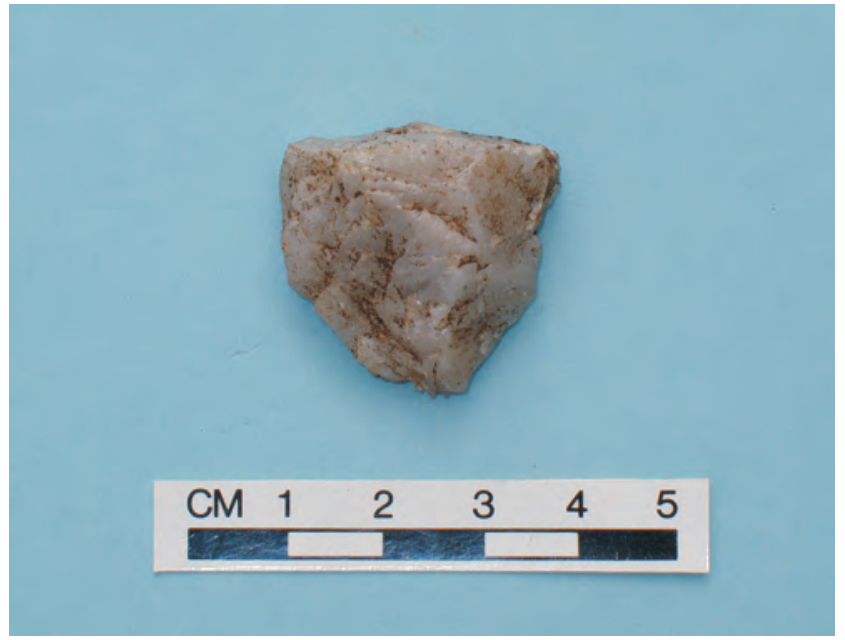

Illus 5 Single-platform core: CAT 2095

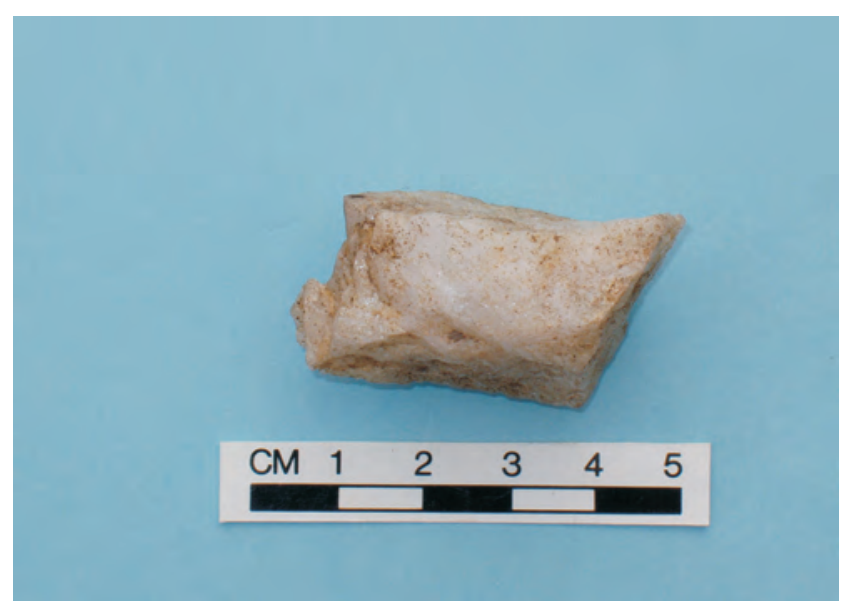

Illus 7 Handle-core: CAT 2227

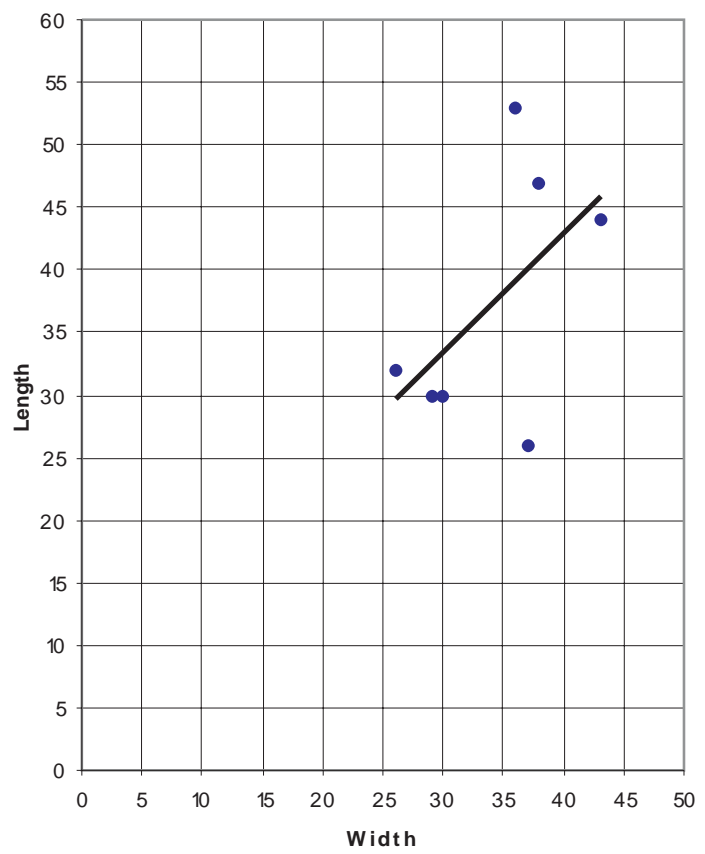

Illus 9 The dimensions of all cores with two platforms at an angle 


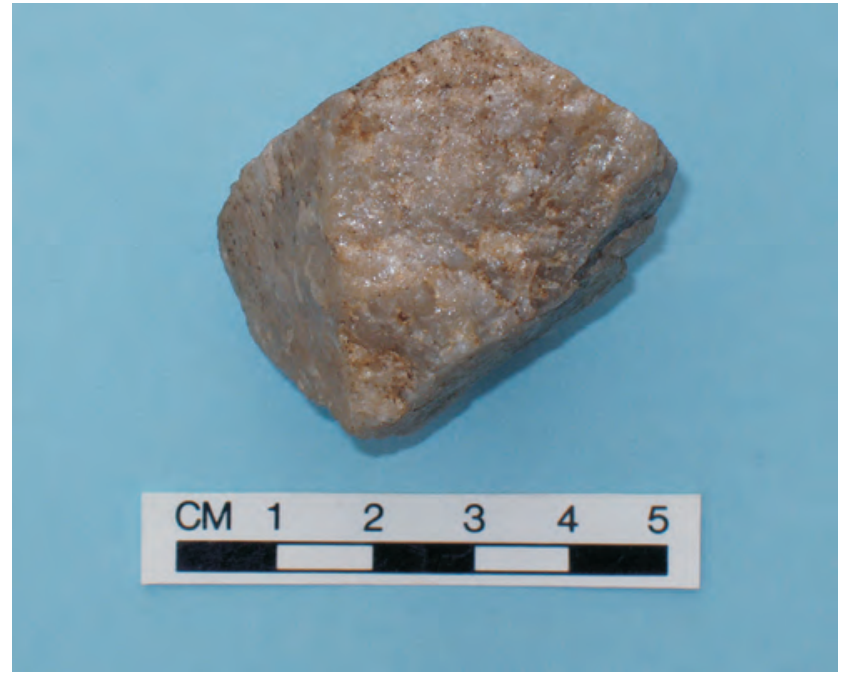

Illus 10 Core with two platforms at an angle: CAT 2217

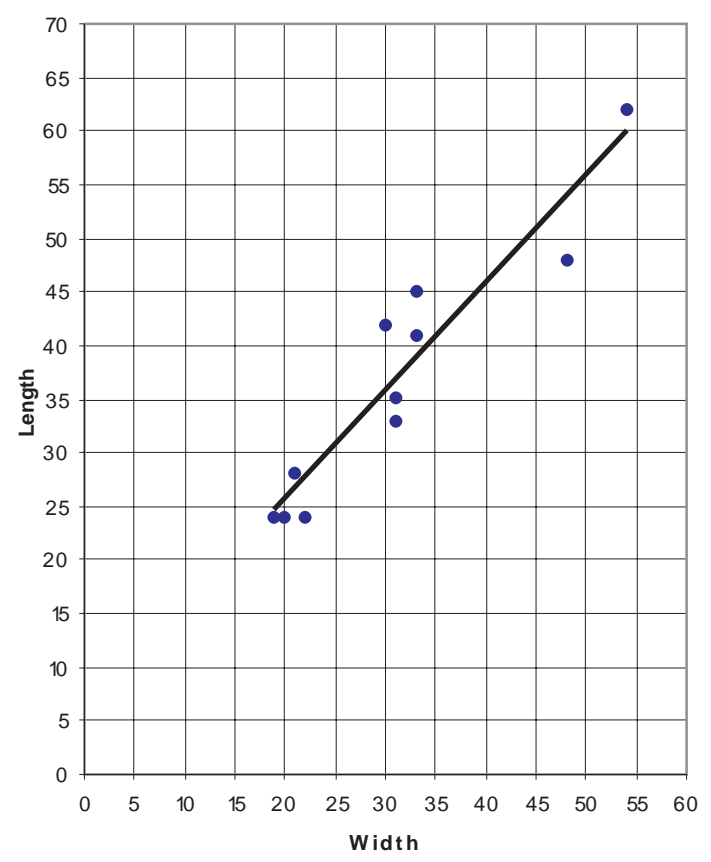

Illus 12 The dimensions of all irregular cores

The seven cores with two platforms at an angle are generally larger than the single-platform cores (av dim: $37 \times 34 \times 26 \mathrm{~mm}$; Illus 9 ), and less regular (Illus 10 ; Illus 11; AW 58.20, 60.5, 61.46). Most of the cores (CAT 2055, 2117, 2206, 2226, 2292) have one platform approximately at a right angle to the other platform, and probably represent continued reduction of single-platform cores; these pieces are relatively regular. Two cores (CAT 2056, 2217) have one platform at a distinctly oblique angle to the other platform and are morphologically more akin to irregular cores, though they probably represent continued reduction of single-platform cores. Most of these dual-platform cores are roughly cubic, and their platform-edges are generally untrimmed.

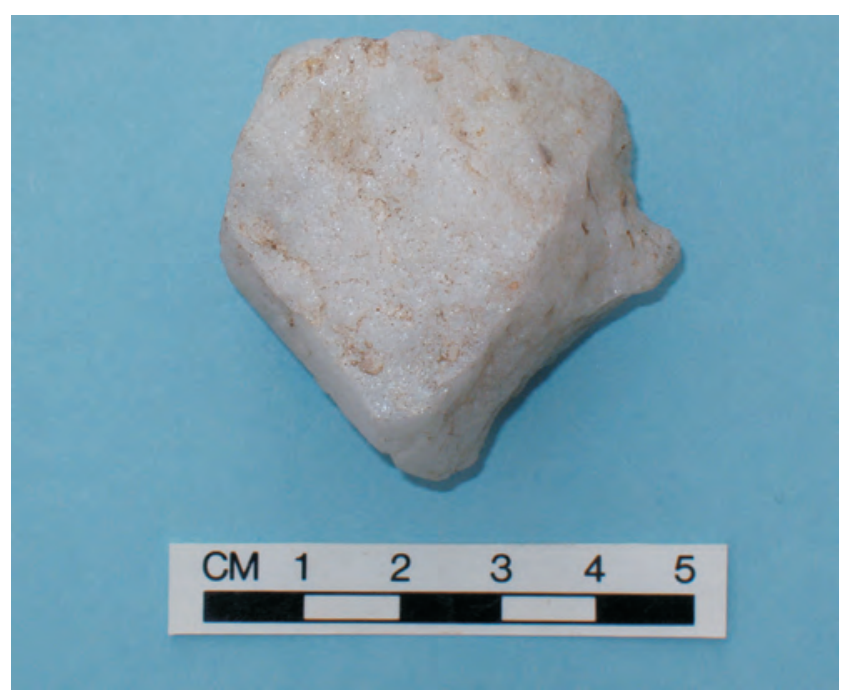

Illus 11 Core with two platforms at an angle: CAT 2292

With 11 specimens, irregular cores are fairly common (AW 58.17). They vary considerably in size (av dim: $37 \times 31 \times 24 \mathrm{~mm}$; GD 24-65mm; Illus 12), with four being very small (CAT 2158, 2181, 2218, 2231), five medium-sized (CAT 2069, 2096, 2169, 2241 ) and two very large (CAT 2070, 2255). They are mostly amorphous, though a small number possess one or more regular platform-edges (for example, CAT 2070, 2096).

One fragmented discoidal core (for definition, see Wickham-Jones 1990, 58) was recovered from Scord of Brouster $(38 \times 22 \times 21 \mathrm{~mm})$. One side of this disc-shaped piece has broken off, leaving approximately three-quarters of the original, circular knapping seam. Along the edges of the break a number of little flakes have been detached. The assemblage also includes six core fragments (core fragments are defined as fragments of cores which cannot be identified more precisely; Ballin 1996, 13 - if a fragment of a core can be defined as the fragment of a specific core type, the piece is listed with these cores), mostly smaller than GD $25 \mathrm{~mm}$ (av dim: $26 \times 26 \times 18 \mathrm{~mm}$ ). In all cases, a stretch of platform-edge survives, defining them as fragments of platform cores, but they cannot be classified more precisely. Half of the platform-edges are trimmed and half of them are untrimmed.

More than half of the cores (51 specimens) are bipolar cores (Illus 13; Illus 14; AW 58.1, 58.22, $59.32,60.4,60.7,60.18,60.33,61.58)$. They form a relatively homogeneous group of small cores (av dim: $27 \times 20 \times 12 \mathrm{~mm})$ and, unlike other quartz assemblages (for example, Lussa River and Bayanne; Ballin 2002; Ballin, forthcoming c), no large bipolar cores suggest the use of bipolar technique for quartering nodules, or as an exclusive approach for reducing nodules. Most likely the majority of the bipolar cores from Scord of Brouster represent the final reduction of exhausted platform cores, as illustrated by a small number of cores (for example, CAT 2256) with surviving stretches of platform-edge on 


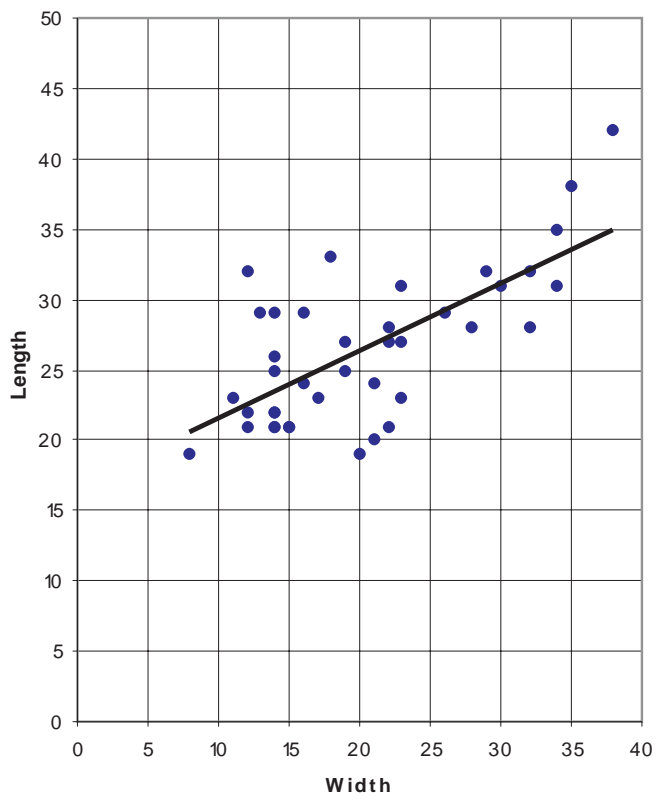

Illus 13 The dimensions of all intact bipolar cores one face. CAT 2073 is a bipolar core on a large milky-quartz crystal - one face display five crystal facets, and the original crystal probably had a diameter of $c 30 \mathrm{~mm}$. Approximately $78 \%$ of all bipolar cores have one set of terminals, with the remainder having two sets of terminals. This evidence indicates that approximately one-fifth of the bipolar cores were re-orientated during the reduction process.

\subsection{Tools}

The 212 tools are heavily dominated by 160 scrapers (75\%), compared to 52 other tools. The 'other' tools include two leaf-shaped points, one scale-flaked knife, 12 curved bifacial knives, six piercers, one truncated piece, two notched pieces, two denticulated pieces, seven pieces with invasive retouch, 15 pieces with edge-retouch, one fabricator and three hammerstones. The tool ratio is $2.3 \%$, which is similar to, or slightly higher than, the ratio

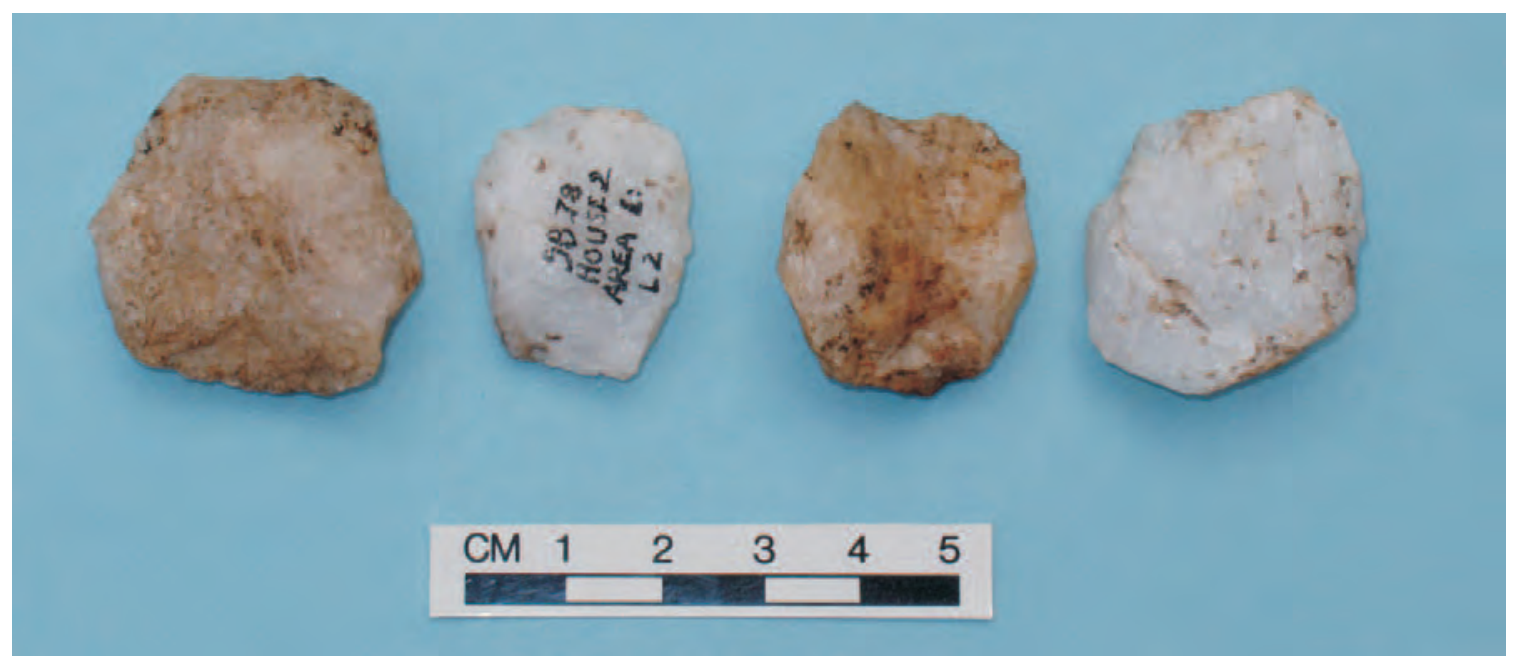

Illus 14 Bipolar cores: CAT 2022, 2015, 2014, 2108

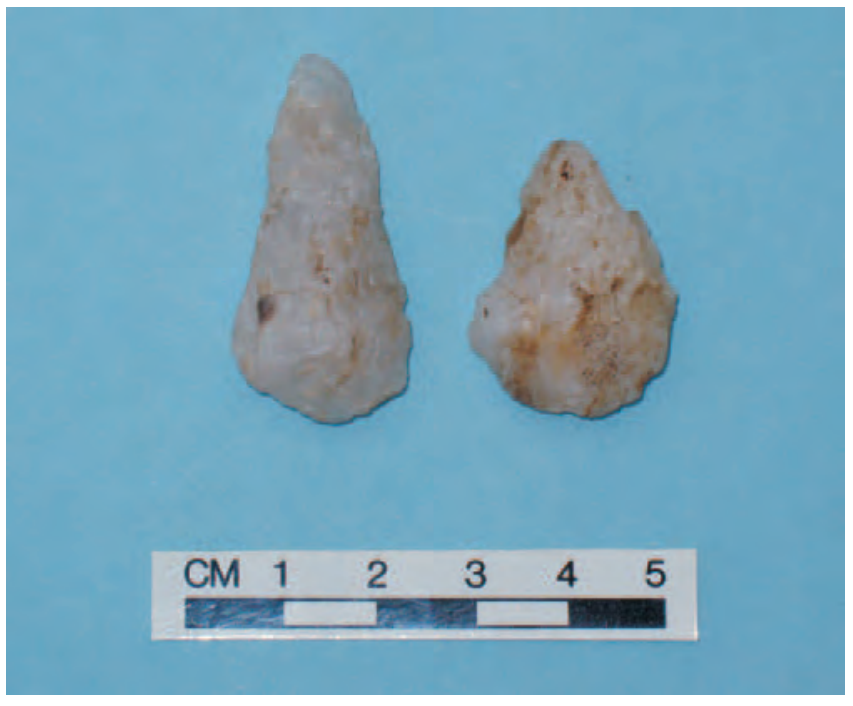

Illus 15 Leaf-shaped points: CAT 2296, 2297 of many quartz assemblages (usually 1-1.5\%). It is highly likely that some tools have been missed, as retouch, and particularly delicate retouch, may be difficult to recognize on the white, reflective surfaces of quartz. In the present case, some retouched areas may have been shed, along with the general 'peeling-off' of surfaces as a result of the artefacts' exposure to fire (see Section 3.1 - Raw materials, above). Apart from two side-scrapers (CAT 2209, 2269) and one edge-retouched piece (CAT 2267) in flint, all tools are in quartz.

\subsubsection{Arrowheads}

Two leaf-shaped arrowheads were found during the excavations (Illus 15; AW 60.28-29). One (CAT 2297) is teardrop-shaped, short and squat $(28 \times 21 \times 7 \mathrm{~mm})$ 


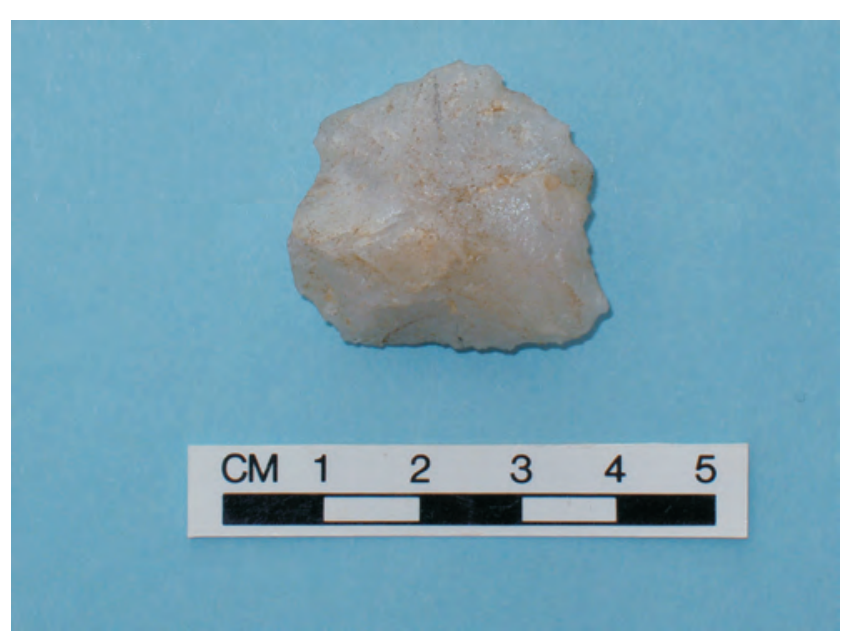

Illus 16 Scale-flaked knife: CAT 2243

with uneven, crudely denticulated lateral edges; it may be a rough-out. The other (CAT 2296) is elongated and slim $(38 \times 19 \times 9 \mathrm{~mm})$ with the broadest point near the base; as the straight lateral sides meet the pointed base at obtuse angles, the point assumes an approximate kite-shape. The two pieces belong to Green's types 3A and 3C, respectively (Green 1980, 69-72).

\subsubsection{Scale-flaked knife}

CAT 2243 (Illus 16; AW 60.21) has been classified as a scale-flaked knife (definition following Healy 1996, 76). One straight lateral side has been sharpened by acute, slightly denticulated, scale-flaked retouch, whereas the other side is angularly curved with sporadic blunting of the central part. The knife is on a thick hard-hammer flake $(29 \times 28 \times 13 \mathrm{~mm})$.

\subsubsection{Curved knives}

The term 'curved knives' was suggested by Whittle in the original presentation of the finds from Scord of Brouster (Whittle 1986, 66-72) and, considering the general morphology of the pieces (see presentation below), the term must be considered apt. According to Whittle, this tool type has not been found anywhere else in the Northern Isles, and he suggests that the type may have been missed from earlier excavations on Shetland (Whittle 1986, 72). By examining the wider archaeological record, the author has only been able to find two other British curved knives, namely a piece from Camster Long, Caithness (no 28 in Davidson \& Henshall 1991, illus 21; no 367 in Wickham-Jones 1997, fig 22), and a piece from Druim Arstail, Oronsay (Wickham-Jones et al. 1982, plate 3.197). The flint implement from Camster Long is bifacial and asymmetrical, with one lateral side being distinctly concave (the cuttingedge) and the other distinctly convex. The marked

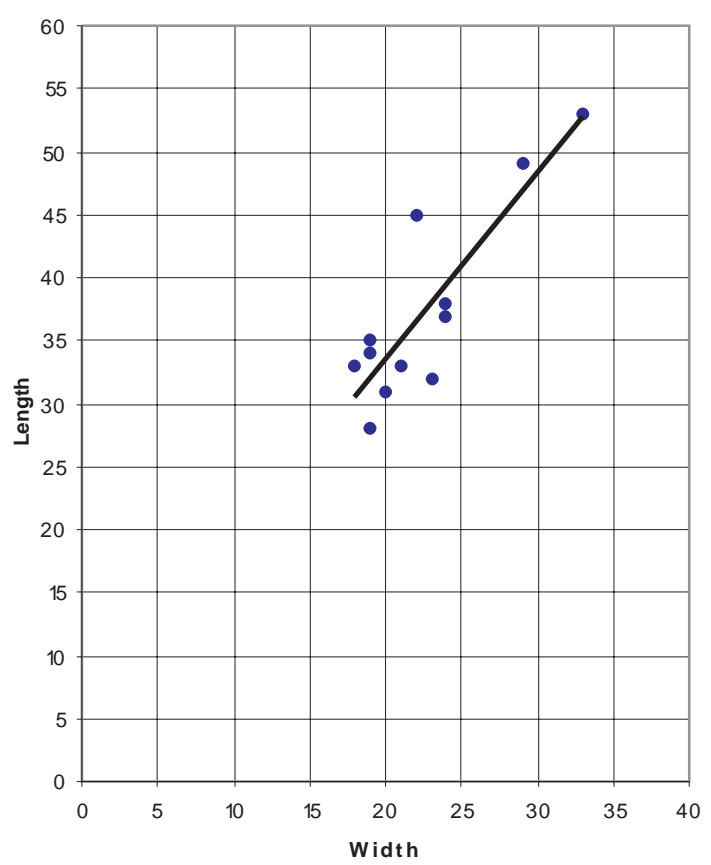

Illus 17 The dimensions of all curved knives

lack of symmetry rules out the possibility that it may be a variant of the leaf-shaped arrowhead or a rough-out for an arrowhead. Like the present assemblage, the Camster Long material includes kiteshaped arrowheads. The piece from Druim Arstail has the same shape as the Scord of Brouster curved knives of type 3 (see below), and the assemblage includes a number of different leaf-shaped points as well as barbed-and-tanged arrowheads and a possible chisel-shaped point.

Twelve bifacially retouched artefacts have been classified as curved knives on the basis of their general curved shape. With the exception of two larger pieces (CAT 2305, 2306), the knives are of roughly the same size (av dim: $37 \times 23 \times 9 \mathrm{~mm}$; GD 28$53 \mathrm{~mm}$; Illus 17 ). They are mainly characterized by one lateral side being convex and one concave, with varying shapes of base and tip. The pieces either have a flat base, which in most cases represents the blank's platform remnant (CAT 2301, 2304, 2305, 2306), or a bifacially shaped ridge (a 'knapping seam') connecting the two lateral sides (CAT 2298, 2299, 2300,?2302); CAT 2309 seems to be a hybrid form, and CAT 2303 has had the base shaped by edge-retouch of a (pre- or post-modification?) break. Some bases are straight, and some are more or less convex, but CAT 2298 has a rudimentary basal tang. The tips are either pointed (CAT 2298, 2299, 2302, 2303, 2305, 2306,2309 ) or rounded (CAT 2300, 2301, 2304). The curvature of either lateral side is more or less pronounced. CAT 2302 has a small patch of steatite/ chlorite on one face, and two pieces (CAT 2300, 2307) retain small areas of abraded cortex.

Based on a number of morphological attributes, the curved knives may be sub-divided into four groups (Table 3): 


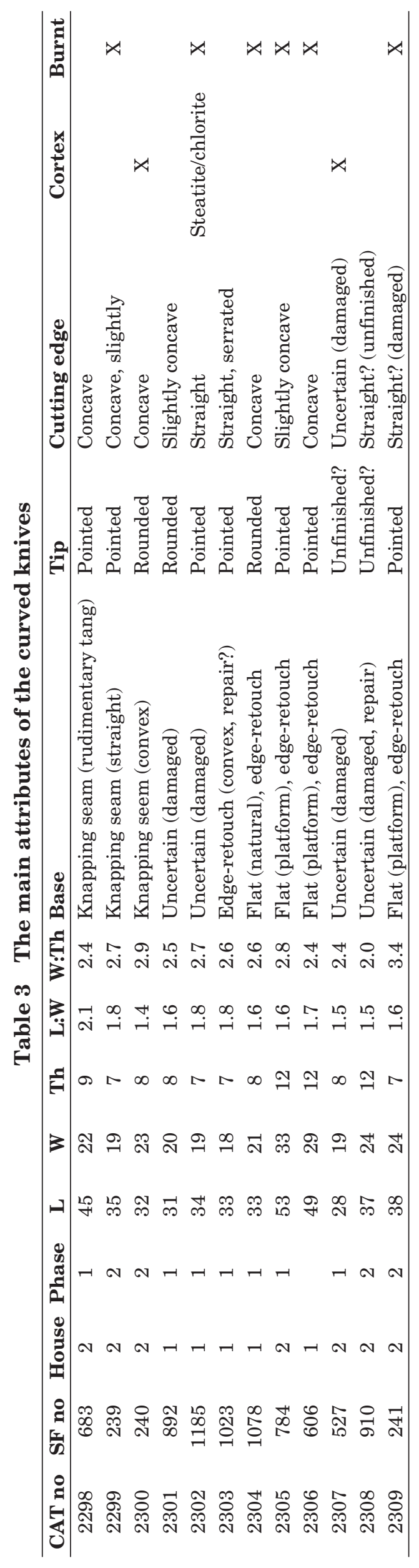




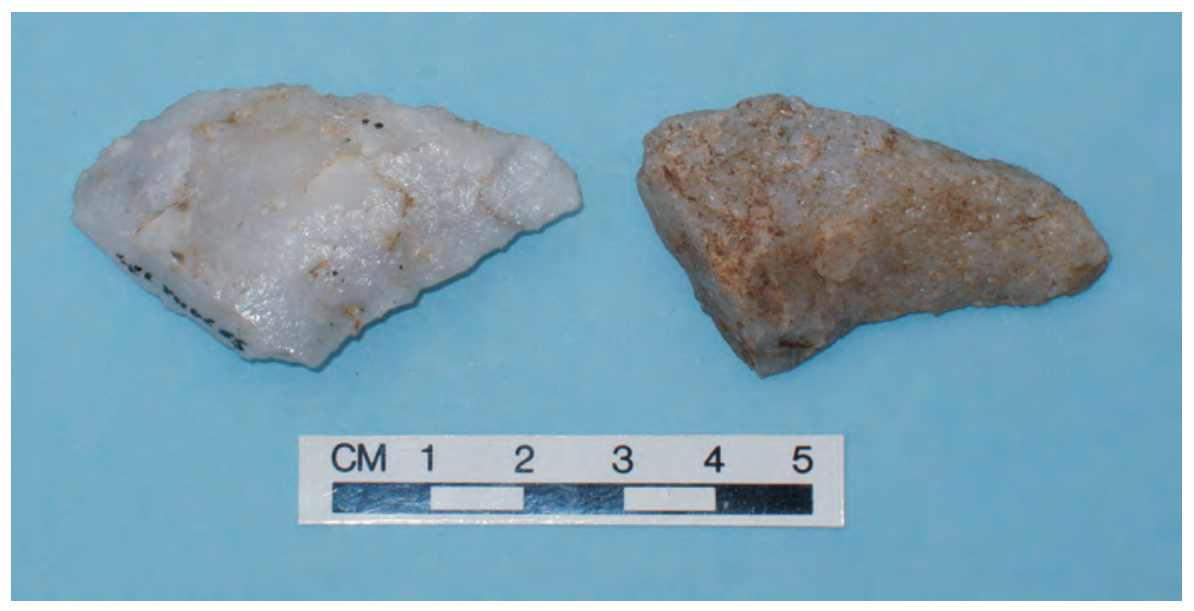

Illus 18 Curved knives, category 2: CAT 2305, 2306

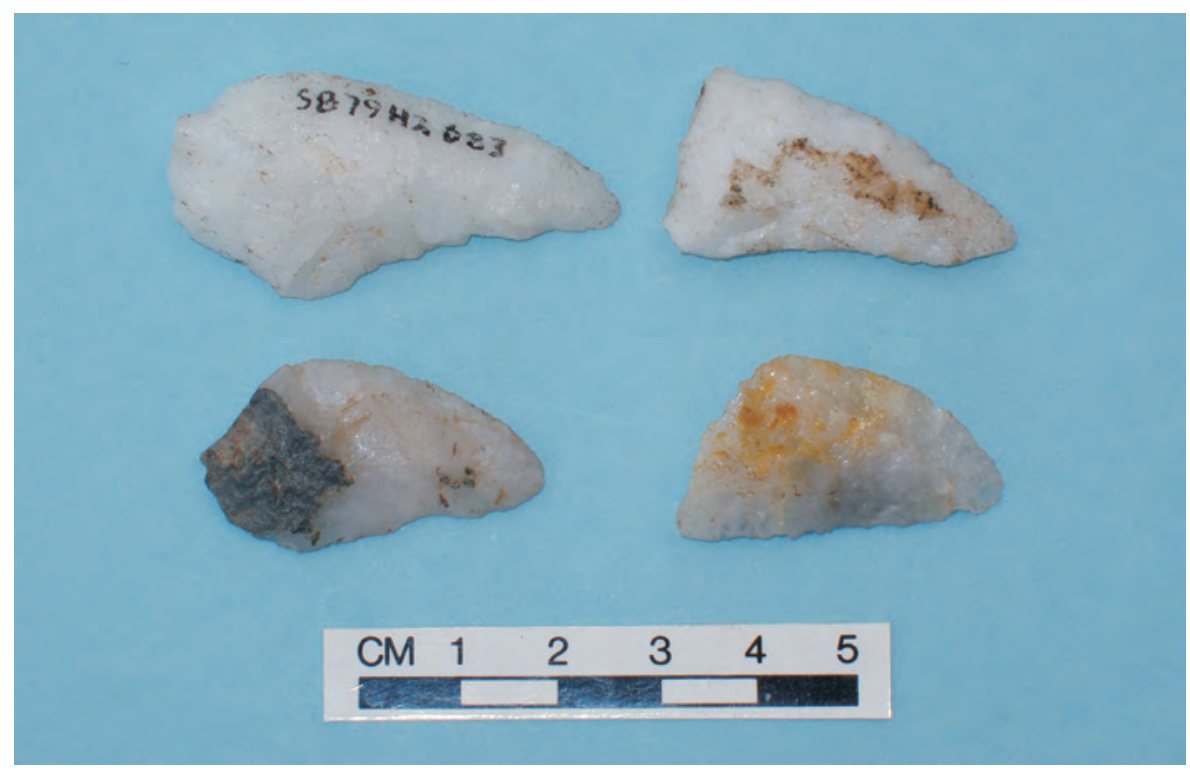

Illus 19 Curved knives, category 3: CAT 2298, 2299, 2302, 2303

Type 1 Two specimens (CAT 2307, 2308) are relatively crude, thick pieces and may be rough-outs (av dim: $33 \times 22 \times 10 \mathrm{~mm}$ ); neither lateral sides, faces, bases nor tips have been finished off, and the curvature of the concave cutting edge is less pronounced - CAT 2307 may be fragmented (AW $58.12,58.15)$.

Type 2 Two pieces (CAT 2305, 2306) are larger than average (av dim: $51 \times 31 \times 12 \mathrm{~mm}$ ), with pointed tips and flat bases (Illus 18; AW 58.11).

Type 3 Five curved knives (CAT 2298, 2299, 2302, 2303, 2309) form the largest sub-group, being of approximately the same small size with pointed tips (av dim: $37 \times 20 \times 7 \mathrm{~mm}$ ) - most have ridged bases (Illus 19; AW 58.10, 59.26, 59.28, 60.23-4).

Type 4 Three small and slightly shorter pieces (CAT $2300,2301,2304$ ) (av dim: $32 \times 22 \times 8 \mathrm{~mm}$ ) have rounded tips and either flat or ridged bases (Illus 20; AW 59.27, 60.22, 60.25). Curved knives of Type 4, with rounded tips, may be repaired specimens of Type 3 knives, which have had their pointed tips broken off.

Two knives (CAT 2306, 2309) are severely burnt and three (CAT 2302, 2304, 2305) are slightly burnt, obscuring the finer details somewhat, but CAT 2298, $2299,2300,2301$ and 2303 are fine pieces with delicate bifacial retouch. The central, unmodified part of each face of CAT 2299 appears burnt, whereas the peripheral areas have been shaped by the application of invasive retouch; though some analysts dispute the usefulness of heat-treating quartz (Flennikin 1981, 27; this statement is modified by Knight 1991, 44, who proposes that heat treatment of quartz may not alter the quartz itself, but the heat possibly alters minerals within the quartz, thereby improving the working characteristics of the quartz), this particular piece may nevertheless have been subjected to this specialized 


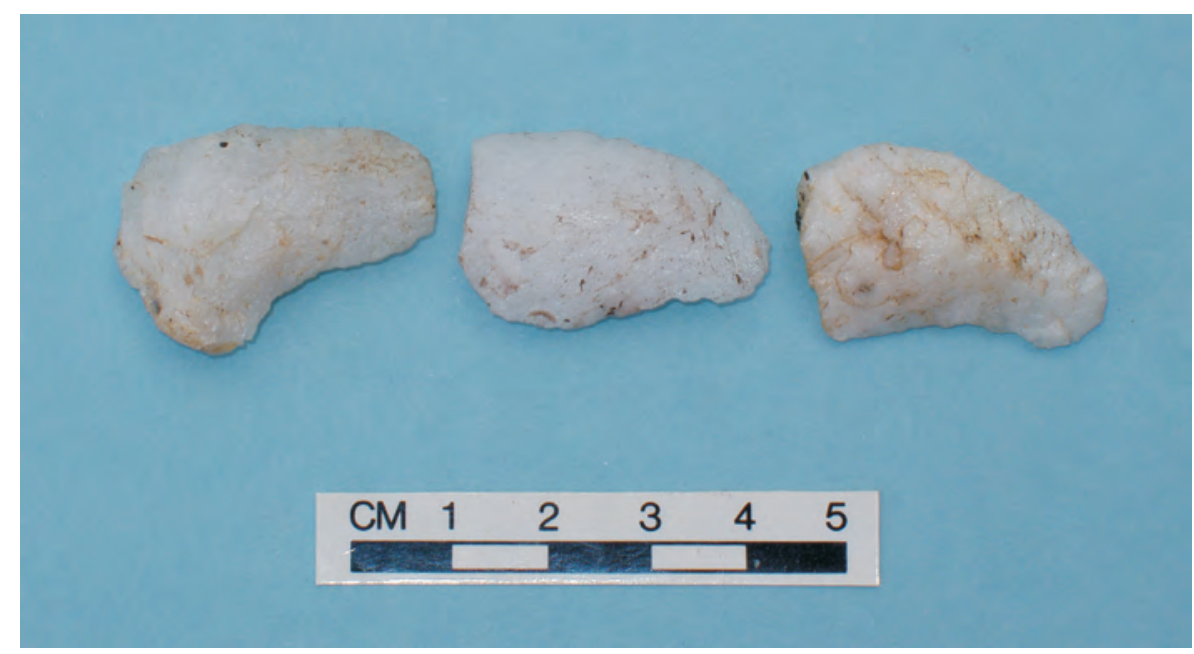

Illus 20 Curved knives, category 4: CAT 2300, 2301, 2304

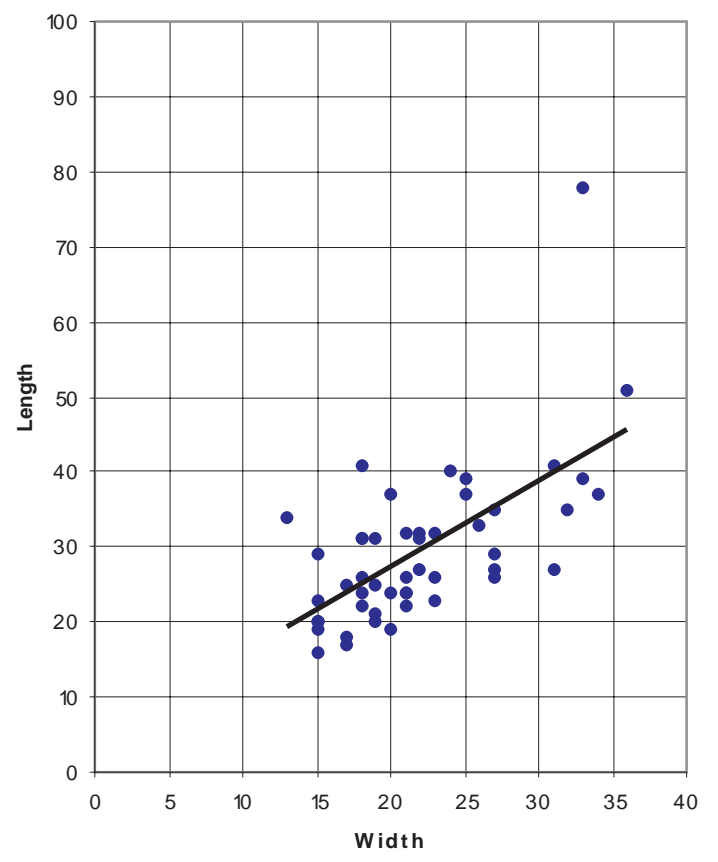

Illus 21 The dimensions of all intact short end-scrapers

form of reduction. The curved knives were recovered from House 2 (Phases 1 and 2) and House 1 (Phase 1), but no sub-type is exclusive to any structure or phase.

\subsubsection{Scrapers}

As mentioned above, scrapers dominate the tool group completely ( $75 \%$ ). A total of 160 scrapers were subdivided into 116 short end-scrapers, eight doublescrapers, 16 side-scrapers, six side/end-scrapers, four other scrapers and 10 scraper-edge fragments.

An end-scraper is defined by having a workingedge approximately perpendicular to the longer of the two dimensions, $\mathrm{L}$ and $\mathrm{W}$ ( $\mathrm{L}$ being the dimension proximal end to distal end), whereas a side-scraper has its edge on the longer of the two dimensions. If $\mathrm{L}>\mathrm{W}$ (elongated blank) the working-edge of the end-scraper will be distal (sometimes proximal) and the edge of the side-scraper will be lateral. If $\mathrm{W}>\mathrm{L}$ (broad blank) the working-edge of the end-scraper will be lateral and the edge of the side-scraper will be either proximal or distal. Or, in short: the edge of an end-scraper is not necessarily at the distal or proximal end, and the edge of a side-scraper is not necessarily at one of the two lateral sides. A short end-scraper is defined metrically by $\mathrm{L}<2 \mathrm{~W}$, whereas long end-scrapers (or blade-scrapers) were defined by $\mathrm{L} \geq 2 \mathrm{~W}$ (Ballin 1996, 54).

The 116 short end-scrapers form a heterogeneous category (av dim: $28 \times 22 \times 12 \mathrm{~mm}$; Illus 21 ), varying in length between $16 \mathrm{~mm}$ and $78 \mathrm{~mm}$ (Illus 22-25; AW 58.6-7, 58.8-9, 58.16, 58.21, 58.23-5, 59.33, 60.8, $60.10-14,60.16,60.19,61.36,61.38-9,61.47-8$, $61.50,61.55,61.57)$. Thirty-three end-scrapers are fragmented, missing either the end opposite the scraper-edge, one lateral side, or corners or central pieces of the working-edge. The vast majority, 88 pieces, are on flakes, while 27 are on indeterminate pieces and one is on an abandoned irregular core (CAT 2214). Twenty-four of the flake blanks are bipolar flakes, 15 are hard-hammer flakes and seven are indeterminate flakes. Practically all scraper-edges are slightly convex to convex, with one being nosed (CAT 2100) and one straight (CAT 2141). Eleven of the scraper-edges are decidedly uneven or slightly denticulated. Most of the endscrapers are simple pieces without ancillary modification, but the lateral sides of seven scrapers have been blunted.

Three short end-scrapers are on outer vein material and consist of a rather unstable mixture of quartz and sandstone; one (CAT 2234) is relatively small (GD 21mm), whereas the other two (CAT 2038, 2065) (Illus 23) are the largest end-scrapers of the assemblage (GD 51-78). As mentioned above, two 


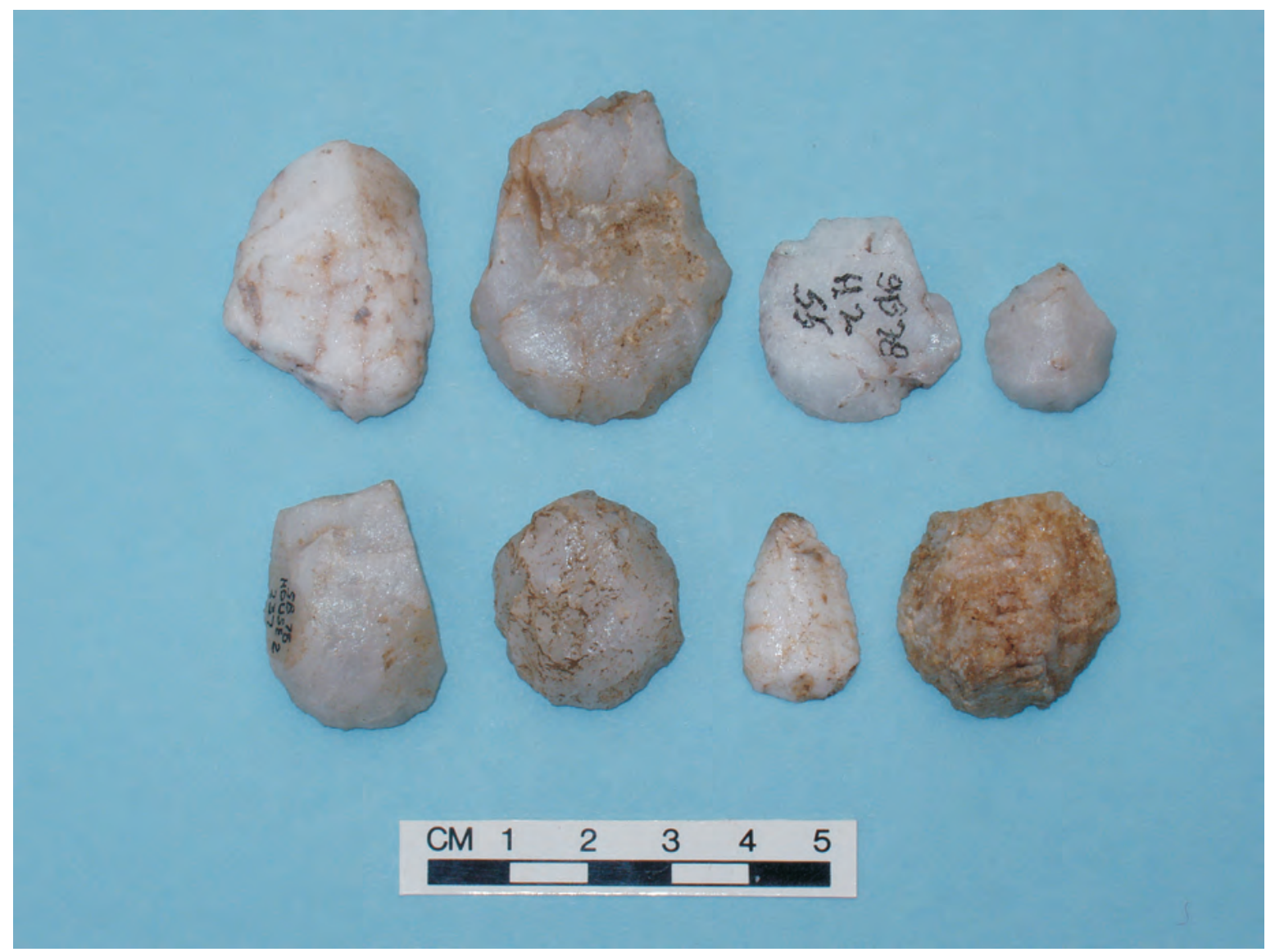

Illus 22 End-scrapers: CAT 2099, 2120, 2127, 2135, 2210, 2221, 2245, 2273

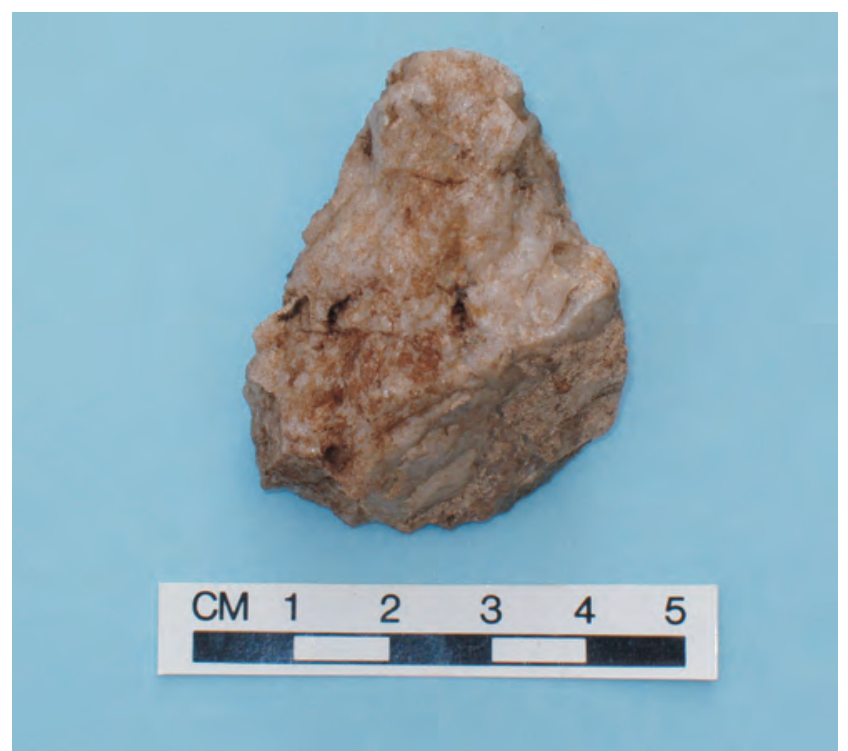

Illus 23 End-scraper, outer vein material: CAT 2038

scrapers were in sandstone and form part of the assemblage of stone artefacts (Rees 1986, 84-5). CAT 2293 is a small end-scraper in felsite (Illus 24); it has an expediently made working-edge at one end, its 'ventral' face or 'under-side' is polished and it has been burnt. It is most likely on a piece of an

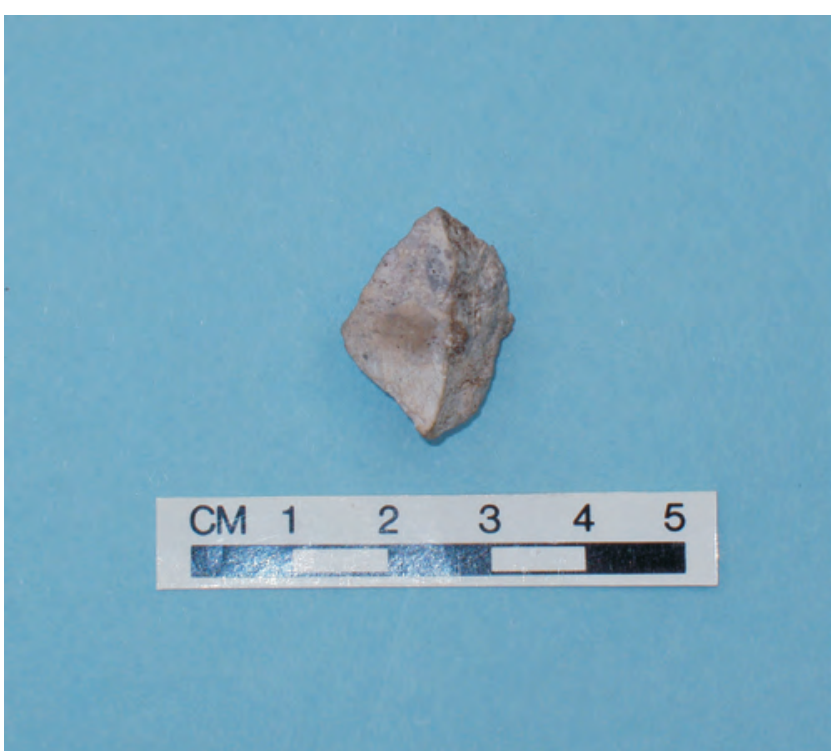

Illus 24 End-scraper, polished felsite: CAT 2293

abandoned (damaged?) axehead, as the piece is too thick $(23 \times 17 \times 11 \mathrm{~mm})$ to have been part of a polished 'Shetland knife'. Due to its burnt state, the piece has lost its original vibrant colours and now appears mottled grey.

The scraper-edge angles vary considerably, but 


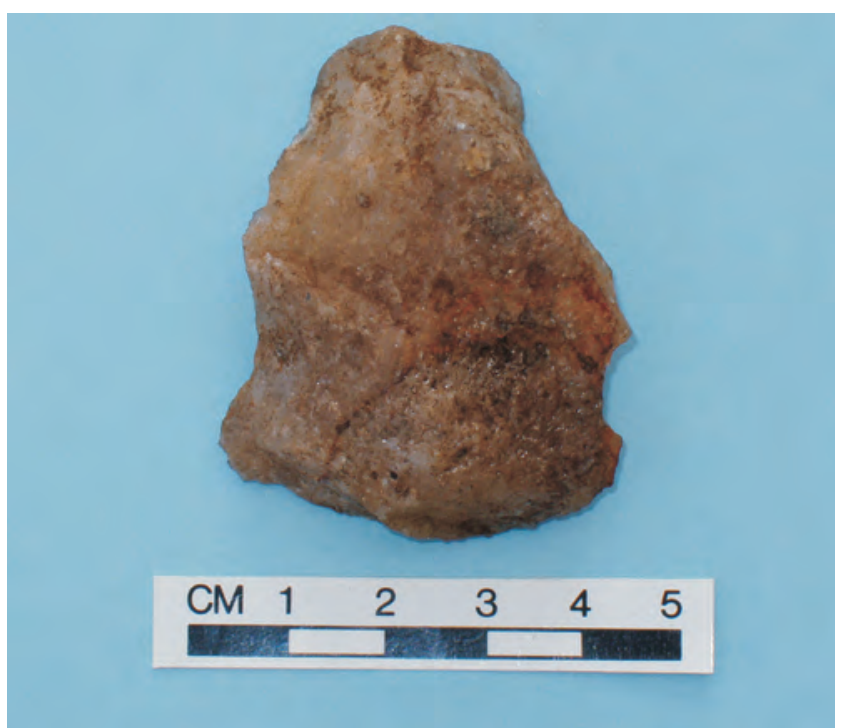

Illus 25 End-scraper, burnt: CAT 2044

most $\left(76 \%\right.$ ) are steep $\left(>65^{\circ}\right.$ ), with $21 \%$ being acute $\left(\leq 65^{\circ}\right)$ and $3 \%$ obtuse $\left(\geq 90^{\circ}\right)$. Scrapers with acute edge-angles $\left(55-65^{\circ}\right)$ have been associated with processing of hides or skin, whereas steep-edged scrapers $\left(70-80^{\circ}\right)$ have been associated with processing of harder materials, such as wood, antler and bone (Broadbent \& Knutsson 1975; Knutsson 1978; Broadbent 1979, 89; Jeppesen 1984; Thorsberg 1986; Juel Jensen 1988, 70; Knutsson 1988, 133). As shown in Illus 26, the edge-angles of the Scord of Brouster end-scrapers correspond approximately to those from the Middle Bronze Age settlement of Bayanne on Yell, Shetland (Ballin, forthcoming c). In Illus 26, the edge-angles from Scord of Brouster form a regular bell-shape with a peak at $71-75^{\circ}$ and, most likely, the majority of those scrapers were manufactured to process harder materials. Compared to the scrapers from Bayanne, it is possible that a slightly higher proportion of the Scord of Brouster scrapers were produced for the working of skin and hides ( $21 \%$ acute scraper-edges versus $8 \%$ ).

\subsubsection{Double-scrapers}

Eight scrapers have a convex, steep scraper-edge at either end. They vary greatly in size (av dim: $30 \times 24$ $\times 13 \mathrm{~mm}$; GD $20-50 \mathrm{~mm}$ ), and the artefact group as a whole has an ad hoc appearance. One blank is an indeterminate piece (CAT 2119), with the majority of the pieces being on a mixture of bipolar and indeterminate flakes. Most of the double-scrapers have their working-edges at opposite ends, more or less symmetrically located on the long axis, whereas CAT 2102 and 2239 are asymmetrical with one end, and the corner of the other end, having been retouched. Two pieces have additional lateral blunting (CAT 2083, 2102). CAT 2119 and 2168 form a small sub-group commonly experienced in quartz assemblages (for example, Bayanne, Lussa River, Shieldaig; Ballin 2002; Ballin, forthcoming c; Ballin et al, forthcoming): one scraper-edge is retouched from one face, and the other edge from the opposite face. Several pieces are missing either lateral sides (for example, CAT 2119), most of one working-edge (for example, CAT 2202; Illus 27; AW 60.17), or corners of one or more working-edges (for example, CAT 2168).

\subsubsection{Side-scrapers}

The assemblage includes 16 side-scrapers (Illus 28; AW 58.3, 59.31, 59.36, 59.41-2, 60.27, 61.42, 61.45, $61.54,61.59$ ), which are generally relatively small (av dim: $13 \times 19 \times 9 \mathrm{~mm}$ ); they vary in length between $15 \mathrm{~mm}$ and $52 \mathrm{~mm}$. Most side-scraper blanks are flakes (nine pieces), but also indeterminate pieces (two pieces) and bipolar cores (five pieces) were used. Two of the flakes are hardpercussion flakes, two are bipolar, and the

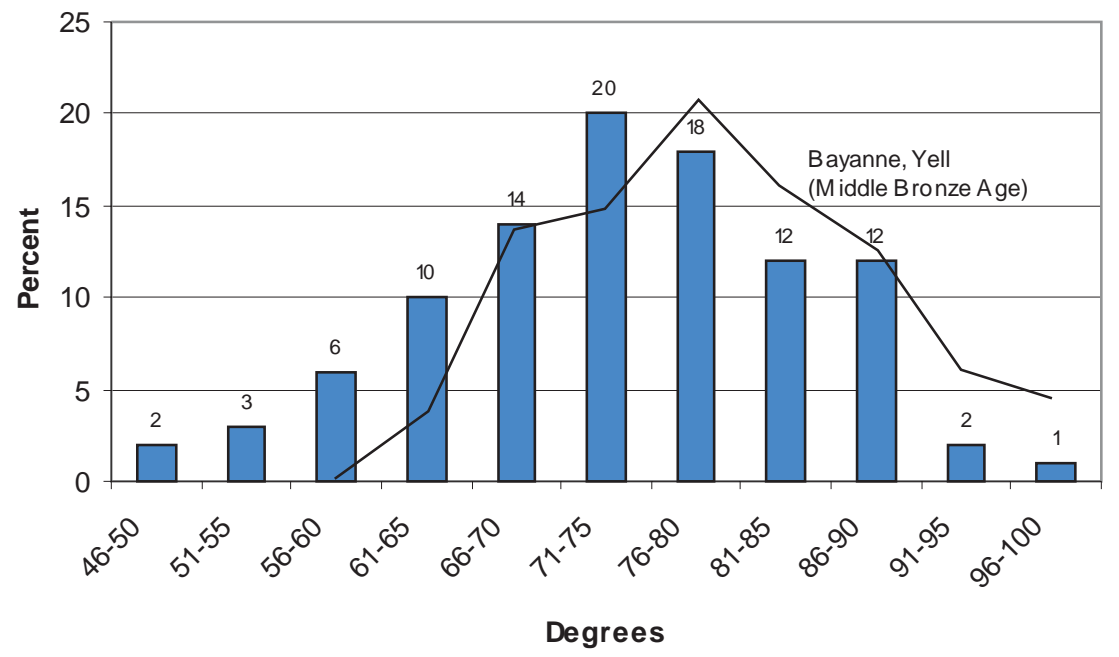

Illus 26 Scraper-edge angles of all short end-scrapers. For comparison, the edge angles of the scrapers from Bayanne, Yell (Ballin, forthcoming d), are shown (curve) 


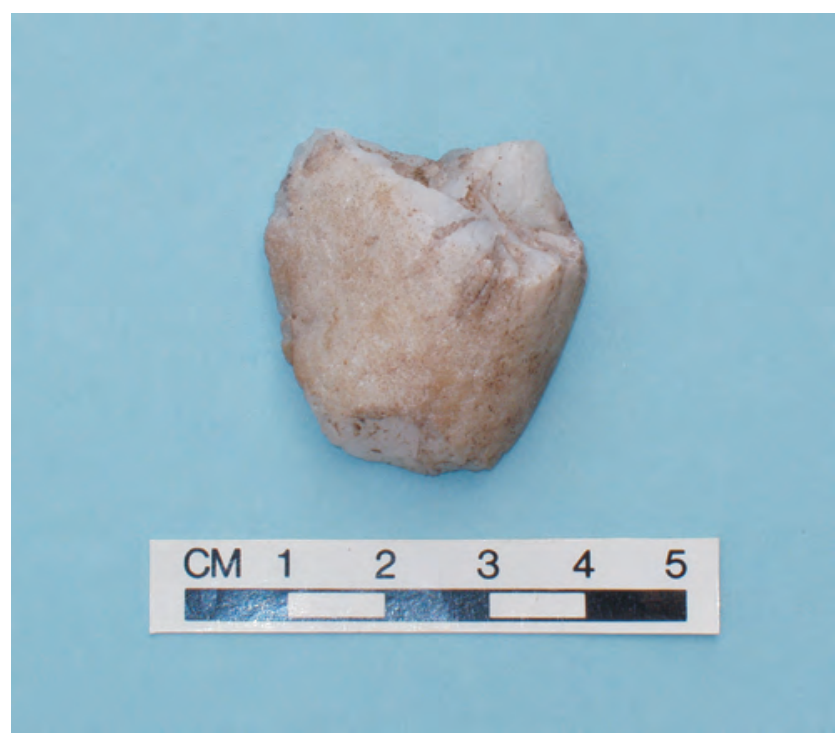

Illus 27 Double-scraper: CAT 2202

remainder are indeterminate. Most of the side-scrapers have one straight, slightly convex or convex working-edge, but CAT 2257 has two opposed scraper-edges, one with normal retouch and one with inverse. CAT 2191 has two opposed retouched edges as well, but only one is a typical steep scraper-edge, whereas the other less robust retouch may represent blunting. At one end, the slightly concave lateral scraper-edge of CAT 2116 curves in a manner suggesting that the broken-off end may have formed an additional working-edge.

\subsubsection{Sidelend-scrapers}

The six scrapers of this category (Illus 28; AW 60.9, $61.49,61.56)$ are less varied than the side-scrapers (av dim: $31 \times 23 \times 12 \mathrm{~mm}$ ). Five of the blanks are fairly regular flakes (two hard-percussion flakes, two bipolar flakes and one indeterminate flake), and one blank (CAT 2113) is a more irregular indeterminate piece. Apart from CAT 2113, they generally have a regular convex scraper-edge at one end, supplemented by a straight to slightly convex lateral working-edge. The more expediently made scraper, CAT 2113, has one straight edge at one end and one straight edge at one lateral side.

\subsubsection{Other scrapers}

Four 'other' scrapers (AW 61.43, 61.52) are defined by not being attributable to one of the formal scraper categories presented above (av dim: $44 \times 33 \times 23 \mathrm{~mm}$ ). In general, the factor rendering these pieces unclassifiable is blank-shape, with two of these scrapers being on irregular indeterminate pieces (CAT 2250, 2276), and the remaining two on irregular cores (CAT 2228, 2269). CAT 2250 is on a triangular chunk of outer vein material, and it has its convex working-edge on one of its three corners. CAT 2276 is an amorphous chunk with a convex scraper-edge at one end; this scraper-retouch alternates and continues along one lateral side, relating the piece to the category of side/end-scrapers. CAT 2228 is an irregular core with a straight scraper-edge on one lateral side, which is no shorter or longer than any of its other edges, making it impossible to define the scraper as either an end- or side-scraper. CAT 2269 is an irregular core with a convex scraper-edge on one pointed corner.

\subsubsection{Scraper-edge fragments}

Ten scraper-edge fragments represent such small parts (av dim: $15 \times 20 \times 8 \mathrm{~mm}$ ) of scrapers that they

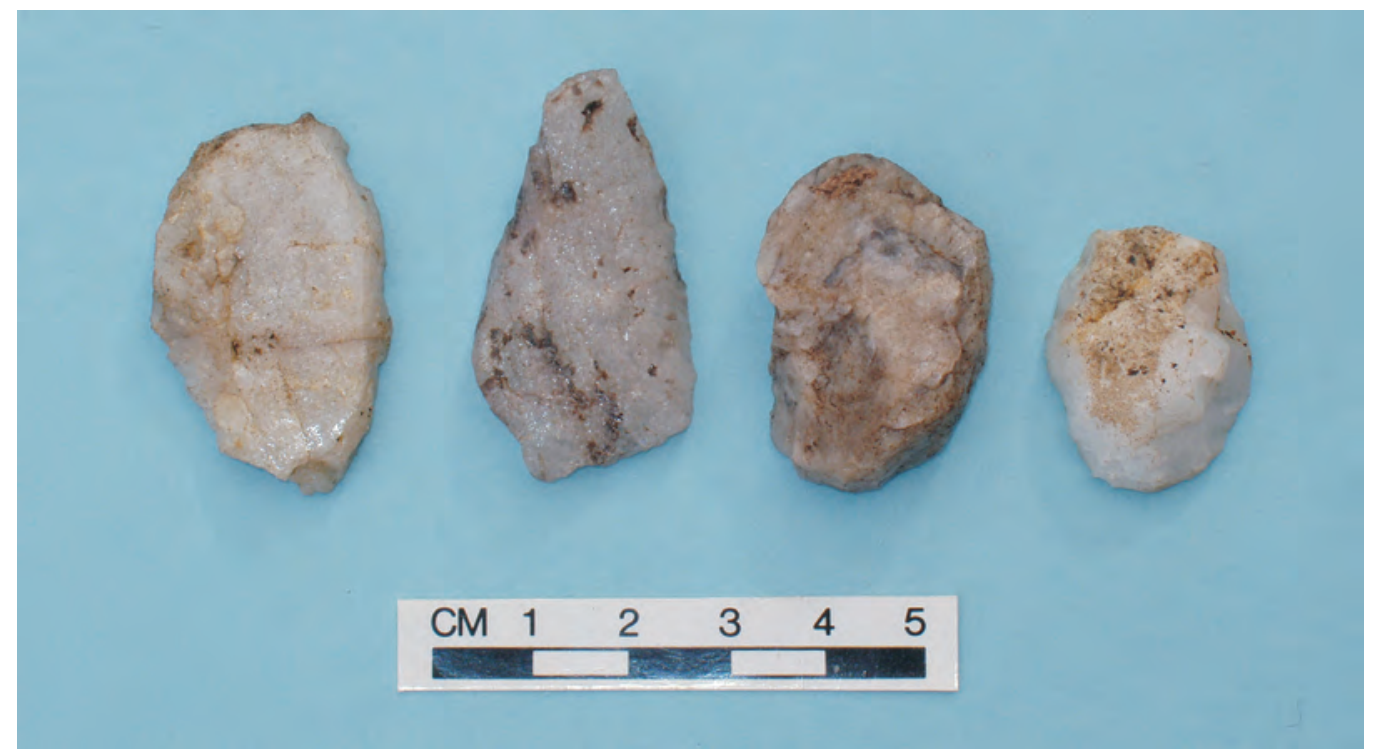

Illus 28 Side-scrapers: CAT 2128, 2295; and sidelend-scrapers: CAT 2204, 2288 


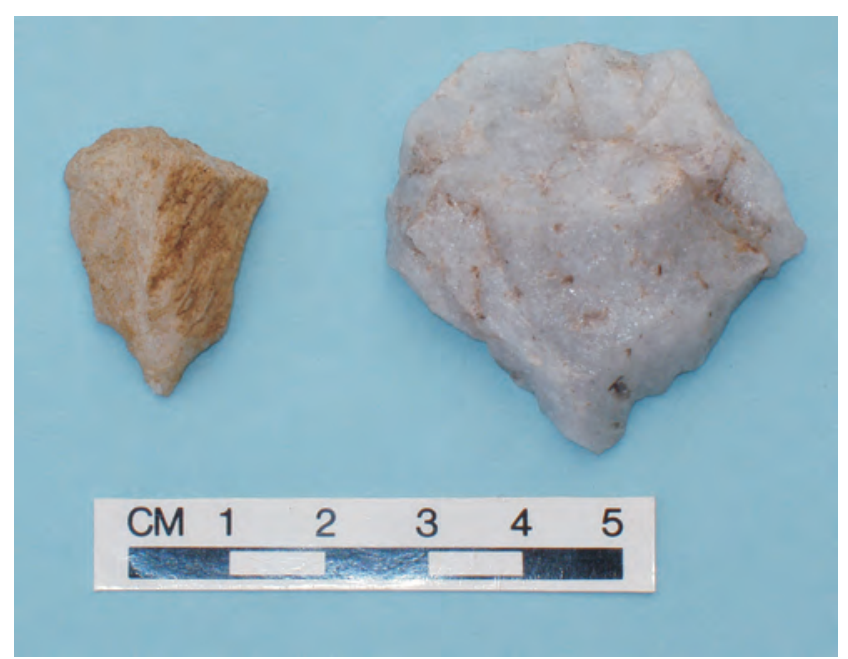

Illus 29 Piercers: CAT 2098, 2260

cannot be defined with more precision. However, most of these broken-off working-edges are fairly narrow and convex, and it is more likely that they are former parts of end-scrapers than side-scrapers.

\subsubsection{Piercers}

Six piercers were retrieved during the excavations of Scord of Brouster, and they form a rather informal, expediently made artefact category; in the description of piercers and their retouch, the following concepts are applied (Ballin 2000):

Normal retouch Retouch initiated from the ventral face (covering the dorsal face)

Inverse retouch Retouch initiated from the dorsal face (covering the ventral face)

Propellar retouch Retouch which is normal on one lateral edge and inverse on the other.

The blanks are four flakes (one bipolar flake and two indeterminate flakes) and two indeterminate pieces, with tips formed on whatever end or corner the knapper found suitable. The piercers vary greatly in shape and size (av dim: $34 \times 29 \times 15 \mathrm{~mm}$; GD 27-50mm), and the general appearance of these pieces indicates random selection of blanks. As noticed in connection with the author's analysis of other quartz assemblages (for example, Bayanne; Ballin, forthcoming c), the two retouched lateral sides of a number of piercers meet at almost right angles (CAT 2064, 2203, 2260), with three piercers having more acutely pointed tips (CAT 2084, 2098, 2224) (Illus 29). In three cases (CAT 2084, 2203, 2224 ), the outermost part of the tip has broken off. The tips of all six piercers have been manufactured by the use of normal retouch only, with no piercer tips having been made by the application of inverse or 'propellar' retouch.

\subsubsection{Truncated piece}

One small hard-hammer flake (CAT 2176) $(19 \times 12 \times$ $5 \mathrm{~mm}$ ) has a straight oblique truncation at the distal end. The retouch of the piece is slightly uneven and may be blunting. The edge opposite the modified area is sharp. Most likely, CAT 2176 is a small expediently made knife.

\subsubsection{Notched pieces}

Two notched pieces were recovered during the archaeological investigation of the site. CAT 2173 is a fragment of an indeterminate flake with a retouched notch in one lateral side; the chord of the notch is $c 10 \mathrm{~mm}$. CAT 2054 is a fragmented, possibly burnt, indeterminate piece with three notches distributed along the circumference. One notch may have been formed by retouch or 'rubbing', whereas two are plain single-removal notches; the chords vary between $4 \mathrm{~mm}$ and $7 \mathrm{~mm}$. The function of these pieces is uncertain.

\subsubsection{Denticulated pieces}

A number of tool types are defined by one or more series of teeth, namely denticulated pieces, saws and serrated pieces. Denticulates are defined as pieces with coarse denticulation formed by the working of either contiguous notches or by the detachment of small flakes; saws are intermediately serrated pieces, the teeth of which are formed by two or more small removals on either side of each tooth; and serrated pieces are defined as mostly straight-sided blanks with one, or occasionally both, lateral edges finely serrated by the removal of a single chip on either side of each tooth (Healy 1996, 76).

Two relatively small denticulated pieces were found at Scord of Brouster (av dim: $28 \times 19 \times 14 \mathrm{~mm}$ ). Denticulated pieces are frequently recovered from later prehistoric contexts (for example, Humble, forthcoming), and it is uncertain whether they have a specific function, or whether they may represent an amalgamation of several functional groups (various expedient tool forms, and plain core types, such as flaked flakes; Ashton et al. 1991). CAT 2090 is a fragment of an indeterminate piece with relatively fine denticulation along one edge (three surviving teeth) and may have been a denticulated scraper. CAT 2258 (Illus 30; AW 58.2) is a fragmented indeterminate piece with cruder denticulation along the entire circumference (six surviving teeth) and is most possibly a small core.

\subsubsection{Pieces with invasive retouch}

The assemblage includes seven pieces, mainly fragments, with invasive retouch. Two pieces (CAT 2080, 2286) are large (av dim: $62 \times 28 \times 14 \mathrm{~mm}$ ) and 


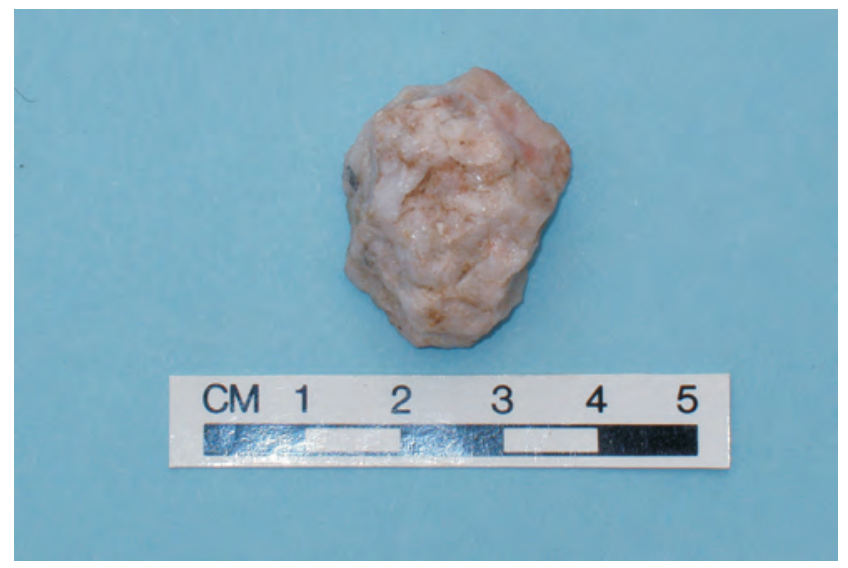

Illus 30 Denticulate: CAT 2258

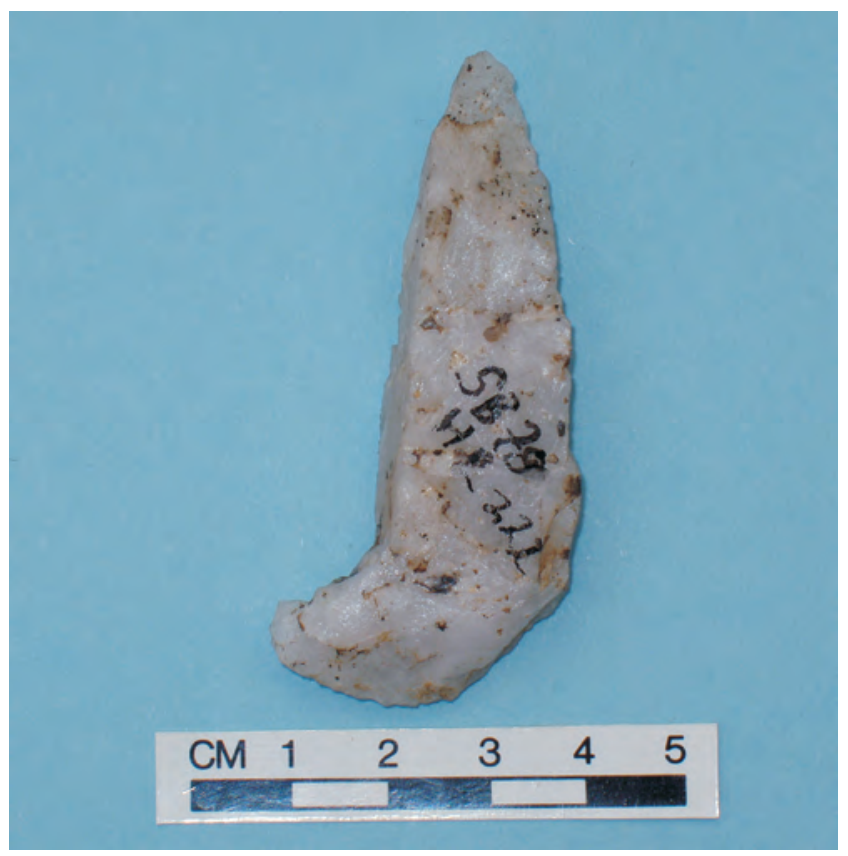

Illus 31 Large piece with invasive retouch: CAT 2080

five pieces (CAT 2050, 2092, 2114, 2124, 2178) are small (av dim: $28 \times 19 \times 8 \mathrm{~mm}$ ) (Illus 31; Illus 32; AW 59.29-30). Two of the small pieces (CAT 2114, 2178) are flakes with limited unifacial invasive retouch along various edges; it is not possible to say whether they are regular, relatively plain tools (for example, small knives with sporadic invasive blunting or sharpening of edges) or fragments of early-stage rough-outs for more elaborate tools (for example, arrowheads or curved knives). The two large objects (CAT 2080, 2286) are both fragments of bifacial pieces and they both split along the long axis. They are thick, obviously unfinished pieces, and the neatly rounded base of CAT 2080 suggests that they may be rough-outs for relatively large leaf-shaped points. Three small fragments have both faces completely covered by fine invasive retouch and are probably fragments of completed leaf-shaped points (CAT 2092) or rough-outs for leaf-shaped points (CAT 2050, 2124). They are most likely arrowhead base fragments.

\subsubsection{Pieces with edge-retouch}

This artefact category consists of 15 pieces, which form a diverse group, differing considerably in size and shape $(27 \times 20 \times 10 \mathrm{~mm}$; GD $18-41 \mathrm{~mm})$. Two are based on indeterminate pieces, three on abandoned bipolar cores and the remainder on flakes; one flake blank is bipolar, three are hard-percussion-flakes and six are indeterminate flakes. Twelve of the 15 retouched pieces are fragments of larger tools. The functions of the artefacts are uncertain.

\subsubsection{Fabricator}

One rod-shaped piece (CAT 2274) has been classified as a fabricator (AW 60.30). The blank is a long indeterminate piece with a triangular cross-section $(71 \times$ $20 \times 18 \mathrm{~mm}$ ), and one end and one lateral side broken off. The surviving end was shaped to form a point by retouching and merging the three lateral sides of the rod. This point is battered and abraded from repeatedly striking hard objects. One lateral edge adjacent to the broken-off end has been retouched, and it is possible that the piece originally had two workingends.

\subsubsection{Hammerstones}

Three hammerstones (AW 61.37) were recovered from Scord of Brouster (av dim: $54 \times 50 \times 42 \mathrm{~mm}$ ). They are all unevenly rounded, with severely

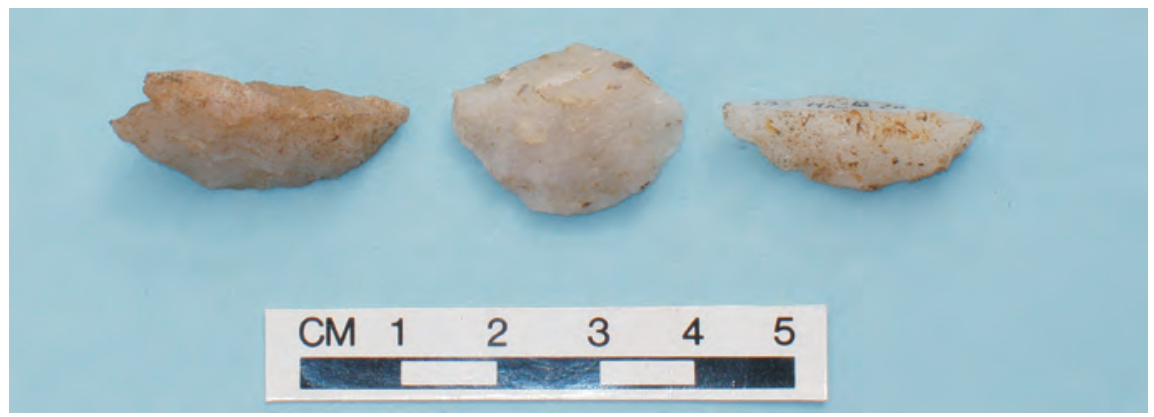

Illus 32 Small pieces with invasive retouch: CAT 2050, 2092, 2124 
battered edges and points. Unlike the 'archetypal' hammerstone, which would usually have one or two specialized working-ends, every protuberant area of CAT 2068, 2213 and 2266 has been crushed. Generally, three or four crushed points can be identified, and every ridge connecting these points has been battered as well.

\subsection{Technology}

The operational schema of a lithic industry may be subdivided into a sequence of logical stages (Eriksen 2000, 81; Ballin, forthcoming c), such as: acquisition of raw material, core preparation, blank production and secondary modification. Stage 3 may include a number of blade/flake series, separated by rejuvenation of platform, platform-edge and core sides, and the core may develop from blade core, over flake core to bipolar core (Ballin, forthcoming c). As $99.8 \%$ of the present assemblage is quartz, the following analysis will focus mainly on the operational schema responsible for the production of quartz blanks and tools.

\subsubsection{Acquisition of raw material}

As discussed in Section 3.1 - Raw materials (above), quartz was acquired from a number of local and non-local sources. Many of the artefacts have parts of the original rock matrix adhering to them. Most of this material is sandstone, suggesting that much of the quartz assemblage was quarried from veins in the local Sandness Formation. Chunks from the outer parts of these veins (pieces in sandstone/quartz mixtures or pure sandstone 'decortication' rubbish) were found in all three houses, but the sub-assemblage from House 3 consists almost entirely of this sort of débitage, suggesting that 'decortication' of quarried quartz may have dominated the lithic activities of this structure. As removal of excess weight from quarried quartz plates or nodules mostly took place at or near the quarry or vein (Powell 1965), this also suggests that the vein in question was in close vicinity to the settlement.

A small proportion of quartz has feldspar or steatite/chlorite adhering to it, testifying to the exploitation of additional veins. The feldspar indicates the use of a quartz vein in granite or gneiss bedrock, with the closest sources being at $6-10 \mathrm{~km}$ distance, either to the south (the Sandsting Complex) or to the east (east of the Walls Boundary Fault) (Mykura 1976, figs 9-10). Steatite and chlorite both derive from the metamorphic areas of Shetland. The nearest reported source of steatite is at a distance of $c 20 \mathrm{~km}$, on Burra Isle (Whittle 1986 , 74), but other authors (Mykura 1976, plate IV; Woodland 1979) indicate a small serpentinite source immediately east of the Walls Boundary Fault, which may include some steatite as well as chlorite (approximately $10 \mathrm{~km}$ distance).
Due to the burnt state of much of the quartz, it is difficult to assess the outer surfaces of the artefacts, and an actual attribute analysis was not carried out. It is, however, the author's impression that pebble quartz was collected as well, as demonstrated by many pieces with abraded cortex, and pebble sources possibly supplied the same amount of raw quartz as the various quartz veins. Most likely, quartz pebbles were collected along the shores of the nearby Gruting Voe.

\subsubsection{Core preparation}

The platform core:bipolar core ratio (47:53) of the assemblage defines an industry based on platform technique, with bipolar technique applied to exhaust abandoned platform cores completely. In comparison, the mainly bipolar industry of Lussa River (Ballin 2002) has a ratio of 15:85. The technological attributes of the various core types (see Section 3.3Cores, for description of characterization) suggest the sequential transformation of one core type into another, with single-platform cores representing the first stage of the reduction sequence. Most likely, single-platform cores would be transformed into cores with two platforms at an angle when their shapes made this transformation necessary, and these dual-platform cores might then later be transformed into irregular cores by the formation of a third platform. When a platform core had become too small to handle, it would in most cases be exhausted completely by the application of bipolar technique.

As touched upon above, the first step of core preparation at Scord of Brouster was the removal of adhering rock, or cortex, and poor-grade outer quartz. The masses of quartz-with-sandstone suggest that this process to a large extent took place in or around the three houses, completely dominating the lithic activities of House 3. As part of this 'decortication' process, rough-outs for singleplatform cores were manufactured. The rough-outs were characterized by the existence of a mainly plain platform and, usually, two bilateral crests or guide ridges. No preparation flakes were recovered in connection with the excavation of the site, but two single-platform cores (CAT 2039, 2059) retain parts of crests at their apexes. As a large number of flakes, as well as approximately half of the single-platform cores, have trimmed platform-edges, it is most likely that modification of the platform-edges was standard procedure before commencement of actual blank production.

\subsubsection{Blank production}

The industry of Scord of Brouster focused entirely on the production of slightly elongated flakes, with proper parallel-sided blades being absent. The first flake series of a single-platform core would be commenced by the detachment of one of its crests, but in many cases this action was unsuccessful. The 
fact that the two conical or sub-conical cores (CAT 2039, 2059) have retained parts of crests at their apexes is evidence that insufficient force was applied, and that the resulting (crested) flakes were too short. The two handle-cores, or keeled cores (CAT 2227,2290 ), were both abandoned as the attempt to detach the terminal crest (an extension of the keel) resulted in the development of large hinge-fractures.

With quartz flaking as unpredictably as it does (partly demonstrated by the problems experienced in the attempts at detaching the crests), it is to be expected that adjustment, or rejuvenation, of the cores would become urgent at a relatively early stage. The lack of complete or partial core tablets, as well as the fact that the vast majority of all cores have plain unfaceted platforms, suggest that core rejuvenation by the detachment of platforms was not part of the operational schema. Most likely, adjustment of obtuse platform-edge angles and irregular core-sides was carried out by detaching entire core-sides ('flaking fronts'), as documented in the operational schema of the Southern Scandinavian Brommian Culture (Andersen 1972, 25-7). In the Brommian Culture, core tablets are exceedingly rare, whereas large thick core-side flakes are common.

When a core could no longer be adjusted within the framework of a specific core-type, the core would be re-shaped to allow continued reduction. In the case of single-platform cores, this would generally happen by the addition of a second platform-edge almost at a right angle to the first. At this stage the core would acquire an almost cubic shape. Later, cores with two platforms at an angle might be transformed into irregular amorphous cores with three or more platforms. The final stage would be the total exhaustion of small platform cores by the application of bipolar technique.

The operational schema presented above is entirely opportunistic, and if the quartz knappers of Scord of Brouster found it appropriate to skip one or more stages, they would do so. If, for example, the original quartz nodule was small, a bipolar approach may have become appropriate at an earlier time. Thus, a single-platform core may have been transformed into a bipolar core without the intermediate steps of dual-platform cores and irregular multi-platform cores. Likewise, cores could have been abandoned at every step if, for example, damage prevented adjustment and further production.

\subsubsection{Secondary production}

At Scord of Brouster, modification of the blanks was carried out in two ways: either by edge-retouch or by invasive retouch. Most of the tools (for example, scrapers, piercers, truncations, notches and denticulates) were manufactured by exclusively retouching one or more edges. Arrowheads and knives were mainly shaped by invasive retouch, with the site's leaf-shaped arrowheads and curved knives owing their general morphology entirely to the use of invasive, bifacial retouch. One scale-flaked knife (CAT 2243) was formed by a combination of edgeretouch (the blunted 'back') and invasive retouch (the straight cutting-edge).

Curved knife CAT 2299 retains an unmodified, superficially burnt area in the central part of either face, whereas the peripheral zone of the piece which appears unburnt - has been modified by the bifacial detachment of thin flakes. This suggests that some quartz blanks may have been subjected to heat-treatment. Experiments (Crabtree \& Gould 1970, 194; Eriksen 1999) have shown that flakes from heat treated silica nodules tend to become thinner than flakes from raw nodules, and it is possible that at Scord of Brouster blanks were heat-treated mainly as part of the production of bifacial implements (thinning). The fact that many implements (for example, many scrapers) had been burnt after their modification into tools indicates that heat treatment is not the main cause of the high burnt quartz ratio of this assemblage. 


\section{Discussion}

\subsection{Quartz distribution and activities at Scord of Brouster}

In this chapter the débitage, core and tool distribution are discussed, as well as the activities suggested by the scattering of artefacts. First, the internal distribution patterns of the three houses is dealt with, followed by the distribution across the three houses. As the principles of recovery and recording of finds differ from house to house, and between layers, the author was incapable of producing standardized distribution maps (point and contour maps) and, in the following discussion, reference will be made to Whittle's general distribution maps (Whittle 1986, 85-90). For a detailed discussion of the three structures see Whittle's monograph on the Scord of Brouster (Whittle 1986).

\subsubsection{House 2 (Whittle 1986, figs 68-9)}

This structure is approximately kidney-shaped, includes two recesses, and has no obvious entrance. The fact that individual finds were recorded in a variety of ways (exact 3D-plotting, per quarter of square metre and per sector) makes it difficult to get a general picture of the distribution of lithic artefacts. However, it is the author's impression that the distribution pattern is more or less the same throughout Phases 1 and 2 (pre-house, construction and use-phases) of House 2.

Generally, most quartz artefacts were found in the western half of the house, with fewer finds in the two central sectors, and even fewer in the two eastern sectors and in the north-east recess (Illus 33). Though the majority of finds from Phases 1 and 2 were recorded per sector, the more precisely recorded and plotted finds suggest that the tools were mostly found in the open area around Hearth F4, a possible central fireplace. The cores were partly recovered from areas characterized by knapping and partly from more peripheral areas. Cores from prehistoric sites are frequently found in the peripheral parts of settlements or houses, as they may have been removed ('tossed') from the central zone of sites as part of preventive maintenance (Binford 1983,189).

The individually plotted quartz objects of Phases 1 and 2 indicate that the northern (F1) and north-eastern (F2/3) recesses were almost, but not entirely, devoid of finds. The larger (F2/3) of the two recesses is approximately $2 \mathrm{~m}$ long and may have been a sleeping area (cf distribution of lithic finds in the Dalmore house; Ballin, in prep b). The function of the northern recess is less certain. The quartz distribution in Phase 3 (decay) is probably linked to the use of the location after its general abandonment. Lithics were found evenly scattered across the interior of House 2, but also across the wall tumble and outside the house.

The above distribution patterns only yield little and general information on activities involving quartz use. Knapping was mainly carried out in the western half of the structure, with some knapping

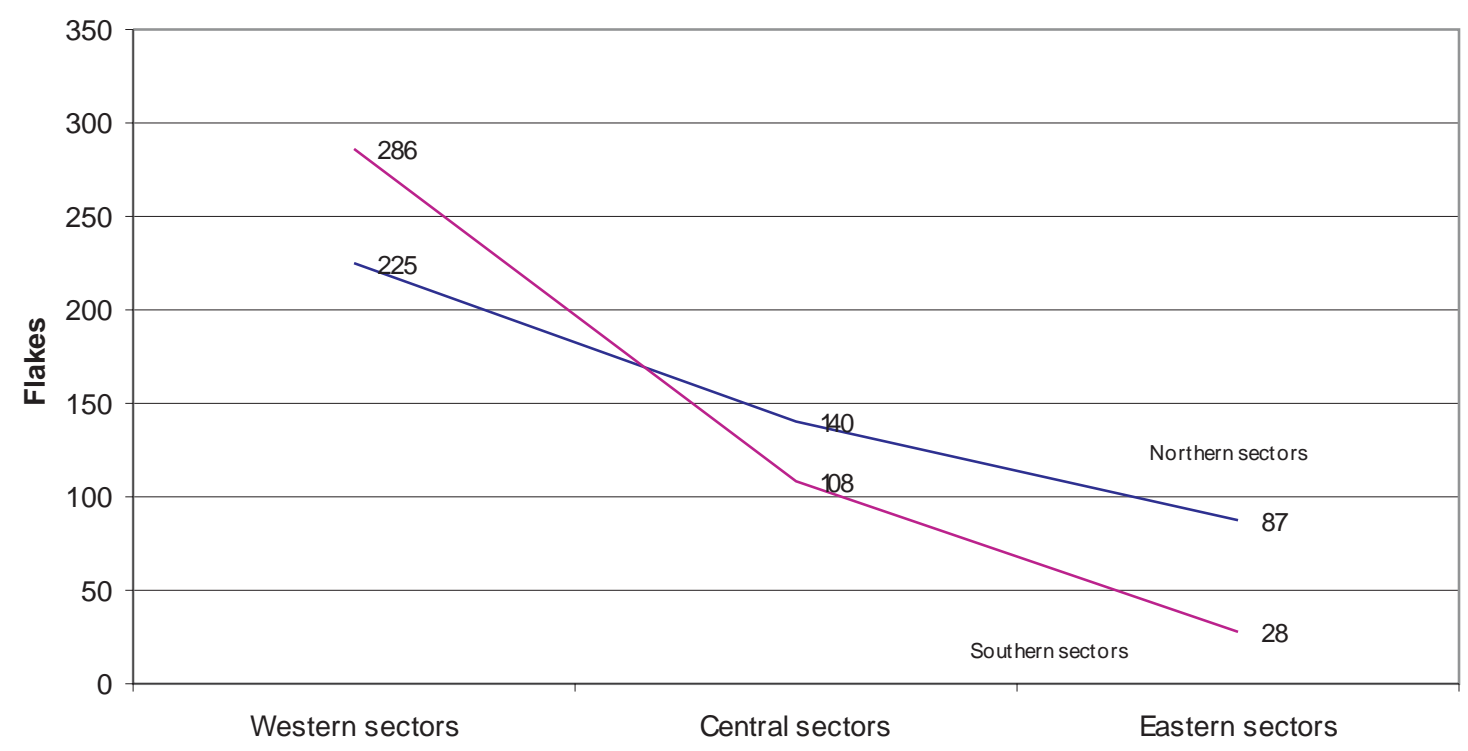

Illus 33 House 2. The distribution of quartz flakes from west to east 
and tool use taking place around the central hearth. Clearance of rubbish appears to have taken place, but mainly in the form of preventive, not post hoc, maintenance, leaving large amounts of lithic waste cluttering the floor space. Two areas, Recesses F1 and F2/3, have been kept relatively free of rubbish, and the size of Recess F2/3 would have allowed use as a sleeping area.

\subsubsection{House 1 (Whittle 1986, figs 70-4)}

This building is oval, with six recesses, and orientated approximately north-west/south-east; it has an entrance to the south-east. In Phase 1 (pre-house), most of the quartz waste, cores and tools were scattered across the southern half of the building, and a large concentration of quartz artefacts was deposited under the southern wall, outside Trench F10, and a small concentration in Recess 1 to the north-east. The quartz distribution was associated with three hearths: F1 in Recess 4 to the south-west, central hearth F2 and the more complex hearth F4-8 in Recess 1 to the north-east. No areas were specialized, and quartz knapping and tool use seem to have taken place throughout the space occupied by lithic debris.

In Phase 2 (main use-phase), there was less quartz and it had a wider distribution. The centre of the building was more or less free of clutter, with most of the lithic finds deriving from either areas along the northern wall, or from a zone just inside the southern orthostats. In the northern half, most of the quartz was found in Recess 6, and small concentrations in Recesses 1 and 2. In the southern half, most of the quartz was recovered from within, or just outside Recess 4, and several pieces from the area surrounding Orthostat 8 (separating Recesses 3 and 4). Again, quartz waste, cores and tools were mixed, with no apparent separation of, for example, knapping floors and areas for tool use. There were a number of hearths (F15 being a central fireplace), or ashy patches, along the central long axis of House 1, the area kept free of lithic waste.

It is possible that some recesses were workspaces, and others sleeping areas, but the quartz concentrations were not dense enough to have prohibited any of the recesses from having been sleeping areas. However, Recess 6 was also associated with a central concentration of coarse stone tools (mainly ard points), suggesting that this particular part of the structure may have been a working area, and the distribution of small scoops and fireplaces in Recesses 1, 5 and 6, makes Recesses 2-4 most probable as 'private quarters' or sleeping areas. In the case of dwellings, traffic in and out of buildings frequently results in a trail of lithic debris in the entrance area, and a solid concentration immediately outside the doorway (cf Dalmore; Ballin, in prep b). An entrance trail and exterior concentration were not identified in connection with House 1, Phase 2.
In Phase 3 (decay), the majority of the worked quartz pieces were found along the walls of the structure, with only a small number of lithic artefacts deriving from the central parts of the building. The discussion of distribution patterns is limited by the retrieval methods, with the findspot of some quartz artefacts being recorded precisely, and some only by house sectors (each $c 2-3 \times 2-3 \mathrm{~m}$ ). The individually plotted artefacts indicate a concentration in one corner of Recess 1, and the sector-recorded finds suggest the presence of one or more concentrations in the eastern quadrant (possibly the Recess 1 concentration identified by the individually plotted pieces), and outside the entrance. The latter imply either the presence of an entrance trail or a so-called 'door-dump' (Binford $1983,151)$, where rubbish was deposited in connection with post hoc maintenance.

The distribution of quartz does not allow a more detailed analysis of the activities in House 1. Considerably more quartz blanks, cores and tools were produced during Phase 1 than during Phase 2, but as the exact duration of the individual phases is unknown, it is not possible to infer that more quartz implements were produced and used per time unit (for example, per year) in Phase 1. No areas appear to have been used particularly for primary production or tool use, as blanks, cores and tools were generally mixed. The distribution of lithic debris was more widespread in the pre-house phase than in the main occupation phase, with the quartz of Phase 2 respecting and avoiding the central space. Knapping and tool use seem to have taken place mainly in, or just outside, the various recesses (at the Middle Bronze Age site of Bayanne on Shetland no knapping took place inside the dwellings, but only outside the houses or in work-sheds; Ballin, forthcoming c). A low local density of lithic and stone rubbish suggests that one or more of Recesses 2-4 may have been sleeping areas, with the remaining recesses possibly having been used as work-spaces. The finds of the abandonment phase were not numerous enough to allow detailed inference, but the small concentration of quartz in a corner of Recess 1 , and another possibly outside the entrance, suggest that even at this stage of disintegration the structural elements of the building were respected in the organization of activities.

\subsubsection{House 3 (Whittle 1986, figs 75-6)}

The lithic finds of this structure were too few in number to allow definition of internal spatial patterns.

\subsubsection{Lithic artefacts and activities}

The sub-assemblages from Houses 1 and 2 were substantial, whereas the material from House 3 was numerically limited: 5688 lithics (or 59\% of the total 
Table 4 Houses 1 and 2: the proportions of the main tool categories

\begin{tabular}{lcccc}
\hline & & Numbers & & \multicolumn{2}{c}{ Percentage } \\
& House 1 & House 2 & House 1 & House 2 \\
\hline $\begin{array}{l}\text { Arrowheads } \\
\text { Knives (incl truncated }\end{array}$ & 2 & 0 & 2 & 0 \\
piece) & 7 & 7 & 6 & 77 \\
$\begin{array}{l}\text { Scrapers } \\
\text { Piercers }\end{array}$ & 91 & 69 & 75 & 2 \\
$\begin{array}{l}\text { Notches and } \\
\text { denticulates }\end{array}$ & 4 & 2 & 3 & 2 \\
$\begin{array}{l}\text { Pieces with various } \\
\text { retouches }\end{array}$ & 2 & 2 & 2 & 10 \\
$\begin{array}{l}\text { Fabricators and } \\
\text { hammerstones }\end{array}$ & 3 & 9 & 10 & 1 \\
TOTAL & & 1 & 2 & 100 \\
\hline
\end{tabular}

collection) were recovered from House 1; 3772 lithics (or 39\%) from House 2; and only 227 lithics (or $2 \%$ of the total) from House 3 . The proportions of the three main categories - débitage, cores and tools - were roughly the same in Houses 1 and 2, with débitage making up approximately $97 \%$ of all lithic artefacts, cores $c 1 \%$ and tools $c 2 \%$. In House 3 , débitage constituted $99 \%$, and cores and tools each $c$ 0.5\% (one single-platform core and one retouched piece).

As shown in Table 4, the tool spectra of Houses 1 and 2 were almost identical. In both sub-assemblages, scrapers make up approximately threequarters of all tools, with retouched pieces being the second most common tool group (10\%). The relatively large number of curved knives makes knives comparatively numerous in both houses (6-8\%). All other tool categories represent proportions of between $0 \%$ and $2 \%$ of the two sub-assemblages.

In terms of function, the arrowheads were produced either for defensive or hunting purposes; the two types of knives may represent different functional categories: the scale-flaked knife and the truncated piece, with their straight edges, would have been suitable for traditional cutting work, for example, butchering, whereas the curved knives may form a separate group of specialized implements the precise function of which is presently unknown. The analysis of scraper-edge angles (above) suggests that the scrapers were manufactured mainly for the processing of harder materials, such as bone, antler and wood. The fact that half of the piercers have almost blunt tips and the other half acutely pointed tips indicate that these may have been used for a variety of tasks - the blunt, more robust pieces may have been involved in the drilling of harder materials, and the more acutely pointed ones may have been used to penetrate softer materials, such as leather and skin. The notched, denticulated and retouched pieces probably represent a number of different functions.

The leaf-shaped arrowhead CAT 2297 from House 1 is a rough-out and proves that arrowheads were produced on site. CAT 2080 (House 2) is most probably a pre-form of a large leaf-shaped arrowhead broken during production, and CAT 2050, 2092 and 2124 (Houses 1 and 2) are probably base-fragments of leaf-shaped arrowheads. They may have broken during use (hunting?) in the field, and the arrows, with the bases of the points still attached to the arrowshaft, were brought back to the settlement for retooling (Keeley 1982).

The number of functions covered by the lithic tools from Houses 1 and 2, and the similarities between the two sub-assemblages, support the notion of the structures as being permanent, or semi-permanent (seasonal), dwellings (cf Whittle 1986, 137). It is a well-known fact that in prehistoric times many, or most, tools were made in perishable materials, and a large number of the lithic tools may have been used for the manufacture of tools and other products in organic raw materials (wooden bowls and spoons, bone piercers and points, clothing and adornments, fish-traps, nets, bows and arrows, shafts and handles and so on). No such objects were recovered at Scord of Brouster, but the excavation of prehistoric settlements from submerged or wetland sites (for example, Oakbank Crannog, Loch Tay, Perthshire; Dixon \& Cavers 2001, 78-9) demonstrates that implements in organic materials usually made up a large proportion of the tools employed by prehistoric man.

The lithic assemblage from House 3 (practically all from the main Structure 3a) defines this unit as functionally different. As demonstrated previously (Fischer et al 1979, 12), lithic reduction produces much debris in a short span of time. In one experiment at the Lejre Archaeological Research Centre, Denmark, almost 20,000 flakes were manufactured in 2 hours and 40 minutes, and the 170 flakes and indeterminate pieces from House 3 may represent a single brief knapping event. The small amount of lithic rubbish probably represents one of three scenarios: either House 3 was in use for a very short period, it was thoroughly cleared out, or the structure may have had a specialized function (or a combination of the three). The composition of the débitage category supports the latter option. 
The sub-assemblage from House 3 includes the same proportion of flakes as Houses 1 and 2 (on average $77 \%$ of the débitage), but fewer chips (3.5\% against $c$ 16-20\%) and many more natural pieces of quartz (c 20\% against $c$ 3-6\%). As suggested above, the flakes of House 3 may derive from a single knapping event, and the large amount of natural quartz is probably a byproduct of the decortication of relatively large numbers of raw quartz blocks. Most of the natural quartz has sandstone adhering to it, and this material had to be removed before the collected quartz was suitable for schematic knapping. The decortication of raw quartz blocks would not produce many chips; they would largely be produced as part of the primary and secondary production sequences. The decorticated core roughouts were most probably removed from the building for further reduction elsewhere.

This suggests that House 3 may have had a workshop-like function, though the internal structure of the building, with a central hearth and five recesses or cells, corresponds to the structure of other contemporary Shetland dwellings (for example, Calder 1956). As the radiocarbon dates indicate a possible chronological overlap of the use-phases of Houses 1 and 2, but none between House 3 and the other buildings, it is uncertain to which settlement the House 3 workshop was linked.

\subsection{Dating}

The assemblage appears homogeneous, typologically as well as technologically. It includes few strictly diagnostic elements, but two leaf-shaped arrowheads suggest an early Neolithic date. (Some analysts sub-divide the Neolithic period into two phases: the early and late Neolithic-defined, respectively, by leaf-shaped points/blade technology and chisel-shaped or oblique points/flake technology; others sub-divide the period into three phases: early, middle and late Neolithic - mainly pottery-based. In the present paper the former distinction will be made.) One point is a small teardrop-shaped piece which cannot be dated more precisely than to the period in general, whereas the other piece (CAT 2296 ) is somewhat angular and belongs to the group of 'kite-shaped' arrowheads. These points are usually associated with the later part of the early Neolithic (in northern England, the Towthorpe Burial Tradition, Green 1980, 85; or Early Individual Burials, Clarke et al 1985, 63-7), and with artefacts, such as Seamer/Duggleby axes and polished flint knives. The Scord of Brouster assemblage also includes a number of fragments of leaf-shaped points or rough-outs for such points.

The curved knives may be dated by their invasive retouch to the Neolithic/Early Bronze Age period sensu largo, and the fact that some of these pieces were recovered from the same contexts as the leaf-shaped points (pre-wall contexts in House 1) suggests an early Neolithic date. The curved flint knife from Camster Long (Davidson \& Henshall 1991, 101, fig 21; Wickham-Jones 1997, 162, fig 22) forms part of a larger lithic assemblage, including Mesolithic as well as early Neolithic elements. Though it is not possible to determine which of the Camster Long artefacts are contemporary, it is encouraging that this assemblage combines curved knives and kite-shaped arrowheads, like the Scord of Brouster assemblage (for discussion of the radiocarbon dates from Camster Long, see below).

Knives with cutting-edges formed by invasive retouch (CAT 2243) are defined by their invasive retouch as either Neolithic or Early Bronze Age implements, and denticulated pieces (CAT 2090, 2258) have been associated with later prehistoric environments (for example, Saville 1981; Herne 1991). The use of felsite in the production of polished Shetland knives or polished stone axeheads has traditionally been dated to the late Neolithic or the Early Bronze Age (Fojut 1986, 17-18; Saville 1994, 60-1), but during an inspection in 2004 of felsite artefacts in the collections of the Shetland Museum, the author noticed several small kite-shaped arrowheads in this material (for example, ARC 662 and ARC 666, labelled 'Lerwick' and 'Semblester, Sandsting', respectively), suggesting a slightly earlier date for the commencement of Shetland felsite quarrying and use.

The blanks, cores and tools from Scord of Brouster were generally relatively small, with sizes corresponding to those of artefacts from Mesolithic quartz assemblages, and differing from sizes of artefacts from later prehistoric quartz assemblages (Table 5). This fact supports the suggested Neolithic date of the Scord of Brouster material, although it must be borne in mind that the chosen assemblages represent different geological regions (Shetland, western mainland Scotland and the Western Isles), and the size of the available raw material may be partly responsible for the observed size differences.

A series of radiocarbon dates (14) was obtained from the site (Whittle 1986, table 1), forming a sequence from House 2 (early), through House 1 to House 3 (late) (Illus 34; for a discussion of the stratigraphy and phasing of the three houses, see Whittle 1986, 12-38). All the following dates were calibrated by the author using the program OxCal v3.8 (95.4\% probability). The earliest date from House 2 is from its late Phase 2 (CAR-253: 3990-3650 cal BC) and should probably be disregarded; the remaining dates (CAR-249: 3370-2920 cal BC; CAR-250: 3350-2920 cal BC; CAR 251: 3500-3439 and 3380-3020 cal BC; CAR-252: 3340-2880 cal BC), mainly from Phase 1, form a dense cluster in the period 3500-2900 cal BC. In House 1, two Phase 1 dates (CAR-244: 3350-2920 cal BC; CAR-245: 3350-2700 cal BC) overlap with, and form a continuation of, the latest dates from House 2 , with four of the remaining five dates clustering around 2900-2500 cal BC (CAR-243: 2880-2470 cal BC; CAR-246: 2890-2490 cal BC; CAR-247: 2890-2490 cal BC; HAR-2413: 2920-2490 cal BC); the last date from House 1 is a late 'outsider' (CAR-248: 2300 
Table 5 Comparison between the average dimensions of the most common quartz types from Mesolithic, Neolithic, Early Bronze Age and Later Bronze Age assemblages

\begin{tabular}{lcccc}
\hline & $\begin{array}{c}\text { Mesolithic (Lussa } \\
\text { River) }(\mathbf{m m})\end{array}$ & $\begin{array}{c}\text { Neolithic (Scord of } \\
\text { Brouster) } \mathbf{( m m})\end{array}$ & $\begin{array}{c}\text { Early Bronze Age } \\
\text { (Rosinish) }(\mathbf{m m})\end{array}$ & $\begin{array}{c}\text { Later Bronze Age } \\
\text { (Bayanne) }(\mathbf{m m})\end{array}$ \\
\hline Single-platform cores & $38 \times 33 \times 26$ & $27 \times 29 \times 34$ & $44 \times 40 \times 34$ & $40 \times 44 \times 37$ \\
Bipolar cores & $27 \times 19 \times 11$ & $27 \times 20 \times 12$ & $36 \times 27 \times 18$ & $44 \times 34 \times 23$ \\
Short end-scrapers & $30 \times 24 \times 12$ & $30 \times 22 \times 12$ & $45 \times 36 \times 20$ & $37 \times 31 \times 19$ \\
\hline
\end{tabular}

1750 cal BC) from Phase $2 b$. Both dates from House 3 are from its Phase 1, suggesting a date for this structure of $c$ 1500-1900 cal BC (CAR-477: 17401440 cal BC; CAR-479: 1890-1520 cal BC). If these dates represent the main occupation of the houses, this defines the Houses 1, 2 and 3, as mainly late Neolithic, early Neolithic and Early Bronze Age, respectively.

Four radiocarbon dates (Davidson \& Henshall 1991, 102) have been obtained from Camster Long, namely one from activities in front of the platform in the south forecourt (4000-3050 cal BC), and three from buried soil under the southern part of the cairn (GU-1707: 3960-3630 cal BC; GU-1708: 3940-3870, 3810-3630 and 3560-3530 cal BC; GU-1709: 4000$3350 \mathrm{cal} \mathrm{BC}$ ). Due to the find circumstances, it is not possible to relate any of these radiocarbon dates securely with any parts of the lithic assemblage, but the date from activities in the south forecourt (4000-3050 cal BC) represents a terminus ante quem for the curved knife and the kite-shaped points found in the pre-cairn soil (Davidson \& Henshall 1991, 101-2). The remaining three radiocarbon dates may date these implements. If this is accepted, the dates from Camster Long and Scord of Brouster suggest a northern British, or Scottish, horizon including kite-shaped points and curved knives encompassing the period $c 4000-3000 \mathrm{cal}$ BC. The tradition of Early Individual Burials, referred to above, has been dated (in calendar years) to the end of the fourth millennium BC (Clarke et al 1985, 14, 63-7, 246-51).

With most ( $c 90 \%$ ) of the House 2 sub-assemblage deriving from later phases (Phase 2 construction, Phase 2 and Phase 3), and most (c 68\%) of the House 1 sub-assemblage being from the early Phase 1 , it is possible that the major part of the quartz assemblage forms a chronological whole, dating to the very end of the early Neolithic period (associated with, inter alia, kite-shaped points and curved knives). This is supported by the fact that the bifacial curved points, presently unique to the assemblages from Scord of Brouster, Camster Long and Druim Arstail, were recovered from early and late House 2 contexts (seven pieces), but only early House 1 contexts (five pieces). The sub-assemblage from House 3 is small (227 pieces or $c 2 \%$ of the entire assemblage) and uncharacteristic; it only includes one tool and one core, both undiagnostic, and most of the material is undatable outer vein rubbish from the decortication of quarried quartz plates and nodules.

\subsection{The quartz assemblage from Scord of Brouster compared with other Neolithic assemblages from Scotland - the regional context}

In the present chapter the assemblage from Scord of Brouster is compared with other Neolithic quartz and non-quartz assemblages from Scotland, but only finds from settlements are included in the comparison. Due to an uneven distribution of Neolithic sites across the country, a region-by-region comparison is not feasible and, instead, the author has chosen to focus on the most important elements of variation: assemblage size, raw materials, artefact size, typology and technology (see Table 6 for an overview). The analysis is influenced by the fact that many Neolithic assemblages from Scotland remain unpublished.

\subsubsection{Assemblage size}

Most chronologically 'clean' lithic assemblages from Scottish Neolithic sites are small, usually numbering from a handful of pieces (for example, Dunloskin, Argyll, Rennie 1977, 6; Wardend of Durris, Russel-White 1995) to a few hundred pieces (for example, Beckton Farm, Dumfries and Galloway, Pollard 1997; Auchategan, Argyll, Marshall 1978). Larger assemblages do, however, exist and, in terms of size, the Scord of Brouster assemblage is not unique. Substantial collections are known from several Orcadian sites, with the assemblage from Tofts Ness (Dockrill 1987) being the largest (7280 pieces), but sizeable collections have also been recovered from sites in the Western Isles (Eilean Dhomnuil - 'hundreds of pieces'; Finlayson, forthcoming; A Saville pers comm), and sites in the Highland (Lairg - c 10,000 pieces; Finlayson 1996) and in Argyll (Carding Mill Bay - 990 pieces; Connock et al 1992). A number of large mixed assemblages from the Scottish west coast and the Southern Hebrides contain Neolithic elements (for example, Shieldaig; Ballin et al, forthcoming; Lussa River, Ballin 2002; Ellary Boulder Cave, Tolan-Smith 2001), but in none of these cases is it possible to assess the precise proportion of the Neolithic component.

The distribution of large and small Neolithic assemblages across Scotland is not unequivocal, partly because of the uneven distribution of 


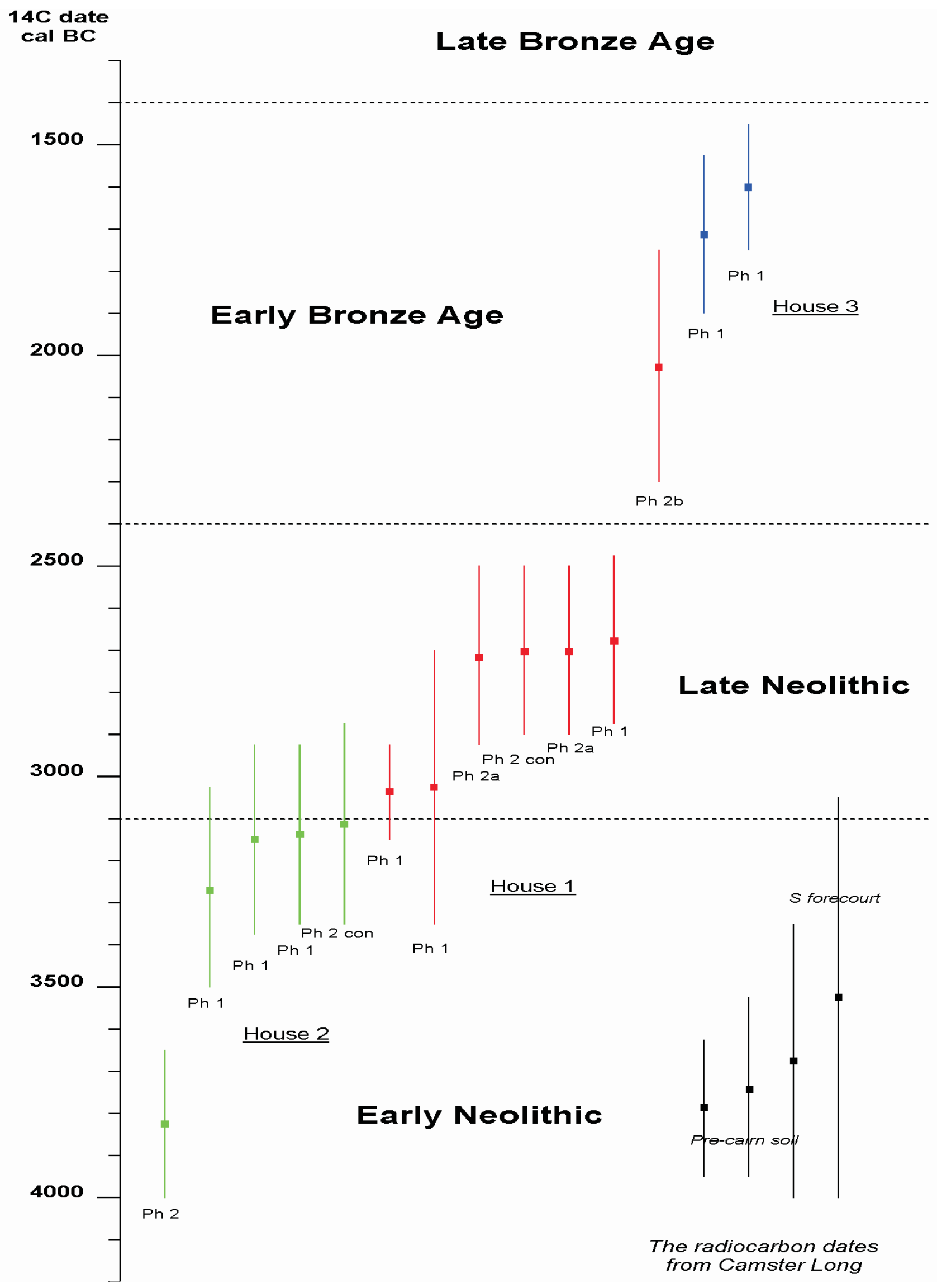

Illus 34 Radiocarbon dates; the dates were calibrated by the author using OxCal v3.8 (95.4\% probability). For comparison, the dates from Camster Long have been inserted in the lower right corner 
Table 6 The general characteristics of Neolithic assemblages from the two main raw material provinces of Scotland. The province of the west coast of the Scottish mainland/Southern Hebrides constitutes a hybrid form of these two

\begin{tabular}{lll}
\hline & $\begin{array}{l}\text { The quartz province of northern and } \\
\text { western Scotland }\end{array}$ & $\begin{array}{l}\text { The flint (and similar raw materials) } \\
\text { province of eastern, central and southern } \\
\text { Scotland }\end{array}$ \\
\hline Assemblage size & $\begin{array}{l}\text { Several very large assemblages: Scord of } \\
\text { Brouster 9687, Lairg c 10,000 }\end{array}$ & $\begin{array}{l}\text { Mostly smaller assemblages, from a handful of } \\
\text { pieces to a few hundred pieces }\end{array}$ \\
Artefact size & $\begin{array}{l}\text { The general artefact size is comparable to that } \\
\text { of the Mesolithic period (relatively small) }\end{array}$ & $\begin{array}{l}\text { Varying artefact sizes: some assemblages } \\
\text { consist of mainly larger pieces (Lunanhead), } \\
\text { some of mainly smaller pieces (Auchategan) }\end{array}$ \\
& $\begin{array}{l}\text { Flake production, either by the application of } \\
\text { Technology }\end{array}$ & $\begin{array}{l}\text { Blade (EN) or flake (LN) production, the former } \\
\text { mainly by the application of soft percussion, the }\end{array}$ \\
& & $\begin{array}{l}\text { latter by hard percussion and/or bipolar } \\
\text { technique }\end{array}$ \\
Typology & $\begin{array}{l}\text { Limited tool selection: dominance of scrapers, no } \\
\text { or few arrowheads, some retouched pieces and } \\
\text { individual specimens of other tool types - no } \\
\text { serrated pieces }\end{array}$ & $\begin{array}{l}\text { More varied tool selection: less marked } \\
\text { dominance of scrapers, more arrowheads, } \\
\text { serrated pieces, truncated pieces, plano-convex } \\
\text { knives and other tool types }\end{array}$ \\
\hline
\end{tabular}

Neolithic finds in general, but large assemblages do appear to be concentrated mainly in the western and northern parts of the country, with assemblages from eastern, central and southern Scotland generally being smaller. It is quite possible that this situation is, in part, artificial and reflects the fact that the eastern, central and southern parts of Scotland have been more densely populated throughout prehistory and history, and that agricultural and industrial activities have, to some degree, destroyed many prehistoric settlements and monuments (see, for example, the distribution of chambered tombs in central Scotland; Henshall 1972). However, the sizeable Neolithic component in some surface collections (for example, Robert Fortune's collection from Airhouse, Berwickshire; Callander 1928) suggests that larger Neolithic settlement assemblages may yet be uncovered, if not in the heavily built-up Central Belt then possibly in eastern and southern Scotland.

However, Warren's analysis of the early Neolithic industries of eastern Scotland shows that the assemblages from this region generally have smaller proportions of débitage and higher tool ratios (Warren, forthcoming). It is possible that the small assemblage sizes of the Scottish east and south reflect, at least partly, differences in the spatial organization of lithic knapping (separation of knapping floors and living spaces?), differences in site maintenance (more vigorous clearing of settlement surfaces in eastern/southern Scotland?), or the site types excavated in eastern and southern Scotland differ from site types excavated elsewhere (as an example, Warren emphasizes the presence of large middens on Orcadian sites). The different flaking properties of quartz and other lithic raw materials definitely played a role in the regional variation of assemblage sizes, as the tendency of many quartz varieties to disintegrate uncontrolledly generally creates more débitage per finished tool.

\subsubsection{Raw materials}

Throughout prehistory, Scotland appears to be divided into a number of raw material zones. Many of these are small, like the Arran pitchstone zone, the Rùm bloodstone zone and the Orcadian/Caithness flint zone (the latter sandwiched between quartzusing areas), but on a more general level Scotland may be divided into only three main raw material provinces: the quartz-dominated north and west of the country; eastern, central and southern Scotland, where flint and similar lithic raw materials (chert, chalcedony, pitchstone, and so on) were exploited; and west-coast mainland Scotland/the Southern Hebrides, constituting a hybrid form based on the use of quartz and relatively large supplements of flint and raw materials with similar flaking properties (Rùm bloodstone, Staffin baked mudstone and so on) or, in some cases, the exclusive use of flint (for example, Newton, Islay; Clarke 1989).

Scord of Brouster is characterized by an almost total dominance of quartz, with flint only constituting $c 1 / 1000$, whereas the assemblage from Sumburgh on the southern tip of Shetland (Finlayson 2000) includes $1 \%$ flint. The late Neolithic/Bronze Age assemblage from Lairg, Sutherland (Finlayson 1996), has a similar raw material composition with $c$ 99\% quartz and c 1\% flint. Neolithic and Bronze Age collections from the Western Isles generally have a high quartz ratio, with flint and mylonite forming significant sub-assemblages; the raw material composition of the late Neolithic/Early Bronze Age assemblage from Calanais (Ballin, in prep a) is quartz $74 \%$, flint $14 \%$ and mylonite $12 \%$.

As many assemblages from the Scottish west coast and the Southern Hebrides are chronologically mixed, it is difficult to calculate reliable raw material ratios for the Neolithic of this region; some are heavily dominated by quartz (Carding Mill Bay; Connock et al 1992), whereas others are heavily 


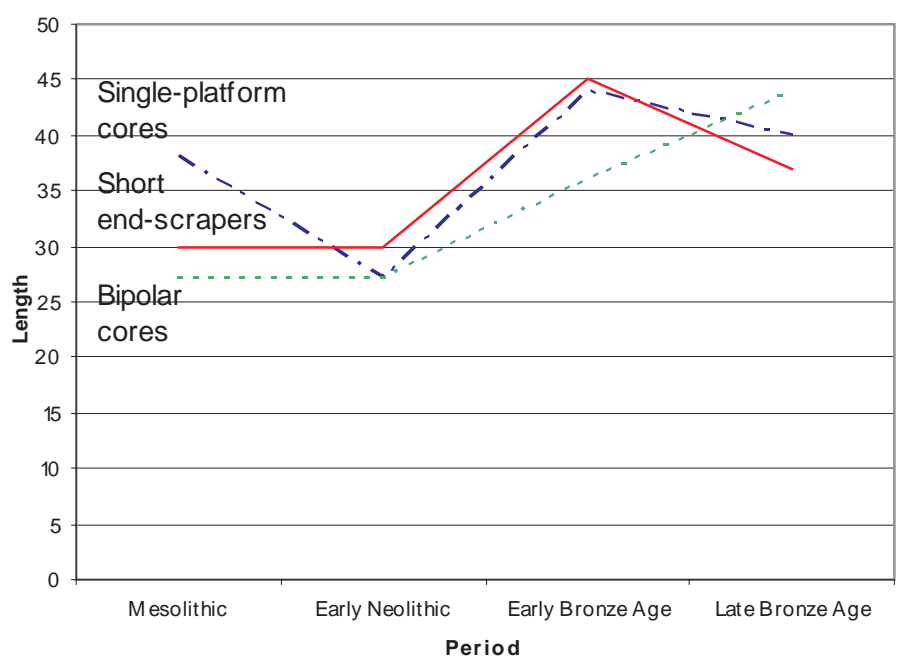

Illus 35 The lengths of single-platform cores, short end-scrapers and bipolar cores from representative Mesolithic, Neolithic and Bronze Age assemblages (see Table 5)

dominated by flint (Newton, Area 1 Upper Terrace, Islay; Clarke 1989) and some flint- or quartzdominated assemblages are supplemented by noticeable proportions of locally available raw materials, such as bloodstone or baked mudstone, or imported exotica like pitchstone (for example, Ellary Boulder Cave, Argyll - 75 pieces of pitchstone; Tolan-Smith 2001).

Neolithic sites from eastern and central Scotland (as well as the Orcadian and Caithness 'enclaves') are usually heavily dominated by flint, or their assemblages are exclusively in flint (for example, Aberdeen City, Ballin, forthcoming a; Lunanhead, Angus, Wickham-Jones \& MacKenzie 1996; Balbridie, Kincardineshire, Sabine \& Warren 2002). In Orkney there is some use of local chert, for example, at Skara Brae (Childe 1931, 113), and throughout eastern Scotland flint was supplemented by some quartz or agate (for example, at Hawkhill, Angus Warren no date - if a cache of unworked agate pebbles is disregarded, the ratios of this assemblage are flint $45 \%$, agate $34 \%$ and quartz $21 \%$ ). Neolithic collections from southern Scotland generally include large proportions of flint and Southern Uplands chert, with some assemblages being dominated by the former (Beckton Farm, Dumfries and Galloway; Pollard 1997) and some by the latter (Tinto Sand and Gravel Pit, South Lanarkshire; Ballin 2003).

Outside Arran (Williams Thorpe \& Thorpe 1984), identified as the likely source of most, if not all, archaeological pitchstone, pitchstone forms part of an impressively large number of Neolithic collections, from the Scottish Borders to Orkney (Ness \& Ward 2001), but so far no pitchstone has been recovered from any Shetland sites. Large assemblages of pitchstone artefacts have almost exclusively been recovered from southern Scotland and from the southern part of Argyll.

The use of specific raw materials in lithic production generally reflects either function (availability) or style (". . . formal variation in material culture that transmits information about personal and social identity'; Wiessner 1983, 256; for a general discussion of the concept of style, see Ballin, forthcoming d). Raw material preference as an expression of function usually results in a gradually declining fall-off curve (Renfrew 1977, 73) with growing distance to the outcrop, whereas raw material preference as an expression of style is characterized by a marked drop in frequency at the borders of the social territory in question (Hodder 1979, 447). Stylistic use of a raw material is demonstrated by the almost exclusive use of rhyolite in early Neolithic south-west Norway, with the raw material deriving from one central locality (the Bømlo Quarry; Alsaker 1987), and with a marked drop in the rhyolite frequency at the borders of that territory (Ballin, forthcoming d). A similarly exclusive distribution pattern has not been demonstrated in connection with the raw materials recovered from Scottish Neolithic sites, with most assemblages displaying a combination of raw materials generally reflecting local availability.

How pitchstone was used on Arran, and perceived as an either utilitarian or non-utilitarian resource, is still uncertain, as very little lithic material has been published from the island (in 1999, a number of Mesolithic and Neolithic sites were excavated on Arran in connection with the construction of a pipeline; Donnelly 1999), but the distribution of pitchstone across Scotland suggests that some nonutilitarian value was attached to this raw material. Pitchstone knapping debris has been recovered from sites in southern Scotland and southern Argyll (Ness \& Ward 2001; Tolan-Smith 2001), but on most sites outside this region pitchstone appears as individual, or at most a handful, of pieces. Warren points out that these specimens are usually high quality pieces of unmodified débitage (Warren, forthcoming), and they were probably not intended for practical use; a small pitchstone nodule from the site of Achnahaird Sands, Highland (Ballin, forthcoming b), does not fit this picture. 


\subsubsection{General artefact size}

As demonstrated by Table 5 and Illus 35, the general artefact size varies between assemblages within the Scottish quartz province, with artefacts from Neolithic Scord of Brouster being of roughly the same small proportions as artefacts from Mesolithic assemblages, but somewhat smaller than artefacts from Early and Late Bronze Age assemblages. However, as the following comparison demonstrates, general dimensions also differ between contemporary Neolithic settlement collections.

The somewhat unusual group of mainly blanks from Lunanhead, Angus, is assumed on technological grounds to be early Neolithic (Wickham-Jones \& MacKenzie 1996, 13). The pieces, many of which were fragmented, had an average length of $c 45 \mathrm{~mm}$, with several blades being almost 70mm long. Almost as large blades were found in connection with the excavation of Trench $\mathrm{H}$ at the Carmelite Friary in Aberdeen (Ballin, forthcoming a). Outside eastern Scotland, lithic artefacts are usually a fraction smaller, with chert (for example, Tinto Sand and Gravel Pit, South Lanarkshire; Ballin 2003) and pitchstone (for example, Auchategan; Marshall 1978) blanks having dimensions comparable to those of the quartz artefacts from Scord of Brouster.

As mentioned above, there is no logical explanation to the generally small size of the Scord of Brouster quartz artefacts, but the size of the artefacts from various non-quartz assemblages in eastern, central and southern Scotland appears mainly to be linked to local raw material availability, the size of local pebbles and nodules and the flaking properties of these materials. Eastern Scotland is comparatively rich in flint which can be found in beach deposits or inland gravel deposits, and these nodules are frequently fairly large - though too a large extent of fairly poor quality (Saville 1994; Saville 1995; A Saville, pers comm). Chert, chalcedony and agate do occasionally appear as large nodules, but in most cases these raw materials are found in the form of relatively small pebbles. Though pitchstone does form substantial dykes and sills (Williams Thorpe \& Thorpe 1984, 2), no quarry sites have been found, examined and published (though a knapping floor was detected near the Brodick Schoolhouse outcrop; Mann 1918, 144), and it is not known to which extent the collection of pitchstone beach pebbles or erratics played a role.

\subsubsection{Technology}

The radiocarbon determinations from Scord of Brouster date this assemblage (Houses 1 and 2) to the transition between the early and late Neolithic periods. In general, the British early Neolithic is defined by the presence of leaf-shaped arrowheads and regular, parallel-sided macroblades (Edmonds 1995), whereas the British late Neolithic is characterized by the presence of chisel-shaped or oblique arrowheads and elongated flake blanks (Manby 1974). In typo-technological terms, the Scord of Brouster assemblage is a hybrid form defined by leaf-shaped points and the production of elongated flakes, and regular macroblades were not manufactured at this location.

Technologically, the Neolithic assemblages of Scotland can be subdivided into three groups in the same way as they were sorted in connection with the analysis of raw material use in the Scottish Neolithic (above): the Scottish quartz province is characterized by the production of elongated flakes through the early and late Neolithic periods (for example, Scord of Brouster, Shetland, this paper; and Lairg, Sutherland, Finlayson 1996); in the eastern, central and southern parts of Scotland flint, chert or similar raw materials were in use, and the industries are characterized by the manufacture of regular broad blades in the early Neolithic (for example, the Carmelite Friary, Aberdeen; Ballin, forthcoming a) and a flake technology in the late Neolithic (for example, Beckton Farm, Dumfries and Galloway; Pollard 1997); and the zone of the Southern Hebrides/western mainland Scotland is defined by opportunistic raw material use and an equally opportunistic choice of technological approach. Early Neolithic assemblages dominated by quartz represent flake industries (for example, Carding Mill Bay, Argyll; Connock et al 1992) and contemporary flint-dominated assemblages represent blade industries (for example, Newton, Islay; Clarke 1989), with the situation being less clear in the late Neolithic period due to fewer finds. Some assemblages, like Auchategan, Argyll (Marshall 1978), display more than one technological approach, with the pitchstone artefacts representing a blade technology and the quartz artefacts a flake technology.

The choice of percussion technique varies between soft percussion, hard percussion and bipolar technique. Bipolar technique is either the main approach to detaching blanks or it may be the final stage of a complex operational schema, primarily employed to completely exhaust abandoned platform cores. In Neolithic Scotland, quartz blanks may be detached in various ways, with the assemblage from Scord of Brouster representing a hard-hammer approach (supported by bipolar technique), and the lithic finds from Carding Mill Bay (Connock et al 1992) representing an entirely bipolar approach. Collections of artefacts in flint and related materials were mostly produced by the application of platform techniques, with the early Neolithic assemblages mainly representing soft-hammer percussion on single-platform cores (for example, the pitchstone sub-assemblage from Auchategan; Marshall 1978), whereas late Neolithic assemblages represent more robust techniques on simpler, usually irregular, core forms (for example, Beckton Farm, Dumfries and Galloway; Pollard 1997). Flint and similar collections in most cases include some bipolar cores as well.

The technological choices of the Scottish Neolithic 
appear to be basically opportunistic, reflecting mainly raw material availability and the flaking properties of the available lithic materials. The choice, for example, of whether to apply hard percussion or bipolar technique in the reduction of quartz may mainly be a matter of size - the larger, quarried nodules at Scord of Brouster allowed hard percussion to be used, whereas the smaller beach pebbles at Carding Mill Bay made bipolar reduction more appropriate (cf Ballin 1999a).

\subsubsection{Typology}

The typological composition of the Neolithic assemblages of Scotland shows the same dichotomy as described in connection with the discussion of the technology of these industries: the quartz assemblages generally display a limited selection of morphological types, whereas the assemblages in flint and flint-like materials frequently display the full range of tool types, with a general assemblage composition similar to that of Neolithic assemblages of southern Britain (Edmonds 1995).

The quartz assemblages are usually characterized by a marked dominance of scrapers (in the case of Scord of Brouster, 75\% of the tools), supplemented by a small number of arrowheads (if any), some retouched pieces and individual specimens of other tool types. Uniquely, the assemblage from Scord of Brouster also includes 12 curved knives a type only known from two other Scottish sites (Camster Long, Caithness, Wickham-Jones 1997; and Druim Arstail, Oronsay, Wickham-Jones et al 1982). Presently, this tool type seems to be limited to the later part of the early Neolithic period of north-west Scotland, and they were made in flint as well as in quartz. Assemblages in flint and flint-like raw materials in most cases include a slightly smaller proportion of scrapers, though scrapers usually dominate the tools, supplemented by arrowheads, serrated pieces, truncated pieces, and - occasionally - plano-convex knives (cf table in Warren, forthcoming). At present, it would be statistically unsound to put forward exact proportions of the various tool types, as the majority of the known Neolithic assemblages from eastern, central and southern Scotland are fairly small (see above).

The different typological compositions of Neolithic assemblages from eastern/central/southern Scotland and northern/western Scotland may be due to a number of factors, but most likely differences in raw material availability and subsistence economy are the more important ones. Flint and quartz, for example, have different flaking properties - a fact probably best demonstrated by the geologically mixed assemblages from western Scotland: if flint and quartz were being exploited simultaneously on a site, artefact types requiring neat pressure flaking or invasive retouch are mostly in flint (for example, the various chronologically mixed Jura sites; Mercer 1968; Mercer 1971; Mercer 1972).

As little, or no, organic material has been preserved from most Neolithic sites of Scotland it is difficult to positively demonstrate differences between the economies of the various sites, but with most locations from the north and west being situated either on islands or directly on the west mainland coast, and many locations from the south and east being inland sites, it is obvious that economic differences must have existed between these two groups of sites. It is logical to associate a 'semi-diagnostic' type such as the serrated piece with inland sites, as detailed use-wear analysis has demonstrated that this type may mainly have been used for the processing of plant material (Juel Jensen 1988; Juel Jensen 1994). 


\section{Conclusion and Future Perspectives}

As demonstrated above, the lithic assemblage from Scord of Brouster adds valuable elements to the discussion of regionality in the Scottish Neolithic period. By comparing this Neolithic Shetland collection with contemporary material from other regions of Scotland, it has been possible to define two distinctly different raw material provinces, as well as a third, hybrid form. The quartz province, to the north and west, and the flint/chert province, covering the eastern, central and southern parts of the country, have been characterized as techno-complexes:

A techno-complex is composed of a number of social territories between which there is usually a low degree of social interaction. The social territories forming part of a techno-complex share essential functional artefact types and, first of all, technological elements based on a common general subsistence strategy, usually geographically delimited to an area with a uniform topography and ecology (Ballin, forthcoming d).

It is uncertain which status to attach to the mixed quartz/flint province of the west mainland and the Southern Hebrides. Most likely, more research into the material culture of the main techno-complexes will allow further subdivision of these territorial units, but this requires an increase in the available lithic finds (for example, in eastern and southern Scotland), the addition of larger, more representative assemblages. The present 'State of the Art' is summed up in Table 6, specifying the main typological, technological and size differences between the complexes.

As implied by the definition of a techno-complex, the above subdivision of Neolithic Scotland is based mainly on topographical, ecological and subsistence-economic differences, and only to a minor degree social differences, or ethnicity. To investigate the social division (the social territories) of Neolithic Scotland, it would be necessary to compare chronologically 'clean', representative, contemporary assemblages within one techno-complex, focusing on the possible presence of stylistically different artefact types, as opposed to the functionally different types characterizing techno-complexes.

Similarities and differences between the Neolithic assemblage from Scord of Brouster and Scottish Mesolithic and Bronze Age quartz assemblages were only touched upon briefly in this paper (for example, Table 5 and Illus 35), but a detailed discussion of temporal variation within the Scottish quartz province is planned to form part of the concluding paper from the project Quartz Technology in Scottish Prehistory. 


\section{Acknowledgements}

The author is grateful to Historic Scotland for being the main grant-aider of this project, and to the Society of Antiquaries of Scotland for covering the project's expenses. Thanks are also due to Shetland Museum for much needed practical aid relating to the loan of the Scord of Brouster quartz assemblage, and to Principal Monuments Inspector Patrick Ashmore at Historic Scotland for his interest and support, as well as relevant comments to the manuscript. Mr Tommy Watt at Shetland Museum is thanked for his co-operation and patience, and Senior Curator Alan Saville, the National Museums of Scotland, for his detailed comments to the manuscript. I am grateful to Archaeological Project Manager Beverley Ballin Smith from Glasgow University Archaeological Research Division, for photographing the most important artefacts and commenting on consecutive manuscript versions; to Dr Alan Hall from the Department of Archaeology, University of Glasgow, for defining the raw material of several 'difficult' rock types; to Professor Alasdair Whittle, Cardiff University, for permission to use the location map from his original Scord of Brouster publication; and to Frances Healy, Cardiff University, for advice on the radiocarbon chronology of the British Neolithic and Bronze Age periods. 


\section{References}

Alsaker, S 1987 Bømlo - Steinalderens råstoffsentrum på Sørvestlandet. Arkeologiske Avhandlinger 4. Historisk Museum, Universitetet i Bergen, Bergen.

Andersen, S H 1972 Bro. En senglacial boplads på Fyn. Kuml 1972, 7-60.

Ashton, N, Dean, P, \& McNabb, J 1991 Flaked flakes: what, when and why? Lithics 12, 1-11.

Ballin, T B 1996 Klassifikationssystem for Stenartefakter. Universitetets Oldsaksamling, Varia, 36, Oslo.

Ballin, T B 1999a Bipolar cores in southern Norway: classification, chronology and geography. Lithics 20, 13-22.

Ballin, T B 1999b Kronologiske og Regionale Forhold $i$ Sydnorsk Stenalder. En analyse med udgangspunkt $i$ bopladserne ved Lundevågen (Farsundprosjektet). Unpublished $\mathrm{PhD}$ dissertation. Institute of Prehistoric Archaeology, Aarhus University, Aarhus.

Ballin, T B 2000 Classification and description of lithic artefacts. A discussion of the basic lithic terminology. Lithics 21, 9-15.

Ballin, T B 2002 The Quartz Assemblage from Lussa River, Isle of Jura. Unpublished report.

Ballin, T B 2003 The Lithic Assemblage from Tinto Sand and Gravel Pit, Thankerton, South Lanarkshire. Unpublished report.

Ballin, T B 2004 'The worked quartz vein at Cnoc Dubh, Isle of Lewis, Western Isles. Presentation and discussion of a small prehistoric quarry', Scottish Archaeological Internet Reports (SAIR) 11 (http:// www.sair.org.uk/sair11/index.html).

Ballin, T B forthcoming a 'The lithic assemblage', in Cameron, A (ed) Excavations at the Green, Aberdeen: a medieval Carmelite House revealed. Internet Archaeology.

Ballin, T B forthcoming $b$ 'The lithic assemblage', in Cox, A (ed) Achnahaird Sands, Highland. Society of Antiquaries of Scotland Monograph, Edinburgh.

Ballin, T B forthcoming c 'The quartz assemblage', in Moore, $\mathrm{H}$, \& Wilson, $\mathrm{G}$ (eds) The Bayanne Project, Shetland. Shetland Amenity Trust Monograph, Lerwick.

Ballin, T B forthcoming d 'The territorial structure in the Stone Age of Southern Norway', in Pedersen, K, \& Waddington, C (eds) The Late Palaeolithic and Mesolithic of the North Sea Basin and Littoral, Proceedings from a Conference at the University of

Newcastle-upon-Tyne, 17 May 2003. Oxbow Books, Oxford.

Ballin, T B in prep a 'The lithic assemblage', in
Ashmore, P (ed) Calanais, Lewis, Western Isles. Proc Soc Antiq Scot.

Ballin, T B in prep b 'The lithic assemblage', in Sharples, N (ed) Dalmore, Lewis, Western Isles.

Ballin, T B in prep c 'The lithic assemblage', in Shepherd, I \& Shepherd, A (ed) Rosinish, Benbecula, Western Isles. Proc Soc Antiq Scot.

Ballin, T B in prep d 'Recognition of burnt quartz and its relevance to the interpretation of prehistoric sites', Lithics.

Ballin, T B, \& Lass Jensen, O 1995 Farsundprosjektet - Stenalderbopladser på Lista. Universitetets Oldsaksamling, Varia, 29. Universitetets Oldsaksamling, Oslo.

Ballin, T B, Saville, A, \& Walker, M forthcoming The Lithic Assemblage from Shieldaig, Wester Ross.

Binford, L R 1983 In Pursuit of the Past. Decoding the Archaeological Record. Thames \& Hudson, London.

Broadbent, N 1979 Coastal Resources and Settlement Stability. A Critical Study of a Mesolithic Site Complex in Northern Sweden. Aun, 3. Archaeological Studies, Uppsala University Institute of North European Archaeology, Uppsala.

Broadbent, N, \& Knutsson, K 1975 'An experimental analysis of quartz scrapers, results and applications', Fornvännen, 3/4, 113-28.

Calder, C S T 1956 'Report on the discovery of numerous Stone Age house-sites in Shetland', Proc Soc Antiq Scot 89, 340-97.

Calder, C S T 1964 'Cairns, Neolithic houses and burnt mounds in Shetland', Proc Soc Antiq Scot 96 (1963-4), 37-86.

Callander, J G 1928 'A collection of stone implements from Airhouse, Parish of Channelkirk, Berwickshire', Proc Soc Antiq Scot LXII, 166-80.

Childe, V G 1931 Skara Brae. A Pictish Village in Orkney. Kegan Paul, Trench, Trubner, London.

Clarke, A 1989 'The flaked lithics', in McCullagh, R $\mathrm{J}$ (ed) Excavation at Newton, Islay, 32-6. Glasgow Archaeol J 15 (1988-9), 23-51.

Clarke, D V, Cowie, T G, \& Foxon, A 1985 Symbols of Power at the Time of Stonehenge. National Museum of Antiquities of Scotland, Edinburgh.

Connock, K D, Finlayson, B, \& Mills, A C M 1992 'The excavation of a shell midden site at Carding Mill Bay, near Oban, Scotland', Glasgow Archaeol J (1991-2) 17, 25-38.

Crabtree, D E, \& Gould, R A 1970 'Man's oldest craft re-created', Curator XIII/3, 179-98.

Davidson, J L, \& Henshall, A 1991 The Chambered 
Cairns of Caithness. Edinburgh University

Press, Edinburgh.

Dixon, T N, \& Cavers, M G 2001 'Oakbank Crannog, Loch Tay (Kenmore parish): excavation', Discovery Excav Scot 2, 78-9.

Dockrill, S J 1987 Excavations at Tofts Ness, Sanday. Interim 1987. Unpublished report. School of Archaeological Sciences, University of Bradford, Bradford.

Donnelly M 1999 Arran Ring Main Water Pipe Line. GUARD Data Structure Report 731. Unpublished Report.

Edmonds, M 1995 Stone Tools and Society. Batsford, London.

Eriksen, B V 1999 'Varmebehandling af flint - et eksperimental-arkæologisk studie', in Høiris, O, Madsen, H J, Madsen, T, \& Vellev, J (eds) Menneskelivets mangfoldighed. Arkæologisk og antropologisk forskning på Moesgård, 185-92. Aarhus Universitet \& Moesgård Museum, Højbjerg.

Eriksen, B V 2000 'Chaîne opératoire' - den operative proces og kunsten at tænke som en flinthugger', in Eriksen, B V (ed) Flintstudier en håndbog $i$ systematiske analyser af flintinventarer, 101-26. Aarhus University Press, Aarhus.

Finlayson, B 1996 'Worked flint and quartz', in McCullogh, R P J \& Tipping, R (eds) The Lairg Project 1988-96. The Evolution of an Archaeological Landscape in Northern Scotland. AOC Monograph 3, 132-9, Edinburgh.

Finlayson, B 2000 'Chipped stone assemblage', in Downes, J \& Lamb, R (ed) Prehistoric Houses at Sumburgh in Shetland. Excavations at Sumburgh Airport 1967-74. Oxbow Books, Oxford.

Finlayson, B forthcoming 'The flint and quartz artefacts', in Armit, I (ed) forthcoming Excavations at the Neolithic site of Eilean Domhnuill, Loch Olabhat, North Uist.

Fischer, A, Grønnow, B, Jønsson, J H, Nielsen, F O, \& Petersen, C 1979 Stenaldereksperimenter i Lejre. Bopladsernes indretning. Working Papers, The National Museum of Denmark 8. The National Museum of Denmark, København.

Flennikin, J J 1981 Replicative Systems Analysis: A Model Applied to the Vein Quartz Artifacts from the Hoko River Site. Washington State University, Laboratory of Anthropology Reports 59. Washington State University, Ann Arbor.

Fojut, N 1986 A Guide to Prehistoric \& Viking Shetland. Shetland Times, Lerwick.

Green H S 1980 The Flint Arrowheads of the British Isles. A detailed study of material from England and Wales with comparanda from Scotland and Ireland. Part i-ii. Oxford (=Br Archaeol Rep, Br Ser 75).

Healy, F 1996 The Fenland Project, Number 11:
The Wissey Embayment: Evidence for Pre-Iron Age Occupation Accumulated Prior to the Fenland Project. East Anglian Archaeology, Report 78, Gressenhall.

Henshall, A S 1972 The Chambered Tombs of Scotland, Vol 2. Edinburgh University Press, Edinburgh.

Herne, A 1991 'The flint assemblage', in Longworth, I, Herne, A, Varndell, G \& Needham, S (edS) Excavations at Grimes Graves, Norfolk 1972-6. Fascicule 3, Shaft X: Bronze Age Flint, Chalk and Metal Working, 21-93. British Museum Press, London.

Hodder, I 1979 'Economic and social stress and material culture patterning', Am Antiquity 44(3), 446-54.

Humble, J forthcoming 'Flint and stone artefacts', in Parry, S J (ed) Raunds Area Survey. An archaeological study of the landscape of Raunds, Northamptonshire 1985-92.

Jeppesen, J 1984 'Funktionsbestemmelse af flintredskaber. Slidsporsanalyse af skrabere fra Sarup', Kuml 1982/3, 31-60.

Juel Jensen, H 1988 'Microdenticulates in the Danish Stone Age: a functional puzzle', Oxford (=Br Archaeol Rep, International Ser, 411), 231-52.

Juel Jensen, H 1994 Flint Tools and Plant Working. Hidden Traces of Stone Age Technology. A use wear study of some Danish Mesolithic and TRB implements. Aarhus University Press, Aarhus.

Keeley, L H 1982 'Hafting and re-tooling: effects of the archaeological record', Am Antiquity 47(4), 798-809.

Knight, J 1991 'Vein quartz', Lithics 12, $37-56$.

Knutsson, K 1978 'Skrapor och skrapning. Ett exempel på artefakt-och boplatsanalys', TOR, XVII, 1975-7, 19-62.

Knutsson, K 1988 Making and using stone tools. The analysis of the lithic assemblages from Middle Neolithic sites with flint in Västerbotten, northern Sweden. Aun, 11. Archaeological Studies, Uppsala University Institute of North European Archaeology, Uppsala.

Manby, T G 1974 Grooved Ware Sites in Yorkshire and the North of England. Oxford $(=\mathrm{Br}$ Archaeol Rep, Br Ser, 9).

Mann, L M 1918 'The prehistoric and early use of pitchstone and obsidian', Proc Soc Antiq Scot LII, 140-9.

Marshall, D N 1978 'Excavations at Auchategan, Glendaruel, Argyll', Proc Soc Antiq Scot 109, 36-74.

Megaw, J V S \& Simpson, D DA 1979 Introduction to British Prehistory. From the Arrival of Homo sapiens to the Claudian Invasian. Leicester University Press, Leicester.

Mercer, J 1968 'Stone tools from a washing-limit deposit of the highest post-glacial 
transgression, Lealt Bay, Isle of Jura', Proc Soc Antiq Scot 100, 1-46.

Mercer, J 1971 'A regression-time stoneworkers' camp, $33 \mathrm{ft} \mathrm{OD,} \mathrm{Lussa} \mathrm{River,} \mathrm{Isle} \mathrm{of} \mathrm{Jura',} \mathrm{Proc}$ Soc Antiq Scot 103, 1-32.

Mercer, J 1972 'Microlithic and Bronze Age camps, 75-26 ft OD, N Carn, Isle of Jura', Proc Soc Antiq Scot 104, 1-22.

Mykura, W 1976 Orkney and Shetland. British Regional Geology 1. Natural Environment Research Council, Institute of Geological Sciences/Her Majesty's Stationery Office, Edinburgh.

Ness, J, \& Ward, T 2001 Pitchstone Seminar, held 30 September 2000. Report. Biggar Museum Trust, Biggar.

Pollard, T 1997 'Excavation of a Neolithic settlement and ritual complex at Beckton Farm, Lockerbie, Dumfries \& Galloway', Proc Soc Antiq Scot 127, 6-121.

Powell, B W 1965 'An aboriginal quartz quarry at Samp Mortar Reservoir, Fairfield, Connecticut', Bull Archeol Soc New Jersey, 22 (http://www.bwpowell.com/archeology/ sampmortar/mortar.html).

Rees, S 1986 'Stone implements and artefacts', in Whittle, A (ed) Scord of Brouster. An Early Agricultural Settlement on Shetland. Oxford University Committee for Archaeology Monograph 9, 75-91, Oxford.

Renfrew, C 1977 'Alternative models for exchange and spatial distribution', in Earle, T K, \& Ericson, J E (eds) Exchange Systems in Prehistory, 71-90. Academic Press, New York.

Rennie, E 1977 'Dunloskin, huts', Discovery Excav Scot 1977, 6.

Russel-White, C J 1995 'The excavation of a Neolithic and Iron Age settlement at Wardend of Durris, Aberdeenshire', Proc Soc Antiq Scot 125, 9-28.

Sabine, K, \& Warren, G 2002 Balbridie Chipped Stone. Unpublished report.

Saville, A 1981 Grimes Graves, Norfolk. Excavations 1971-2, Volume II: The Flint Assemblage. Department of Environment Archaeological Reports 11, London.

Saville, A 1994 'Exploitation of lithic resources for stone tools in earlier prehistoric Scotland', in Ashton, N, \& David, A (eds) Stories in Stone, 57-70. Lithic Studies Society Occasional Paper 4, London.
Saville, A 1995 'GB 20: Den of Boddam near Peterhead, Grampian Region, Scotland. GB 21: Skelmuir Hill, Grampian Region, Scotland. Prehistoric exploitation of flint from the Buchan Ridge Gravels, Grampian region, north-east Scotland', Archaeologia Polona 33, $353-68$.

Saville, A \& Ballin, T B 2001 'Quartz technology in Scottish prehistory', Lithics 21, 45-51.

Thorsberg, K 1986 'Myten om eggvinklen', Fjölnir, $5.1,1986,45-51$.

Tolan-Smith, C 2001 The Caves of Mid Argyll. An Archaeology of Human Use. Society of Antiquaries of Scotland Monograph Series 20, Edinburgh.

Warren, $\mathrm{G}$ forthcoming 'Stone tool industries of the earlier neolithic in eastern Scotland', Scott Archaeol J.

Warren, G no date Hawkhill, Angus: Chipped Stone. Unpublished report.

Whittle, A 1986 Scord of Brouster. An Early Agricultural Settlement on Shetland. Oxford University Committee for Archaeology Monograph 9, Oxford.

Wickham-Jones, C J 1990 Rùm. Mesolithic and Later Sites at Kinloch. Excavations 1984-86. Society of Antiquaries of Scotland Monograph Series 7, Edinburgh.

Wickham-Jones, C J 1997 'The flaked stone', in Masters, L 'The excavation and restoration of the Camster Long chambered cairn, Caithness, Highland, 1967-80', Proc Soc Antiq Scot 127, $123-83$.

Wickham-Jones, C J, \& MacKenzie, J R 1996 'An unusual lithic assemblage from Lunanhead, Angus', Proc Soc Antiq Scot 126, 1-16.

Wickham-Jones, C J, Brown, M M, Cowie, T G, Gallagher, D B, \& Ritchie, J N G 1982

'Excavations at Druim Arstail, Oronsay, 191112', Glasgow Archaeol J 9, 18-30.

Wiessner, P 1983 'Style and social information in Kalahari San projectile points', Am Antiquity 48 (2), 225-76.

Williams Thorpe, O, \& Thorpe, R S 1984 'The distribution and sources of archaeological pitchstone in Britain', J Archaeol Sci 11, 1-34.

Woodland, A W 1979 Geological Map of the United Kingdom North (North of National Grid Line $500 \mathrm{~km} \mathrm{~N}$ ), 3rd Edn. Institute of Geological Sciences, Southampton. 